Article

\title{
Regional Lithological Mapping Using ASTER-TIR Data: Case Study for the Tibetan Plateau and the Surrounding Area
}

\author{
Yoshiki Ninomiya ${ }^{1, *}$ and Bihong Fu ${ }^{2}$ \\ 1 Geological Survey of Japan, National Institute of Advanced Industrial Science and Technology, \\ Tsukuba 3058567, Japan \\ 2 Institute of Remote Sensing and Digital Earth, Chinese Academy of Sciences, Beijing 100094, China; \\ fubh@radi.ac.cn \\ * Correspondence: yoshiki.ninomiya@aist.go.jp; Tel.: +81-29-861-3975
}

Academic Editors: Kevin Tansey and Stephen Grebby

Received: 9 May 2016; Accepted: 23 August 2016; Published: 2 September 2016

\begin{abstract}
The mineralogical indices the Quartz Index (QI), Carbonate Index (CI) and Mafic Index (MI) for ASTER multispectral thermal infrared (TIR) data were applied to various geological materials for regional lithological mapping on the Tibetan Plateau. Many lithological and structural features are not currently well understood in the central Tibetan Plateau, including the distribution of mafic-ultramafic rocks related to the suture zones, the quartzose and carbonate sedimentary rocks accreted to the Eurasian continent, and sulfate layers related to the Tethys and neo-Tethys geological setting. These rock types can now be mapped with the interpretation of the processed ASTER TIR images described in this paper. A methodology is described for the processing of ASTER TIR data applied to a very wide region of the Tibetan Plateau. The geometrical and radiometric performance of the processed images is discussed, and the advantages of using ortho-rectified data are shown. The challenges of using ASTER data with a small footprint in addition to selecting an appropriate subset of scenes are also examined. ASTER scenes possess a narrow swath width when compared to LANDSAT data (60 km vs. $185 \mathrm{~km}$, respectively). Furthermore, the ASTER data archive is vast, consisting of approximately three million images. These details can present an added level of complexity during an image processing workflow. Finally, geological interpretations made on the maps of the indices are compared with prior geological field studies. The results from the investigations suggest that the indices perform well in the classification of quartzose rocks based on the carbonate and mafic mineral content, in addition to the granitic rocks based on the feldspar content.
\end{abstract}

Keywords: ASTER; TIR; geology; mineralogy; suture zone; quartz; feldspars; silicates; carbonates; sulfates; granitic rocks; felsic; ultramafic; mapping

\section{Introduction}

Spectroscopic studies of inorganic materials in the thermal infrared (TIR) region $(8-12 \mu \mathrm{m})[1,2]$ have demonstrated strong absorption features caused by the stretching vibrations of the $\mathrm{Si}-\mathrm{O}$ bonds in silicate minerals, the major components of the terrestrial surface, whereas the Si-O bonds do not cause any prominent spectral features in the visible and near-infrared (VNIR) region of the spectrum $(0.4-2.5 \mu \mathrm{m})$ [3]. Studies carried out during the Apollo missions to the Moon in the 1960s confirmed relationships between the TIR spectral features and the geology of the lunar surface composition (e.g., References $[4,5])$. For example, it was observed that the emissivity minima due to $\mathrm{Si}-\mathrm{O}$ stretching vibrations (i.e., reststrahlen bands) moved to longer wavelengths as the composition of the target igneous rocks changed from felsic to ultramafic [6]. 
The airborne and satellite remote sensing systems were developed after the results of the spectroscopic studies shown above. They demonstrated the capability of detecting rock composition, despite the radiometric, spectral and spatial resolutions being much worse when compared to a modern system such as ASTER. For example, an airborne scanner with two detector elements could distinguish quartz sandstone from nonsilicate surface materials [7]. Additionally, the infrared interferometric spectrometer onboard the Nimbus-4 satellite derived a global surface emissivity map at $9 \mu \mathrm{m}$, which discovered the significantly low emissivities over arid areas due to quartz, even with a quite low spatial resolution $(\sim 100 \mathrm{~km})$ [8].

The airborne Thermal Infrared Multispectral Scanner called TIMS was the first modern thermal infrared remote sensing system with resolutions adequate for geological applications (e.g., References [9,10]). TIMS and similar airborne systems (e.g., Reference [11]) confirmed their capabilities of detecting the systematic shift of the reststrahlen bands in the silicate rocks and minerals.

The Advanced Spaceborne Thermal Emission and Reflection Radiometer (ASTER) sensor developed by the Japanese government was launched onboard Terra, the first of NASA's Earth Observing System (EOS) series of satellites, in December 1999 [12]. It is composed of three subsystems: (1) the VNIR subsystem observing the visible to near-infrared region (three bands between 0.5 and $0.9 \mu \mathrm{m}, 15 \mathrm{~m}$ resolution with a stereoscopic capability for the NIR band); (2) the SWIR subsystem observing the shortwave infrared region (six bands between 1.6 and $2.5 \mu \mathrm{m}, 30 \mathrm{~m}$ resolution); and (3) the TIR subsystem observing the thermal infrared region (five bands between 8 and $12 \mu \mathrm{m}, 90 \mathrm{~m}$ resolution, NE $\Delta \mathrm{T}<0.3 \mathrm{~K}$ at $300 \mathrm{~K}$ ), respectively. The spatial coverage of an ASTER image at the surface is approximately $60 \times 60 \mathrm{~km}$.

The authors have proposed mineralogical indices defined with the ratioing approach of the ASTER data for detecting lithology or mineralogy [13-17]. Especially the Quartz Index (QI), Carbonate Index (CI) and Mafic Index (MI) defined for the ASTER-TIR data are finely analyzed theoretically and practically, and the performance of the indices in extracting geological information is confirmed [14]. Many studies have applied the indices (e.g., References [13-19]) and other workers have proved the usefulness and the stability of the indices in the local geological case studies (e.g., References [20-29]). Despite ASTER radiance registered at the sensor data without atmospheric corrections being adopted for the calculation of the indices, the recognized scene dependency is quite weak if the atmospherically well-conditioned data are selected [17].

One of the main goals of this project is the mapping of large-scale structure and lithology. We therefore commenced research for regional-scale mapping covering a wide area with the spectral indices. Considering the relatively narrow spatial coverage of each ASTER data compared to that of LANDSAT, many scenes need to be mosaicked for mapping a wide area. Additionally, the ASTER data archive is vast and constantly expanding due to the collection of data over the past 16 years that ASTER has been in operation. This makes it difficult to locate suitable scenes when mapping a region of interest. To save time and labor, the selection of well-conditioned data, in addition to prioritizing the selected data and calculating the indices and mosaicking the imagery, was followed [30].

In this paper, we present the regional maps of the indices covering the region of the central Tibetan Plateau and the surrounding area, after summarizing the geology of the study area and introducing the methodology of calculating the indices and producing the regional maps. In total, 386 ASTER products are selected from a database of more than 10,000 scenes to produce the regional maps. The characteristics of the indices for typical geological and the other materials and the radiometric and geometrical performances of the produced maps are discussed. Finally, geological interpretations are made in association with the maps.

\section{Materials and Methods}

\subsection{Study Area}

The study area is the central part of the Tibetan Plateau and the surrounding area, bounded by latitude $28^{\circ} \mathrm{N}$ to $37^{\circ} \mathrm{N}$ and longitude $84^{\circ} \mathrm{E}$ to $90^{\circ} \mathrm{E}$. The previous studies (e.g., [31,32]) have revealed 
that the geology of the Tibetan Plateau involves multiple terranes, suture zones containing ophiolites and ophiolitic mélanges, high-P metamorphic belts, magmatic arcs, and accretionary prism complexes that largely developed during the Paleozoic-Mesozoic Eras.

Knowledge of the pre-Cenozoic lithospheric architecture of Tibet is critical for providing initial conditions for models of Tibetan Plateau formation, for establishing strain markers to quantify Cenozoic deformation, and for the development of hypotheses to explain heterogeneous tectonism related to the Cenozoic Indo-Asian collision. From northeast to southwest, Tibet is comprised of the Altyn Tagh-East Kunlun-Qilian, Songpan-Ganzi, Qiangtang, Lhasa and Himalayan terranes, which are separated by east-striking suture zones of Paleozoic to Mesozoic age (Figure 1). Many researchers [31,32] proposed that the formation and evolution of the Tibetan Plateau have been intrinsically related to those of the eastern Tethys, recorded by the Longmu Co-Shuanghu ophiolite mélange zone, the Southern Qiangtang Paleozoic accretionary arc-basin system, the Bangong-Nujiang suture zone, and their associated, composite island arc-basin systems. The present-day Bangong-Shuanghu-Changning-Menglian suture system marks the final closure of the Tethyan Ocean. The Indus-Tsangbo Ocean opened as a back-arc basin in response to the southward subduction of the Tethyan Ocean lithosphere in the Middle Triassic. In addition, it closed as a result of the India-Asia collision at the end of Cretaceous, followed by the northward indention of the Indian plate that resulted in significant intra-continental deformation and plateau uplift in the Cenozoic. Cenozoic deformation mainly produced a crustal scale shear zone and décollement between the Precambrian basement and the cover sequences, regional thrust faults and folds, and strike-slip fault zones.

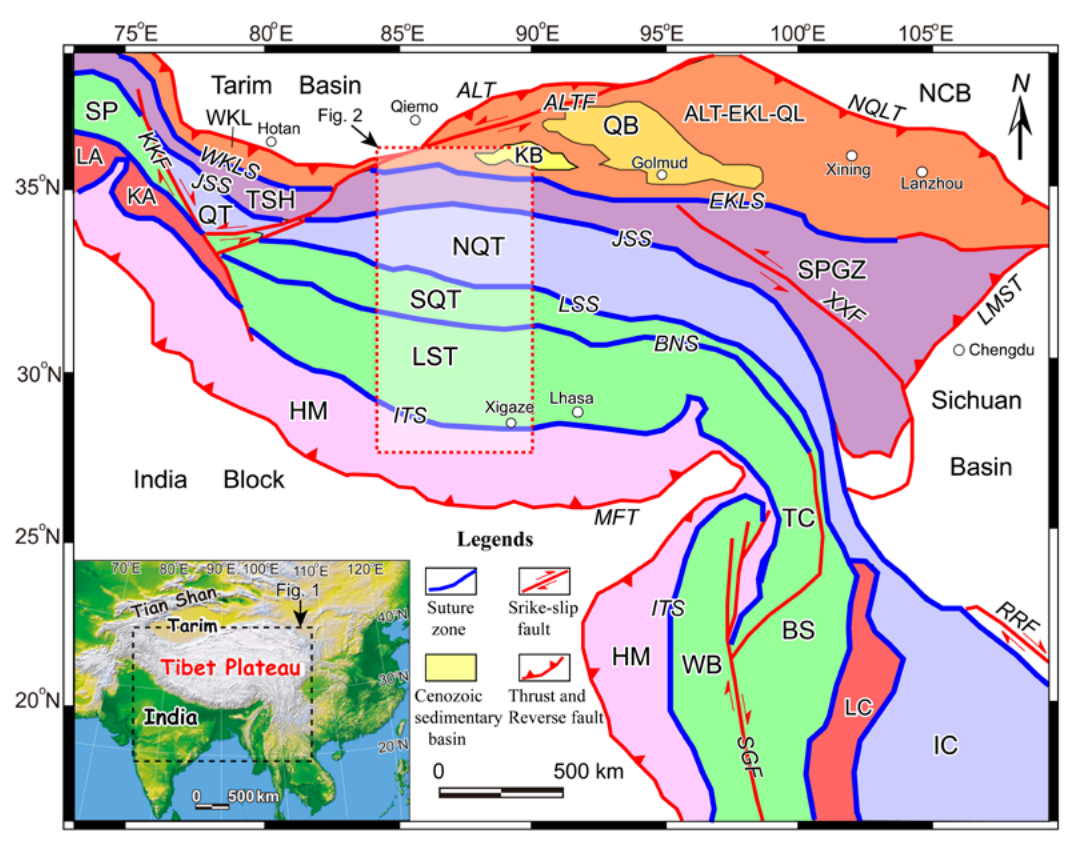

Figure 1. Simplified tectonic map of Tibet and surrounding region, showing the main suture zones in Tibet (modified from References [26-28]. Blocks and terranes: ALT-EKL-QL: Altyn Tagh-East Kunlun-Qilian terrane; BS: Baoshan terrane; HM: Himalayan terrane; IC: Indo-China block; KA: Kohistan Arc terrane; LA: Ladakh arc terrane; LC: Lincang-Sukhothai-Chanthaburi Arc terrane; LST: Lhasa terrane; NCB: North China Block; NQT: North Qiangtang terrane; QT: Qiangtang terrane; SP: South Pamir terrane; SPGZ: Songpan-Ganze terrane; SQT: South Qiangtang terrane; TC: Tengchong terrane; TSH: Tianshuihai terrane; WB: West Burma terrane; WKL: West Kunlun terrane. Suture zones: BNS: Bangong-Nujiang Suture; EKLS: East Kunlun Suture; ITS: Indus-Tsangbo Suture; JSS: Jinsha Suture; LSS: Longmu Tso-Shuanghu-Menglian-Inthanon Suture; WKLS: West Kunlun Suture. Basins: QB: Qaidam Basin; KB: Kumkol Basin. Faults: ALT: Altyn Tagh Thrust; ALTF: Altyn Tagh Fault; KKF: Karakorum Fault; LMST: Longmen Shan Thrust; MFT: Main Frontal Thrust; NQLT: North Qilian Thrust; RRF: Red River Fault; SGF: Sagaing Fault; XXF: Xianshui River-Xiaojiang Fault. The dashed red rectangle represents the study area. 
Figure 1 shows the tectonic setting of the Tibetan Plateau and the surrounding area, modified from the previous studies [33-35]. As shown in Figure 1, this study area is composed of the blocks of the Altyn Tagh-East Kunlun-Qilian terrane, Songpan-Ganzi terrane, North Qiangtang terrane, South Qiangtang terrane, Lhasa terrane and Himalayan terrane, from north to south. The most important geological features targeted in this study include the ophiolite belts appearing at the surface along the sutures of the blocks, the quartzose and carbonite sedimentary rocks deposited as the accretionary wedges associated with the subduction of the oceanic plate beneath the continental plate, the granitic rocks intruded with the island arc geological setting, and the distributions of the sulfate layers as the geological evidence of the neo-Tethys environment. The field geological studies so far (e.g., [36-43]) have revealed the distribution of the target lithological features at some limited local areas in the Tibetan Plateau. However, these terranes and suture zones are poorly characterized in central Tibet, with a $>1000-\mathrm{km}$-long and up to $500-\mathrm{km}$-wide tectonic belt, where the field geological surveys have not yet been accomplished well for most of the region because this area is remote and inaccessible (Figure 1).

The geological map at the scale of 1:1,500,000 is published [44] for the entire Tibetan Plateau region including the study area. Larger-scale geological maps are published at the limited locations, for example the geological map of the ophiolite zone at the scale of 1:200,000 in the middle segment of the Indus-Tsangbo suture zone [45].

\subsection{ASTER Data}

Since the launch of ASTER in December 1999, the VNIR and TIR subsystems have observed the earth for more than 16 years. This has far exceeded its original lifespan of five years. The SWIR subsystem stopped operation in 2008 due to over saturation and severe striping of the detector. Ownership of the ASTER data had been held by the Ministry of Economy, Trades and Industry (METI) of Japan and NASA, and the ASTER data were distributed by the Japan Space Systems (JSS) and the USGS Eros Data Center, respectively. It was necessary to pay a nominal fee to METI for ordering ASTER data products except for the freely distributed ASTER global digital elevation model (GDEM) products [46] until March 2016. In April 2016, a change in policy was announced [47]. As a result, all ASTER data products are available at no cost. Furthermore, the ASTER data distributor in Japan has changed from JSS to the National Institute of Advanced Industrial Science and Technology (AIST).

The data observed by the ASTER sensors (Level-0 data) are transmitted to ground stations, where the data for each scene is processed to generate the standard Level-1A data product which retains the raw data observed with the sensor. Until March 2016, the ASTER data product was generated and provided as described below. Each standard and semi-standard product of the ASTER data was generated as a Hierarchy Data Format (HDF) file. The standard Level-1B data product was generated automatically for all the Level-1A data satisfying a condition on the detected cloud coverage, as well as based on the user request, which apply the fundamental geometrical and radiometric corrections essential for most of the geoscience applications. Each pixel data in Level-1B is in the measure of radiance registered at the sensor [48-51]. The standard higher level Level-2B data products of physical parameters including the surface radiance data with the atmospheric corrections on Level-1B data (Level-2B01) $[52,53]$ and the surface emissivity data with the temperature separation processing on the TIR data of the Level-2B01 data (Level-2B04) [54] were generated on the basis of the user request. Also, the semi-standard Level-4 data product of the DEMs was generated from the along-track NIR stereo images (band 3N and 3B) with the downward- and backward-viewing telescopes [55]. The semi-standard Level-3A data product with the ortho-rectification processing had been provided by JSS, which includes the radiance registered at the sensor data equivalent to the one of the Level-1B product and the ASTER-driven DEM [56].

After April 2016, AIST supplies the ortho-rectified data products corresponding to Level-3A in the GeoTIFF files [57], and USGS supplies the data products including the ortho-rectified data of the radiance registered at the sensor (Level-1T) in the HDF files [58] freely to the public covering all over the world, in addition to the ASTER GDEM products already provided to public as described above. 
This study uses the ASTER products of radiance at the sensor (e.g., Level-1B, Level-3A). The DN of ASTER-TIR band $\mathrm{i}$ in the Level-1B or Level-3A data is linearly related to radiance registered at the sensor $\left(\mathrm{Wm}^{-2} \cdot \mathrm{sr}^{-1} \cdot \mu \mathrm{m}^{-1}\right)$ by [49]

$$
L_{\text {sen }}{ }^{i}=\operatorname{coef}^{i} \times\left(D N^{i}-1\right),
$$

where coef ${ }^{10}=0.006882$, coef $^{11}=0.006780$, coef $^{12}=0.006590$, coef $^{13}=0.005693$, and coef $^{14}=0.005225$.

Figure 2 shows a false color composite mosaic generated with the ASTER data used in this study annotated with typical geographical information in this study area. All images of the regional maps including Figure 2 are projected using zone 43 of the Universal Transverse Mercator (UTM). As the mosaic VNIR imaging is not the purpose of this study, only an automatic color balancing of the linear stretching in the histogram region covering "average $\mathrm{DN} \pm 3 \times \sigma^{\prime \prime}$ was applied, except for the southern part of the study area bounded by latitude $28^{\circ} \mathrm{N}$ to $30^{\circ} \mathrm{N}$, where the color balancing is carefully achieved manually.

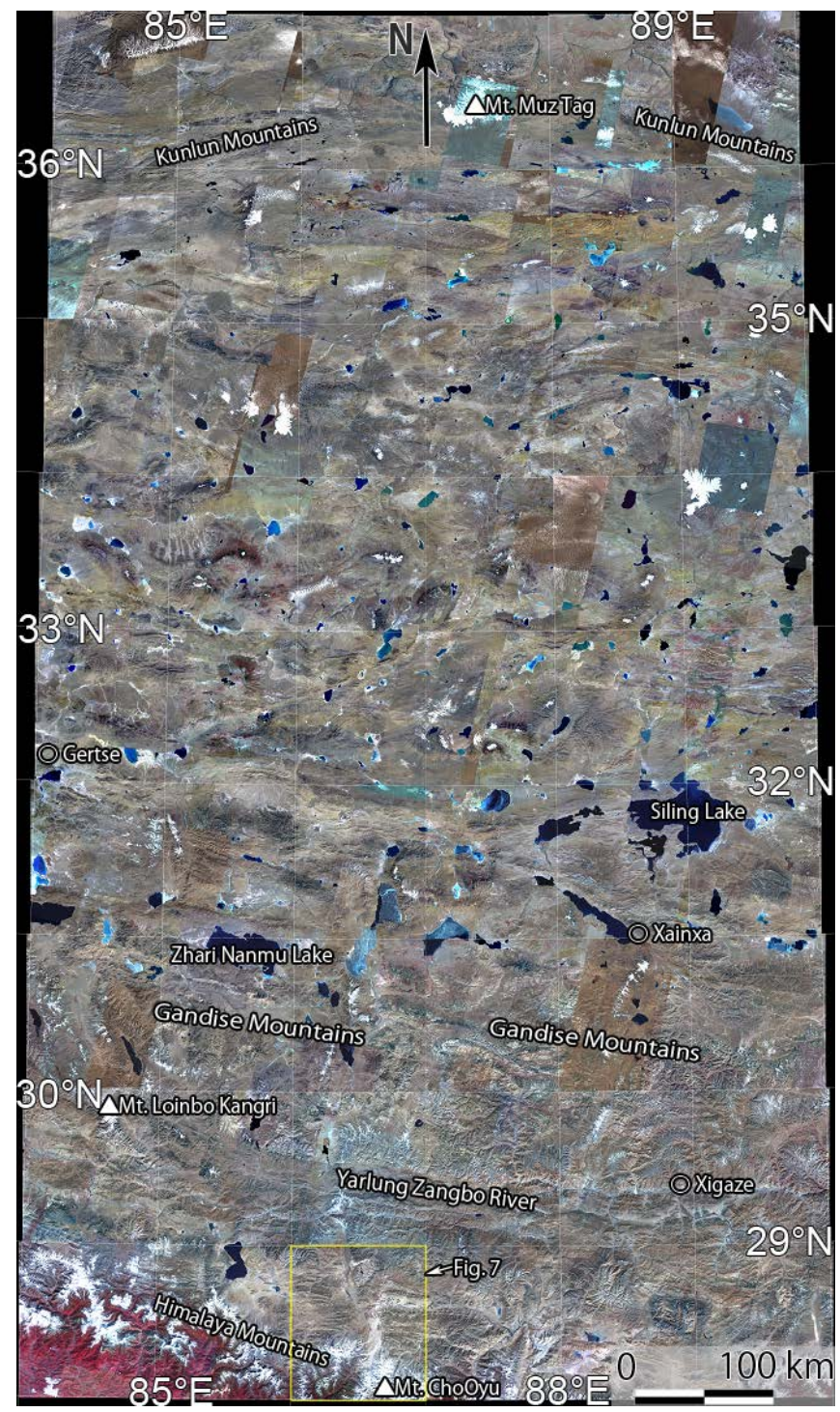

Figure 2. Mosaic VNIR false color image generated with the ASTER data used in this study, assigned as blue for band 1, green for band 2 and red for band 3 covering the study area bounded by latitude $28^{\circ} \mathrm{N}$ to $37^{\circ} \mathrm{N}$ and longitude $84^{\circ} \mathrm{E}$ to $90^{\circ} \mathrm{E}$, using a Universal Transverse Mercator (UTM) map projection. Geographical locations of some cities, mountains, etc., are shown. The yellow rectangle represents the area of Figure 7. 


\subsection{Mineralogical Indices for ASTER-TIR}

Based on analysis of the spectral properties for typical terrestrial rocks and minerals shown in Figure 3, the indices, QI, CI and MI were proposed [13]. After the precise analysis on the performance of the indices against the temperature and the atmospheric conditions as well as concerning the separation among the mineral types, the indices were defined [14,17] as described below.

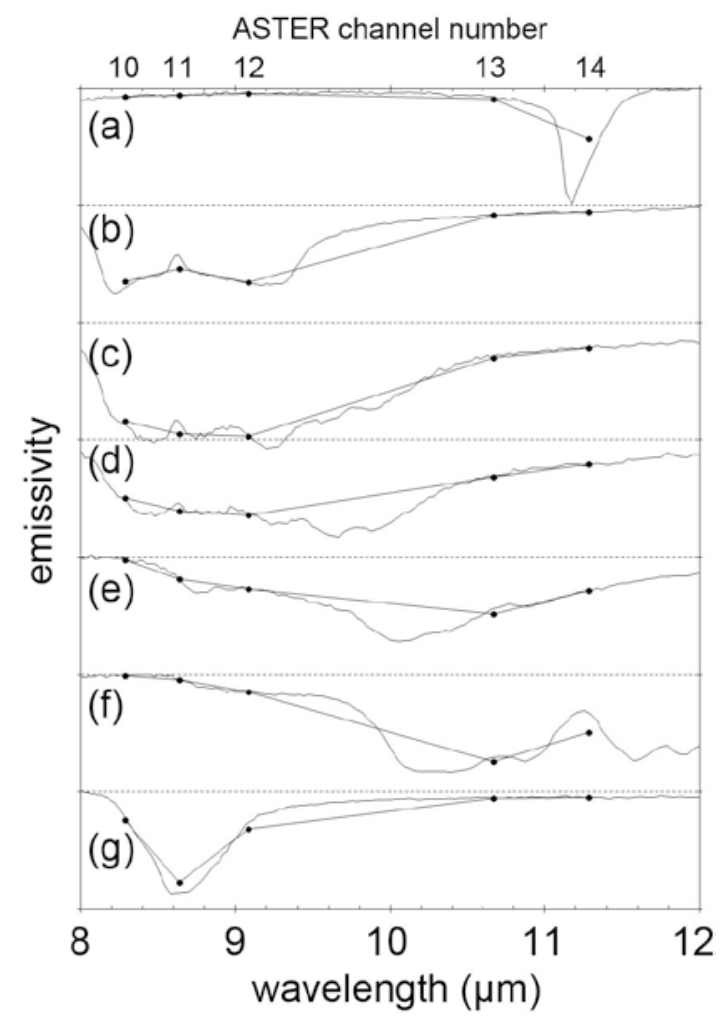

Figure 3. Emissivity spectra for common rock types (a) carbonate rock; (b) quartzose sedimentary rock; (c) felsic rock (granite); (d) intermediate rock (diorite); (e) mafic rock (gabbro); (f) ultramafic rock (dunite); (g) gypsum (modified after Ninomiya et al. [17]). Each tick in the $Y$ axis denotes 1.0/0.75 of emissivity except for $(\mathbf{b})$ where it denotes $1.0 / 0.5$ of emissivity.

To emphasize the specific spectral feature for quartz in the major rock-forming minerals, e.g., higher emissivity at the $8.6 \mu \mathrm{m}$ region (corresponding to ASTER band 11) compared to the emissivity at the 8.3 and $9.1 \mu \mathrm{m}$ regions (corresponding to ASTER band 10 and band 12, respectively) as shown in Figure 3b, QI was defined as [13]

$$
Q I=\frac{D_{11} \times D_{11}}{D_{10} \times D_{12}}
$$

where $D i$ represents ASTER band $i$. In this paper, we use radiance data without atmospheric corrections of ASTER Level-1B or Level-3A data. The DN value of each pixel in Level-1B or Level-3A data is linearly converted to radiance registered at the sensor $\left(\mathrm{Wm}^{-2} \cdot \mathrm{sr}^{-1} \cdot \mu \mathrm{m}^{-1}\right)$ with Equation (1). QI is expected to be high for crystallized quartz, and on the other hand, to be low for the common sulfates, typically gypsum because the spectral features for the sulfates in ASTER bands 10 to 12 are the opposite of quartz as recognized in the spectrum of gypsum shown in Figure $3 \mathrm{~g}$. Not as strong but similar as the sulfates, K-feldspars and Na-feldspars exhibit the opposite spectral features of quartz. If the rocks are rich in both quartz and feldspar, which often occurs in igneous rock, typically for the granitic rocks, QI is expected to be relatively low $[15,17,19,30]$. The spectral emissivity property of the rock type shown in Figure 3c supports this expectation. The mixture of quartz and feldspar does not generally occur in sedimentary rocks, which suggests high QI functions well as an indicator of 
quartz-rich sedimentary rocks. The previous studies have confirmed that high QI is a distinct indicator for quartz-rich sedimentary rocks $[14-19,21-23,26,29,30]$, and low QI is a distinct indicator primarily of sulfate minerals $[15-17,30]$ and secondarily of feldspar-rich silicate rocks $[15,17,19,30]$.

The spectral emissivity of carbonate rock which is composed of the two major carbonate-forming minerals on Earth, calcite and dolomite, is shown in Figure 3a. This indicates the absorption feature is only at the $11.3 \mu \mathrm{m}$ region (corresponding to ASTER band 11), and CI for ASTER TIR data was defined as [13]

$$
C I=\frac{D_{13}}{D_{14}}
$$

$\mathrm{CI}$ is expected to be high for calcite and dolomite. Prior studies have confirmed that a high CI signal is a good indicator for the presence of marine sedimentary rocks that are composed of calcite and/or dolomite [14-19,21,24,25]. It should be considered that the atmospheric anomalies such as the clouds and the mists can also cause relatively high CI as discussed in Section 4.1.

The spectral emissivity for silica and silicate rocks (typically igneous rocks), as shown in Figure $3 b, c, d, e, f$, demonstrates that the ratio of the emissivity at band 12 or the lower wavelengths to band 13 or the higher wavelengths increases as the chemical $\mathrm{SiO}_{2}$ content decreases (i.e., as the rock type changes from silicic, felsic to mafic). The ratio value indicates the medium value in the carbonates. To accomplish the separation of the carbonate rocks in the spectral features described above, MI was defined as [13]

$$
M I=\frac{D_{12}}{D_{13} \cdot C I^{3}}=\frac{D_{12} \cdot D_{14}{ }^{3}}{D_{13}{ }^{4}} .
$$

$\mathrm{MI}$ is expected to have an inverse correlation to the chemical $\mathrm{SiO}_{2}$ content in silicate rocks. It is expected to be high for ultramafic rocks, and to move systematically lower as the rock type changes to felsic, and to be quite low for silicic rocks. Similarly, it has been confirmed that high MI is a distinct indicator of ultramafic rocks [14-18,25-30]. Low MI is sensitive for high $\mathrm{SiO}_{2}$ content rocks with both crystallized and amorphous silica [14,17]. Considering QI is sensitive only for the crystallized quartz, the discrimination between crystallized and disordered quartzose rocks is possible using both QI and MI.

A theoretical analysis on the stability of the indices against the surface temperature and the atmospheric parameters indicated QI and MI are well stabilized against temperature if the atmospheric conditions are good, but CI exhibits a strong dependency on the surface temperature even in atmospherically good conditions [14]. The properties of the indices were confirmed by a practical analysis comparing the results applied to multi-temporal scenes observing a study area [14]. It then showed the effectiveness of the normalization processing of the brightness temperature at band 13 to a fixed temperature on improving the heavy dependency of $\mathrm{CI}$ to the surface temperature. The normalized radiance registered at the sensor at band $i$ was defined after the Planck function as $[14,17]$

$$
n L_{\text {sen }}^{i}=L_{\text {sen }}^{i} \times \frac{\exp \left\{\frac{\lambda^{13}}{\lambda^{i}} \cdot \ln \left(\frac{c_{1}}{\pi \cdot \lambda^{13^{5}} \times L^{13} s_{\text {sen }}}+1\right)\right\}-1}{\exp \left(\frac{c_{2}}{\lambda^{i} \times n T / \varepsilon_{a^{13}}}\right)-1}
$$

where the radiation constants are $c_{1}=3.742 \times 10^{8}\left(\mathrm{Wm}^{-2} \cdot \mu \mathrm{m}^{-4}\right)$ and $c_{2}=1.439 \times 10^{4}(\mu \mathrm{m} \cdot \mathrm{W}), \lambda^{i}$ is the center wavelength $(\mu \mathrm{m})$ of ASTER band $i$ (i.e., $\lambda^{10}=8.3, \lambda^{11}=8.65, \lambda^{12}=9.1, \lambda^{13}=10.6, \lambda^{14}=11.3$ ), $L_{\text {sen }}^{i}$ is the radiance registered at the sensor in band $i$ as shown in Equation (1), $\varepsilon_{a}{ }^{13}$ is the assumed emissivity in band $13, n T$ is the fixed temperature (K) to be normalized. In this study, $\varepsilon_{a}{ }^{13}$ is adopted as 1.0, and $n T$ is adopted as 300 . This normalization process of the radiance is equivalent to a type of temperature separation processing without atmospheric corrections. That is, as $n L_{\operatorname{sen}}{ }^{13}$ corresponds to the blackbody radiation of $300 \mathrm{~K}$ at $\lambda^{13}$, when $n L_{\operatorname{sen}}{ }^{i}$ (Equation (5)) is divided with the blackbody radiation of $300 \mathrm{~K}$ at $\lambda^{i}$, it becomes the emissivity with the constant unity value at band 13 .

In this paper, the indices QI, CI and MI are calculated on the normalized radiance registered at the sensor data (Equation (5)) for the ASTER Level-1B or Level-3A data. One of the reasons for using 
radiance registered at the sensor data (e.g., Level-1B and Level-3A) is the higher availability compared to the emissivity data (e.g., Level-2B04). Another reason is the higher geometrical accuracy in the ortho-rectified image available for the radiance registered at the sensor data (e.g., Level-3A), which is discussed in detail in Section 4.2. The Level-2B04 emissivity data are partially applied just for the purpose of the comparison with the Level-1B or Level-3A data within a part of the study area.

\subsection{Regional Mapping}

The main goal of geological remote sensing requires the mapping of regions containing large-scale structure and lithology and this necessitates the mosaicking of large numbers of satellite scenes. The coverage of one ASTER scene corresponds to approximately $60 \mathrm{~km} \times 60 \mathrm{~km}$ on the ground. This is much smaller compared to LANDSAT-TM, which has ground coverage of approximately $185 \mathrm{~km} \times 170 \mathrm{~km}$. Therefore, the use of ASTER data for geological remote sensing requires the downloading and mosaicking of large numbers of scenes which can become unwieldy. On the other hand, the ASTER data archive is vast and has been actively collecting data for the past 16 years. The procedures to achieve the effective regional lithological mapping with the ASTER mineralogical indices are described below.

Firstly, the browse images of the ASTER data covering the required areas are checked before downloading. In this study, we had obtained ASTER Level-1B products from the JSS site which had closed because of the change in the ASTER data distribution policy which had been announced on April 2016 as described in Section 2.2. An alternative method for obtaining ASTER data is to check the browse images and submit an order at the sites of the new distributors (AIST and USGS) [53,54].

The next step is to calculate the indices (i.e., QI, CI and MI) for the respective data, and carefully check the images of the VNIR data and the indices manually. The CI index images should be checked carefully as they can be heavily affected by the atmospheric water content and as a result should be omitted as useless data. During the course of the checking, the priority ranking of each ASTER data is determined, and the mosaic images of the indices covering the area of interest are produced as the regional maps.

In the case of this study, we produce the mosaic images mapped for every $1^{\circ} \times 1^{\circ}$ region of the Earth surface (hereinafter, we call the region as "tile"), and then joined them together to produce the regional maps covering the entire study area with 54 tiles in total.

More than 10,000 ASTER scenes in archive covering the study area were checked with the browse images, and greater than 5000 Level-1B images were downloaded. The best 380 Level-1B products were selected to produce the regional maps covering the entire study area.

For the purpose of heightening the value of the geometrical positioning accuracy in the regional maps, each of the Level-1B products constructing the mosaic image is replaced with the Level-3A product of the same ASTER observation. However, the regional maps with the replaced Level-3A products do not cover a part of the area because the coverage of the Level-3A product is a little bit narrower than that of the Level-1B product to ensure the geometrical accuracy. The original Level-1B products are again utilized for the area not covered with the Level-3A products. Finally, the regional maps are consisting of the 380 Level-3A products together with the six Level-1B products. In total, the 386 ASTER image products are utilized for composing the regional maps as summarized in Table A1.

\section{Results}

Figure 4 shows the mosaic color composite image of QI, CI and MI with a linear contrast stretch applied of 0.97-1.055 (QI; Red), 1.005-1.055 (CI; Green), and 0.79-0.95 (MI; Blue) with the ASTER Level-3A products. Two small areas are not covered due to reasons explained in an earlier section. For those areas not covered by the Level-3A products as indicated in Figure 4 with blue polygons, the Level-1B products are alternatively utilized. Annotations have been added using points, lines and rectangles, as shown in Figure 4, indicating the locations which are discussed in the next chapter. Grayscale images with the linear contrast stretches for QI (0.95-1.1), CI (1.005-1.055), and MI (0.75-0.98) 
were produced using the same ASTER dataset as in Figure 4, as shown in Figure 5. The granule ID, observation date and location at the scene center of the ASTER data products consisting of the regional maps (Figures 4 and 5) are summarized in Table A1, which will be useful in reproducing the results shown here.

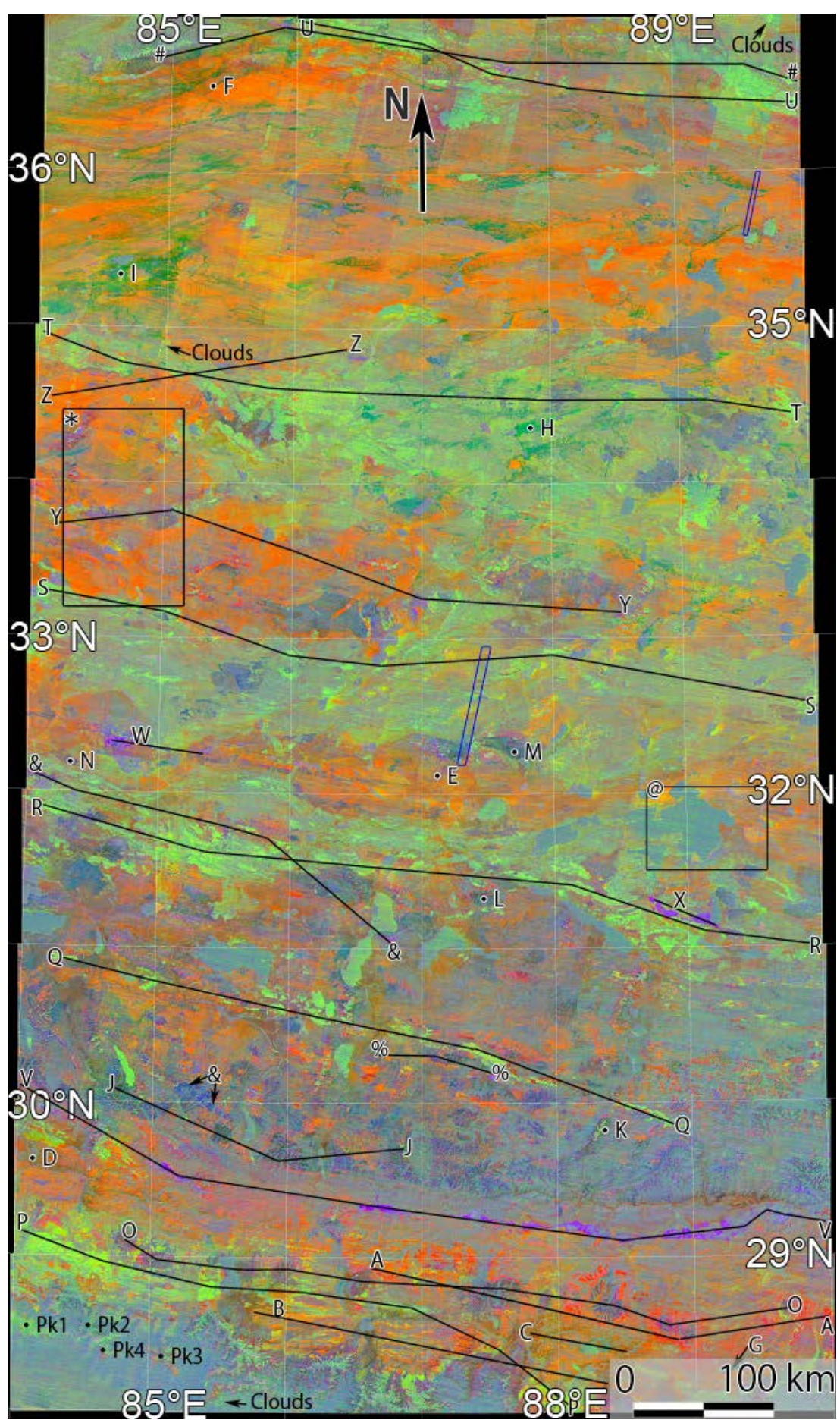

Figure 4. Mosaic color composite image of QI, CI and MI with a linear contrast stretch of 0.97-1.055 (QI; Red), 1.005-1.055 (CI; Green) and 0.79-0.95 (MI; Blue), with ASTER Level-3A products. The areas bounded by the blue polygons were mapped with Level-1B products when Level-3A products were not available. The annotations indicate the locations discussed in the text. The extent of the study area and the map projection are described in the caption in Figure 2. 


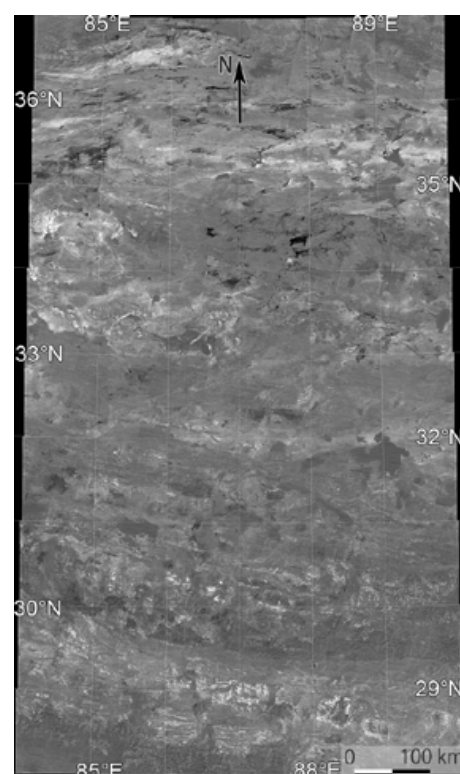

(a)

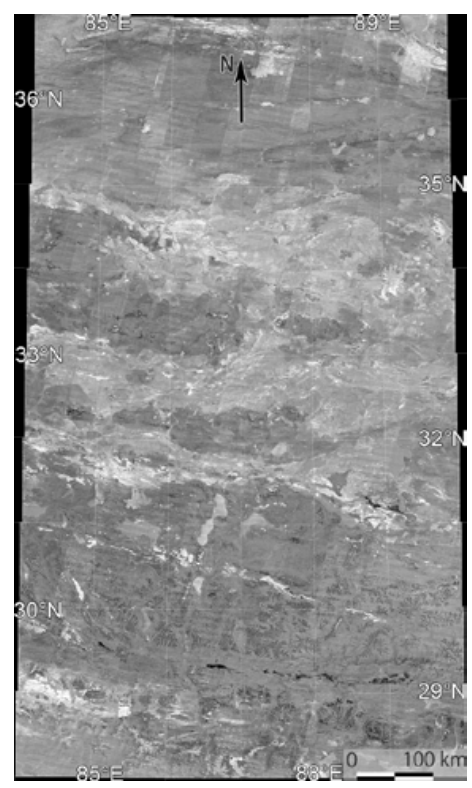

(b)

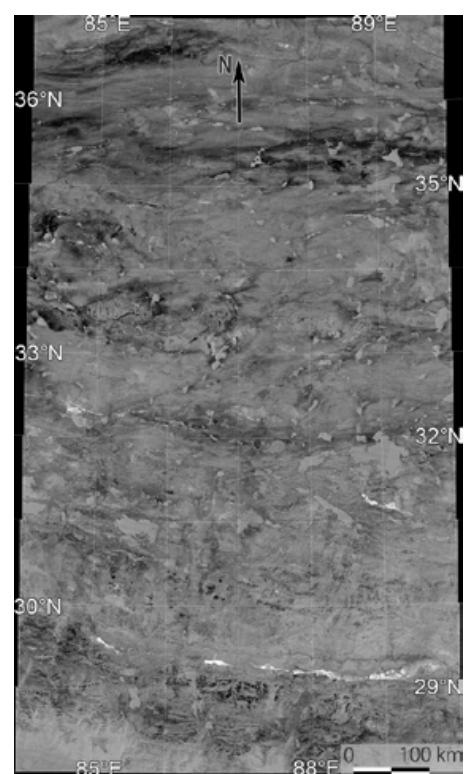

(c)

Figure 5. Grayscale image of the indices (a) QI with a linear contrast stretch of the histogram region 0.95 to 1.1 ; (b) CI with a linear contrast stretch of the histogram region 1.005 to 1.055; and (c) MI with a linear contrast stretch of the histogram region 0.75 to 0.98 , produced using the same ASTER dataset of Figure 4 covering the study area. The extent of the study area and the map projection are described in the caption in Figure 2.

To assist readers in locating details of the regional maps, the un-annotated, higher-resolution version of the VNIR false color image (Figure 2), the color composite image of the indices (Figure 4), and the grayscale images of QI (Figure 5a), CI (Figure 5b) and MI (Figure 5c) are presented in the Figures A1-A5. For the interactive display with the geographical information and DEM that will achieve further convenience to the readers, the color composite image of the indices (Figure 4) is converted to a Google Earth compatible KMZ file as presented in the Supplementary Figure S1.

\section{Discussion}

\subsection{Properties of Indices for Geological and Other Materials}

Many kinds of geological and the other materials are characterized with the indices. To avoid erroneous attention to the colors appearing in the composite image of the indices (Figure 4) for the targets without intensive features in each index (QI, CI or MI; Figure 5), the combined use of the grayscale and the color index images (Figures 4 and 5) is essential. Also, to distinguish the geological materials from the other materials (e.g., cloud, vegetation, snow, ice and water) in the images of indices (Figures 4 and 5), it is important to make interpretations referring to the VNIR false color image (Figure 2). In the discussions below, the location of the target is indicated with the annotations in Figure 4. The colors indicated in the discussion are of the composite index image (Figure 4).

High QI (>1.05) is a distinct indicator of quartz-rich/feldspar-poor rocks, usually quartzose sedimentary rocks [14-17], which are widely distributed in the study area as the whitish pixels in the QI image (Figure 5a). Looking at the details, there are several types in the high-QI rocks. The high-QI rock bodies along line " $\mathrm{A}$ " show relatively low $\mathrm{CI}(<1.02)$, whereas most of the others in the more northern part and the ones along line " $\mathrm{B}$ " show intermediate $\mathrm{CI}(>1.02)$ (Figure 5a,b). The former look pure reddish and the latter look yellowish-red (Figure 4). The differences of CI in the high-QI rocks can be reflecting the content of the carbonates in the quartzose rocks.

Taking notice of the relationship between QI and MI, since MI is designed inversely correlating to the $\mathrm{SiO}_{2}$ content in the silicate rocks, quartz with $100 \% \mathrm{SiO}_{2}$ content indicates low MI. Specifically, 
high-QI ( $>1.05)$ rocks simultaneously have low MI $(<0.80)$ (Figure 5a,c) in essence, as expected with the spectral property of quartz (Figure 3a). However, high-QI (>1.05) rocks together with intermediate MI $(>0.82)$ are often observed in and around the distribution area of the high-QI/low-CI rocks described above, especially along line " $\mathrm{A}$ ". These rocks are expected to be high in quartz content, coexisting with silicate minerals except feldspars. They are usually distributed around metamorphic domes in the north Himalayan metamorphic belt [38] as discussed later. This type of rock looks pure red to purplish-red (Figure 4).

In addition, there are some bodies of intermediate QI (1.02 to 1.04) together with low $\mathrm{MI}(<0.80)$, for example the ones along line " $\mathrm{C}$ " and around points " $\mathrm{D}$ ", " $\mathrm{E}$ " and " $\mathrm{F}$ " (Figure 5a,c). Most of the bodies are in the fluvial deposits, as recognized with the VNIR image (Figure 2), and can be non-crystallized, silica-rich deposits in which the spectral features of quartz in the ASTER band 10 to band 12 region (Figure $3 \mathrm{~b}$ ) are lost with the weathering processes. These materials look mixed dark-reddish (Figure 4). Also, the mixture of quartzose and sulfatic deposits can cause the characteristics of intermediate QI with low MI, which is usual in the northern part of the study area as the sulfate layers are often interbedded within the quartzose layers, as described below.

Low QI $(<0.98)$ is a distinct indicator for the common sulfate minerals (typically gypsum) [15-17] represented as the blackish pixels in Figure 5a. These rocks and deposits, for example the ones around the points " $\mathrm{G}$ ", " $\mathrm{H}$ " and "I", look deep greenish (Figure 4). We can find the bodies denoting the deep greenish color widely in the northern $\left(>33^{\circ} \mathrm{N}\right)$ part of the study area, often interbedded within the high-QI quartzose layers, which can be the sulfate layers accumulated in the neo-Tethys geological setting. Not as strong as sulfates, feldspar-rich rocks are typically a part of the granitic rocks and also show low QI $[15,17,19]$. The bodies around line "J" and point " $\mathrm{K}$ " in the Gandise Mountains (annotated in Figure 2), as well as the bodies around points " $\mathrm{L}$ ", " $\mathrm{M}$ " and " $\mathrm{N}$ ", are the examples of the rock type with a dark bluish-green color (Figure 4).

Several types of intrusive rocks can be discriminated by the combined analysis of the indices with the unique paternal texture information reflecting the geomorphological features of dissection and shape (Figures 4 and 5). One type is the feldspar-rich granitic rock described above. Gabbroic or basaltic rocks are also detectable, with the deep bluish color (Figure 4) reflecting the characteristics of relatively high MI $(\approx 0.90)$ and relatively low QI and CI (Figure 5$)[15,17]$, typically the rock body pointed out as " $\$$ ". Another type is granitic rock related to the north Himalayan metamorphic domes [21,36-38]. The domes are the granitic bodies intruding to the accretionary wedges of the south Tibetan detachment system [36], which looks like a dark pinkish-purple color with a unique texture and shape (Figure 4 ) along line " $\mathrm{O}$ ". Figure 4 suggests that the metamorphic domes are closely associated with the high-QI $(>1.05) /$ low-CI $(<1.02)$ rocks and the high-QI $(>1.05) /$ intermediate-MI (0.82 to 0.86$)$ rocks along line " $\mathrm{A}$ " discussed earlier in this section. According to the previous study [36], the high-QI $(>1.05) /$ low-CI $(<1.02)$ rocks can be linked to low-grade metamorphosed sediments and the high-QI ( $>1.05)$ /intermediate-MI ( 0.82 to 0.86$)$ ones to higher-grade ones. A more detailed analysis of the indices related to the metamorphic domes with reference to the published articles is presented later in Section 4.3.

High CI $(>1.05)$ is a distinct indicator of the common carbonate minerals, calcite and dolomite [14-17]. The high-CI rocks are widely distributed in the study area with the NWW trending, where the ones around lines " $\mathrm{P}$ ", "Q", " $\mathrm{R}$ ", " $\mathrm{S}$ ", “ $\mathrm{T}$ " and " $\mathrm{U}$ " are especially prominent (Figure $5 b$ ). They look light greenish in color (Figure 4). It should be noted the atmospheric water bodies (typically clouds and mist) also indicate high CI and look light greenish, similar to the carbonate minerals [14-17], as described later.

According to the definition of MI (Equation (4)), high MI (>0.92) is a distinct indicator of the ultramafic rocks with a quite low $\mathrm{SiO}_{2}$ content $(<40 \%)$ [14-17]. High-MI bodies are distributed widely in the study area, prominently in the southern part (Figure 5c). They look light purplish in color (Figure 4). The ophiolitic ultramafic rocks represent ancient remnants of the oceanic lithosphere and underlying upper mantle, which have appeared in the surface suture zones during the course of tectonic activities, especially in the subduction of the oceanic plate beneath the continental plate. 
The most prominent high-MI rocks appear along line "V" (Figures 4 and 5c), which is related to the Indus-Tsangbo Suture (Figure 1). The high-MI rocks around lines " $\mathrm{W}$ " and " $\mathrm{X}$ " are known as related to the Bangong-Nujiang Suture (Figure 1). The ultramafic exposures related to the other sutures in this study area, i.e., the Longmu Tso-Shuanghu-Menglian-Inthanon, the Jinsha and the East Kunlun suture zones (Figure 1), are not well studied. There are the other high-MI bodies, for example the ones around lines " $Y$ ", " $Z$ " and "\#". Additionally, the ones around lines "\%" and " $\&$ " are located in the northern and the southern part of the Lhasa terrane (Figure 1), respectively. The ultramafic rocks also indicate low CI $(<1.02)$ (Figure $5 b)$, which is another prominent feature in the indices other than high MI (>0.92). Further analysis on the ultramafic rocks with reference to the published articles is shown later in Section 4.3.

Some of the high-MI bodies, for example in and around the rectangle regions "@" and "**, are in the lacustrine deposits. The possible origin is the eroded mafic-ultramafic materials from the ophiolite carried downstream, overflowing from the lake [18]. Another possible origin of the high-MI signal is the existence of the chloride materials according to the evaporation processes in the deposits, as a part of the chloride materials is known to indicate high MI [17]. Further studies are necessary to confirm, however, that chlorides can be discriminated with mafic-ultramafic minerals using the feature of relatively high measures in all three indices [17].

Considering the characteristics appearing in the indices discussed above, a thematic map is produced by coloring the pixels, satisfying given conditions on the indices, as shown in Figure 6 . As described above, high QI has been confirmed to be a distinct indicator for high-quartz/low-feldspar sedimentary rocks $[14-19,21-23,26,29,30]$, but this study presents the first attempt to classify rock bodies within the high QI. The high-QI $(>1.05)$ bodies are divided into three classes with the conditions on CI and MI. The first class is for low MI $(<0.80) /$ medium CI $(>1.02)$, the second class is for low MI $(<0.80) /$ low $\mathrm{CI}(<1.02)$ and the third class is for relatively high MI $(>0.82)$. A further discussion on the discriminations in the high-QI bodies related to the metamorphic domes is made in Section 4.3.

Figure 6 shows the thematic mapping for eight classes of possible rock types, i.e., high quartz/low silicate with some carbonates, high quartz/low silicate with minor carbonates, high quartz/low feldspar with some mafic minerals, carbonates, sulfates, sulfate- or feldspar-rich, ultramafic and mafic-ultramafic. This map suggests good detection of each rock type with the given criteria on the indices.

The criterion to detect ultramafic rocks adopted in Figure 6 is MI $>0.92$, which has been confirmed as a distinct one [14-17]. Since there are not so many high-MI bodies in the northern half of the study area, the relatively low criterion, MI $>0.905$, is adopted for the mafic-ultramafic rocks to detect more candidates of this target. That is why many pixels are erroneously detected as colored blue in Figure 6, especially in the southern part of the study area.

As shown in the VNIR false color image (Figure 2), a lot of lakes are distributed in this study area. The CI image (Figure 5b) indicates the surface water bodies of the lakes have various values of CI, which perhaps reflects the status (solid or liquid), the temperature, and the composition of the water and so on. Further studies are necessary for clarifying the reason for taking a wide range of $\mathrm{CI}$ for the surface water bodies.

The $\mathrm{CI}$ is very sensitive to atmospheric water, as described in Section 2.4. The bodies with a high concentration of the atmospheric water indicate high $\mathrm{CI}$, similar to the carbonate minerals. We can detect the clouds with the VNIR image (Figure 2). However, the bodies concentrated with water vapor are not detectable with VNIR. Therefore, it is important to compare the multi-temporal images of CI. If the features are stably appearing through the multi-temporal images, they are reflecting the surface materials. Otherwise, the features are caused by the atmospheric water concentrations. In this study, we tried to find as much cloud-free ASTER data as possible. However, there are still several small fractions of clouds in the maps, for example around the points $\left(28.1^{\circ} \mathrm{N}, 85.5^{\circ} \mathrm{E}\right),\left(34.9^{\circ} \mathrm{N}, 85.0^{\circ} \mathrm{E}\right)$ and $\left(37.0^{\circ} \mathrm{N}, 89.75^{\circ} \mathrm{E}\right)$, annotated as "Clouds" in Figure 4. The clouds, as well as a part of the snow, ice and lakes, are detected as high-CI pixels in Figure 6. 


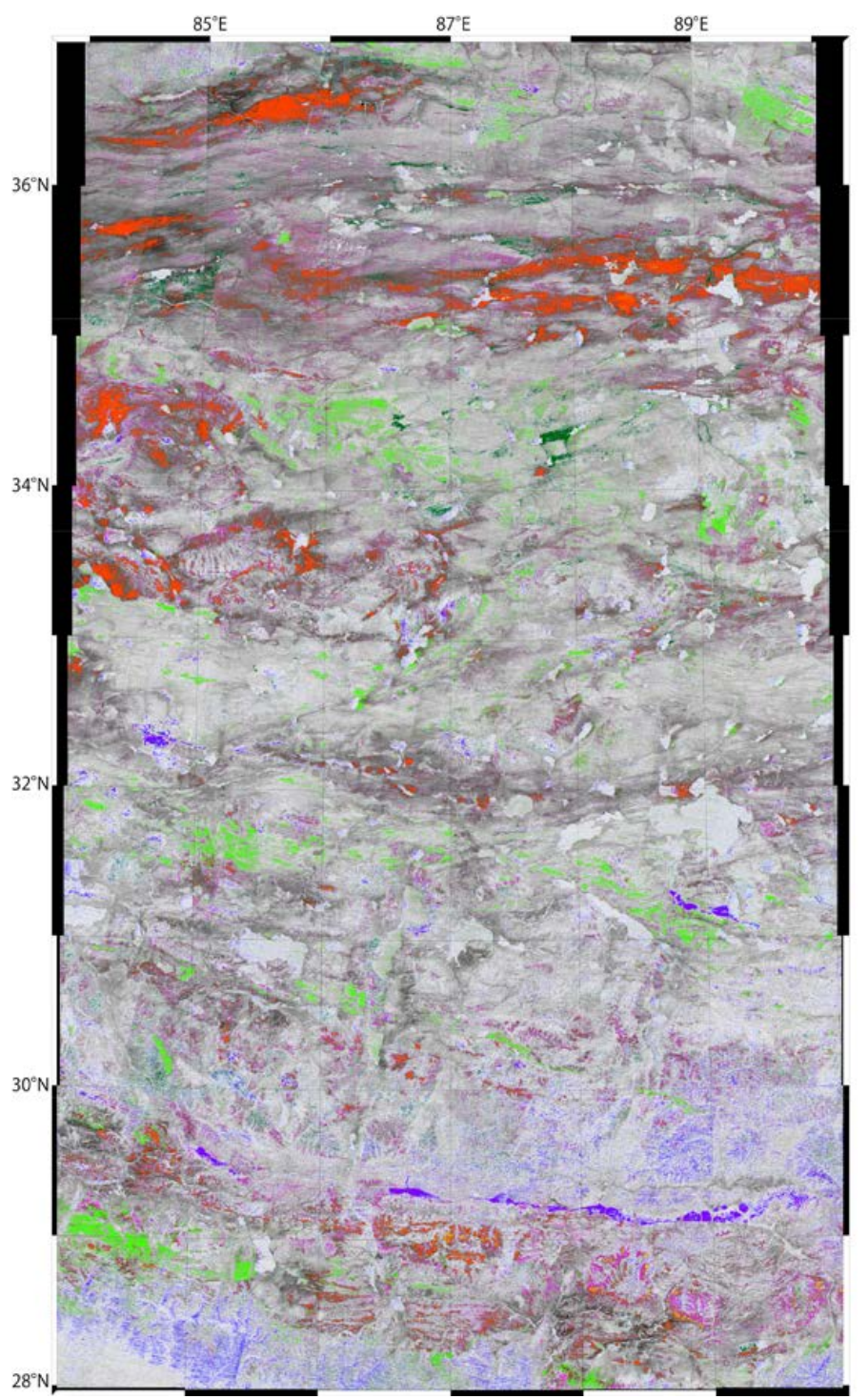

\section{Legends}

2 $\mathrm{Ql}>1.05, \mathrm{MI}<0.8$ and $\mathrm{Cl}>1.02$ (high quartz / low silicates with some carbonate content

Q $\mathrm{Ql}>1.05, \mathrm{Ml}<0.8$ and $\mathrm{Cl}<1.02$ (high quartz / low silicates

$\mathrm{Ql}>1.05$ and $\mathrm{MI}>0.82$ (high quartz / low feldspars with some mafic minerals)

an $\mathrm{Cl}>1.05$ (carbonates)

$\mathrm{Ql}<0.98$

(gypsum)

$0.985>\mathrm{Ql}>0.9$

(gypsum or feldspar rich rock)

- $\mathrm{MI}>0.92$

(ultramafic)

MI $>0.905$

(mafic-ultramafic)

Base image:

$0.9>\mathrm{Ml}>0.75$

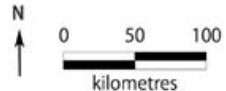

Figure 6. Detected possible rock types colored for each pixel with the given conditions (see legend) on the indices mapped on the grayscale image of MI (0.75-0.9).

There are many snow or ice bodies that do not disappear through the years, as shown in the VNIR image (Figure 2), although other snow bodies usually easily disappear because of the high evaporation rate at the study area which is located in the world's highest-altitude region. These deep snow or ice bodies usually look whitish-green (Figure 4) with relatively high CI. Many glacier bodies are observed in this study area, especially in the Himalaya Mountains, as shown in the VNIR image (Figure 2). It is not possible to get any features in the optical remote sensing data for the materials completely covered with snow or glaciers. However, we can retrieve meaningful signals around the bodies. For example, the lithological features around the peaks of Annapurna II, Manaslu, Ganesh I and Ngadi Chuli in the Himalaya Mountains (annotated as "Pk1", "Pk2", "Pk3" and "Pk4" in Figure 4, respectively) can be drawn from the maps of the indices (Figures 4 and 5). Despite the area around the peaks being covered with snow or ice, as observed in the VNIR image (Figure 2), the indices suggest the major layers around Mt. Annapurna II are carbonate (light-greenish bodies) with minor layers of quartz (reddish bodies). On the other hand, Figure 4 suggests many kinds of layers distributed around the Manaslu Mountains. The peak region appears to be carbonate rocks (light-greenish bodies), and the regions around the glacier valleys in the southwestern part of the peak appear to be feldspar-rich granitic rocks (dark-greenish bodies). The lithological features in the indices around the Ngadi Chuli peak ("Pk4"), 
located south of the Mt. Manaslu, are similar to the ones around the Ganesh I peak ("Pk3"). It suggests the alternation of quartzose and carbonate layers expected in the areas. Further studies are necessary for more solid lithological interpretation with the indices in the Himalaya Mountain region.

The VNIR image (Figure 2) indicates that the southwestern part of the study area in the southern slopes of the Himalaya Mountains in Nepal is heavily covered with vegetation. Most of the signals in the indices are obscured by vegetation; however, we can find some signals in the indices (Figures 4 and 5) along the valleys of the rivers in the area, which are possibly geologically meaningful.

The characteristics of the indices for the geological and other materials in the study area discussed above are summarized in Table 1.

\subsection{Geometrical and Radiometric Performance}

Since the ASTER observes with a pointing angle up to $\pm 8.55^{\circ}$ (for SWIR and TIR subsystems; $\pm 24^{\circ}$ for the VNIR subsystem) in the plane vertical to the moving direction of the satellite [44], the geometrical error caused by the parallax effect in Level-1B and the series of Level-2B data can be one-sixth of the elevation at the target. As the study area covers the world's highest region of the Tibetan Plateau and the Himalaya Mountains, the parallax effect is quite significant. On the other hand, the ortho-rectified Level-3A data are corrected for geometrical errors. Comparing the images covering a part of the study area at just north of the Everest peak (Figure 7), the positional mis-registration in the Level-1B and the Level-2B04 images is indicated as shown below. For sub-area " $\mathrm{A}$ " indicated in Figure 7, the single rock unit shown in the Level-3A image (pointed out with an arrow in Figure 7c) is observed as double (pointed out with two arrows in Figure 7a,b, respectively). Likewise for sub-area " $\mathrm{B}$ ", the lithological boundary between the dark bluish-green unit and the dark pinkish-purple unit shown across the yellow line in Figure 7c is overlapped and a part of the area is missed in Figure 7a,b as indicated with the yellow arrows on the line. These suggest the mis-registration by the parallax effect occurred for Level-1B and Level-2B products, which are corrected for the Level-3A product.

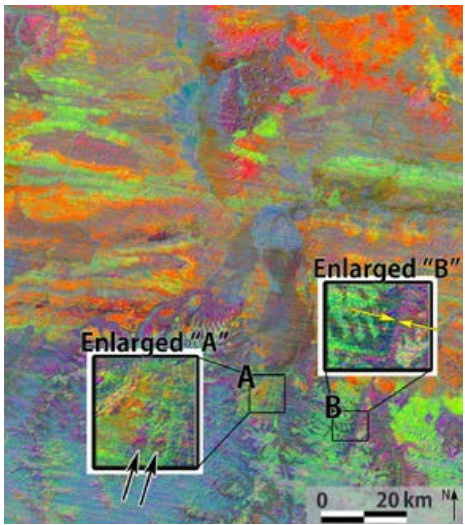

(a)

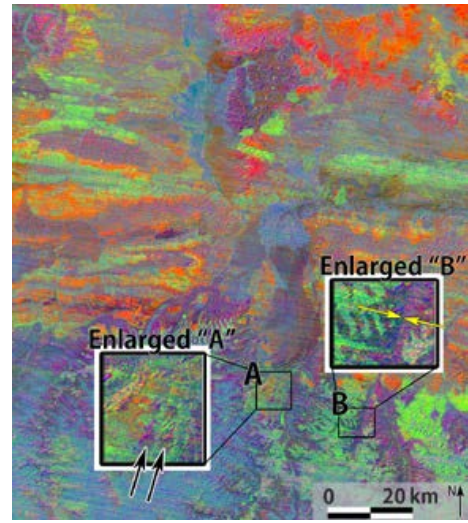

(b)

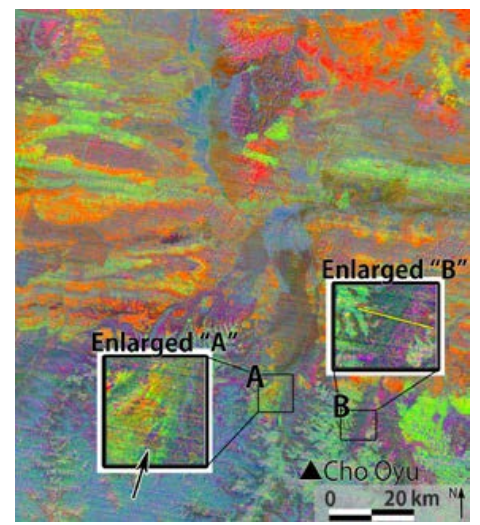

(c)

Figure 7. Mosaic color composite image of QI, $\mathrm{CI}$ and MI covering the region bounded by the latitude $28^{\circ} \mathrm{N}$ to $29^{\circ} \mathrm{N}$ and the longitude $86^{\circ} \mathrm{E}$ to $87^{\circ} \mathrm{E}$ with (a) ASTER Level-1B products; (b) ASTER Level-2B04 products and (c) ASTER LEVEL-3A products. The coverage in the study area is indicated as a yellow rectangle in Figure 2. A linear contrast stretching of 0.97-1.055 (QI; Red), 1.005-1.055 (CI; Green) and 0.79-0.95 (MI; Blue) is applied on (a,c), and 0.975-1.085 (QI; Red), 1.09-1.145 (CI; Green) and 0.76-0.96 (MI; Blue) is applied on (b). The sub-areas " $\mathrm{A}$ " and " $\mathrm{B}$ " are enlarged for pointing out the parallax effects. For "A", the rock unit shown in (c) indicated with an arrow is observed as double in $(a, b)$ as indicated with two arrows. For " $\mathrm{B}$ ", the lithological boundary shown across the yellow line in (c) is overlapped and a part of the area is missed along the boundary in $(a, b)$ as indicated with the yellow arrows on the line. These suggest the geometrical mis-registration by the parallax effect occurred for Level-1B and Level-2B products, which are corrected for the Level-3A product. The location of Mt. Cho Oyu is indicated in (c). 
Table 1. Characteristics of the indices for geological and other materials.

\begin{tabular}{|c|c|c|c|c|c|}
\hline Expected Material & $\begin{array}{l}\text { Typical Geology } \\
\text { in the Study Area }\end{array}$ & $\begin{array}{l}\text { Features in Indices } \\
\text { (Figure 5) }\end{array}$ & $\begin{array}{l}\text { Color in Index Image } \\
\text { (Figure 4) }\end{array}$ & $\begin{array}{l}\text { Detectability with } \\
\text { VNIR (Figure 2) }\end{array}$ & Generality \\
\hline Quartz rich/Feldspars poor & Quartzose sedimentary rocks & QI > 1.05 & Pure to yellowish red & Not clear & Confirmed $[14-19,21-23,26,29,30]$ \\
\hline $\begin{array}{l}\text { Quartz rich/Silicates poor } \\
\text { with some carbonates }\end{array}$ & $\begin{array}{l}\text { Quartzose sedimentary layers } \\
\text { related to Tethys }\end{array}$ & $\begin{array}{l}\mathrm{QI}>1.05, \mathrm{MI}<0.8 \\
\text { and } \mathrm{CI}>1.02\end{array}$ & Yellowish red & Not clear & $\begin{array}{l}\text { Not yet (this study is the } \\
\text { first attempt) }\end{array}$ \\
\hline $\begin{array}{l}\text { Quartz rich/Silicates poor } \\
\text { with minor carbonates }\end{array}$ & $\begin{array}{l}\text { Low-grade metamorphic } \\
\text { sediments around intrusions }\end{array}$ & $\begin{array}{l}\mathrm{QI}>1.05, \mathrm{M}<0.8 \\
\text { and } \mathrm{CI}<1.02\end{array}$ & Pure red & Not clear & $\begin{array}{l}\text { Not yet (this study is the } \\
\text { first attempt) }\end{array}$ \\
\hline $\begin{array}{l}\text { Quartz rich/Feldspars poor } \\
\text { with some mafic minerals }\end{array}$ & $\begin{array}{l}\text { Higher-grade metamorphic } \\
\text { sediments around intrusions }\end{array}$ & $\begin{array}{l}\mathrm{QI}>1.05 \text { and } \\
\mathrm{MI}>0.82\end{array}$ & Red to purplish red & Not clear & $\begin{array}{l}\text { Not yet (this study is the } \\
\text { first attempt) }\end{array}$ \\
\hline Carbonates & $\begin{array}{l}\text { Marine sedimentary layers } \\
\text { related to Tethys }\end{array}$ & $\mathrm{CI}>1.05$ & light green & Not clear & Confirmed [14-19,21,24,25] \\
\hline Sulfates & $\begin{array}{l}\text { Evaporates related to } \\
\text { neo-Tethys }\end{array}$ & QI $<0.98$ & Deep green & Not clear & Confirmed $[15-17,30]$ \\
\hline Ultramafic & Ophiolites related to sutures & $\mathrm{MI}>0.92$ & Light purple & Not clear & Confirmed [14-18,25-30] \\
\hline Feldspar-rich granitic rocks & $\begin{array}{l}\text { Granitic rocks } \\
\text { related to island arc } \\
\text { (e.g., Gandise batholith) }\end{array}$ & $\begin{array}{l}\text { Relatively low } \\
\text { QI/Image pattern }\end{array}$ & Dark bluish green & Not clear & Partially confirmed $[15,17,19,30]$ \\
\hline Feldspar-poor granitic rocks & $\begin{array}{l}\text { Granitic rocks related to } \\
\text { metamorphic domes }\end{array}$ & Image pattern & Dark pinkish purple & Not clear & $\begin{array}{l}\text { Not yet (this study } \\
\text { partially attempts) }\end{array}$ \\
\hline Mafic rocks & Basalt and gabbro & $\begin{array}{l}\text { Relatively high } \\
\text { MI }(\approx 0.90)\end{array}$ & Deep blue & Not clear & Partially confirmed $[15,17]$ \\
\hline Atmospheric water & - & High CI & Light green & Partially (for clouds) & - \\
\hline Snow and ice & - & $\begin{array}{l}\text { Relatively high for } \\
\text { all the indices }\end{array}$ & Whitish green & Yes & - \\
\hline Vegetation & - & $\begin{array}{l}\text { Relatively high } \\
\text { MI }(\approx 0.89)\end{array}$ & Greenish blue & Yes & - \\
\hline Lake water & - & $\begin{array}{l}\text { Relatively high } \\
\text { MI }(\approx 0.89) \text {, Various } \\
\text { values in CI }\end{array}$ & $\begin{array}{l}\text { Various blue to light } \\
\text { green colors }\end{array}$ & Yes & - \\
\hline
\end{tabular}


The mosaic index image of Level-1B data (Figure 7a) and the one of Level-2B04 (Figure 7b) are almost identical in their details, which suggests the radiometric performance of the mosaic index map with the radiance registered at the sensor data (i.e., Level-1B or Level-3A) is not inferior to the one with emissivity (i.e., Level-2B04). The boundary of the scenes composing the mosaic map is not significant in any case of Figure 7a,b,c.

Considering the geometrical and radiometric performances on the ASTER data and the indices discussed above, using the ortho-rectified radiance registered at the sensor data (e.g., Level-3A) is obviously advantageous in the mosaic lithological mapping of this study.

\subsection{Geological Interpretation of the Results}

The characteristics found in the indices (i.e., QI, CI and MI) are discussed in detail in Section 4.1, and summarized in Table 1. Also, a thematic map related to the target rock types is produced with based on the discussion, as shown in Figure 6. In this section, we show more detailed mapping for the high-MI mafic-ultramafic rock bodies and the high-MI lacustrine deposits within the entire study area, and the metamorphic domes [21,36,37] located in the north Himalayan metamorphic belt [38]. These detailed analyses are made by considering the result maps (i.e., Figures 2 and 4, Figures 5 and 6 ) and the discussion in Section 4.1, as shown in Figure 8. A part of these mapping results of the target rocks is compared with the field investigations published so far.

The clearly detectable high-MI ultramafic rocks related to the Indus-Tsangbo Suture (ITS; along line "V" in Figure 4), and the ones of the Yongzhu-Guomangco section and the Dong Tso section related to the Bangong-Nujiang Suture (BNS; along lines "W" and " $\mathrm{X}$ ", respectively, in Figure 4), are mapped according to the criterion of MI $>0.92$ accomplished in Figure 6. The other high-MI bodies are recognized with the criterion $\mathrm{MI}>0.905$. Considering the spatial extent of the detected bodies being checked with the result maps, especially Figures 4 and $5 c$, it is determined whether it is target or not. Considering the VNIR image (Figure 2), the detected high-MI bodies are discriminated between mafic-ultramafic rocks and lacustrine deposits, as shown in Figure 8. To assist readers in locating details of the regional maps, the un-annotated, higher-resolution version of Figures 6 and 8 are presented in the Figures A6 and A7. For the interactive display with the geographical information and DEM that will achieve further convenience to the readers, the color composite image of the indices (Figure 7c) without embedded text and images is converted to a Google Earth compatible KMZ file as presented in the Supplementary Figure S2.

The distribution map of the ultramafic rocks given in this study using the ASTER-TIR data (Figure 8) agrees well with the published maps [39-41,44]. Ninomiya et al. [15,17] suggested the high correlation of the detected ultramafic rocks using ASTER-TIR data with the ones described in the published ophiolite map along the middle Yarlung Zangbo river [44] for the local area south of Xigaze (indicated in Figure 8), but this study suggests the agreement within the entire region of the map. Likewise, the good agreement in the mapping results for the ultramafic rocks of the Yongzhu-Guomangco section [39,40], the Dong Tso section [41] and the Lagkor Tso section [41,42] is suggested.

The advantage of mapping with remote sensing over mapping with a field survey is the heterogenetic observability at the constant interval regardless of the accessibility. On the other hand, whereas the field survey is limited to the area along the accessible routes, it observes many kinds of matters, for example slants and dips of the stratigraphy to reconstruct geology in three dimensions, fossils and radioactive isotope contents in hand samples to determine age, and so on; this is not possible to measure with remote sensing. In that sense, the lithological mapping with remote sensing complements the field geological survey for the materials detectable with the remote sensors in the condition where the rocks appear at the surface over vegetation, snow, and glaciers and so on. Concerning this case study with ASTER-TIR, it can support improving the geological mapping of the materials listed in Table 1, especially of quartz-rich/feldspar-poor rocks, carbonate rocks, ultramafic rocks and sulphatic rocks, which are confirmed to be detected distinctly with the indices as described in Section 4.1 and Table 1. 
Figure 9 shows the comparison of the mapped ultramafic-mafic rocks of this study (Figure 9a) with the published geological map at a scale of 1:250,000 [40] (Figure 9b). The ASTER image shows the ultramafic-mafic rocks distributed along the NW-striking fault zones and provides a more detailed spatial distribution compared with the conventional geological mapping. Additionally, after the specific features for the granitic rocks discussed in Section 4.1 and summarized in Table 1, the granitic intrusive bodies in the east of Guomangco Lake are mapped in Figure 9a, which denotes a dark greenish-blue color with a unique texture and shape in the color index image (Figure 4). The color index image (the background image of Figure 9a cut and enlarged from Figure 4) also indicates the distribution of quartzose and carbonate sediments, which appear yellowish-red and light green, respectively. These mapping results suggest that ASTER-TIR index images (Figures 4 and 5) can provide an efficient approach to map the rock types in the remote and inaccessible Tibetan Plateau with an average elevation of over $4500 \mathrm{~m}$.

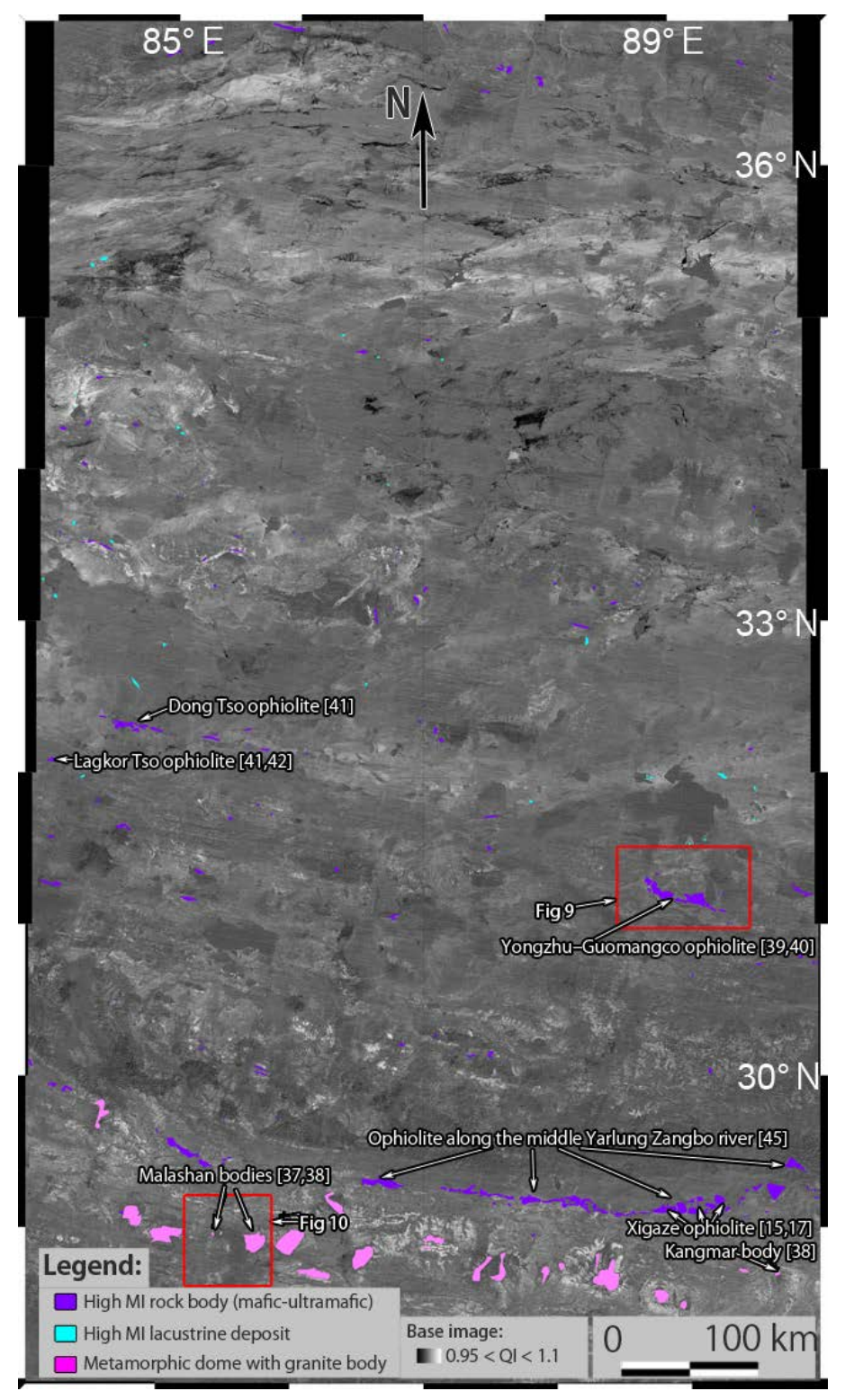

Figure 8. Distribution map for high-MI mafic-ultramafic rock bodies, high-MI lacustrine deposits and metamorphic domes cored with granite, interpreted with the mosaic images of the indices (Figures 4 and 5), VNIR (Figure 2) and the thematic map with the indices (Figure 6) superimposed on the grayscale image of QI. The red rectangles represent the coverage of Figures 9 and 10, respectively. The information of the previous articles with local geological investigations is embedded as the arrowed lines and texts. 

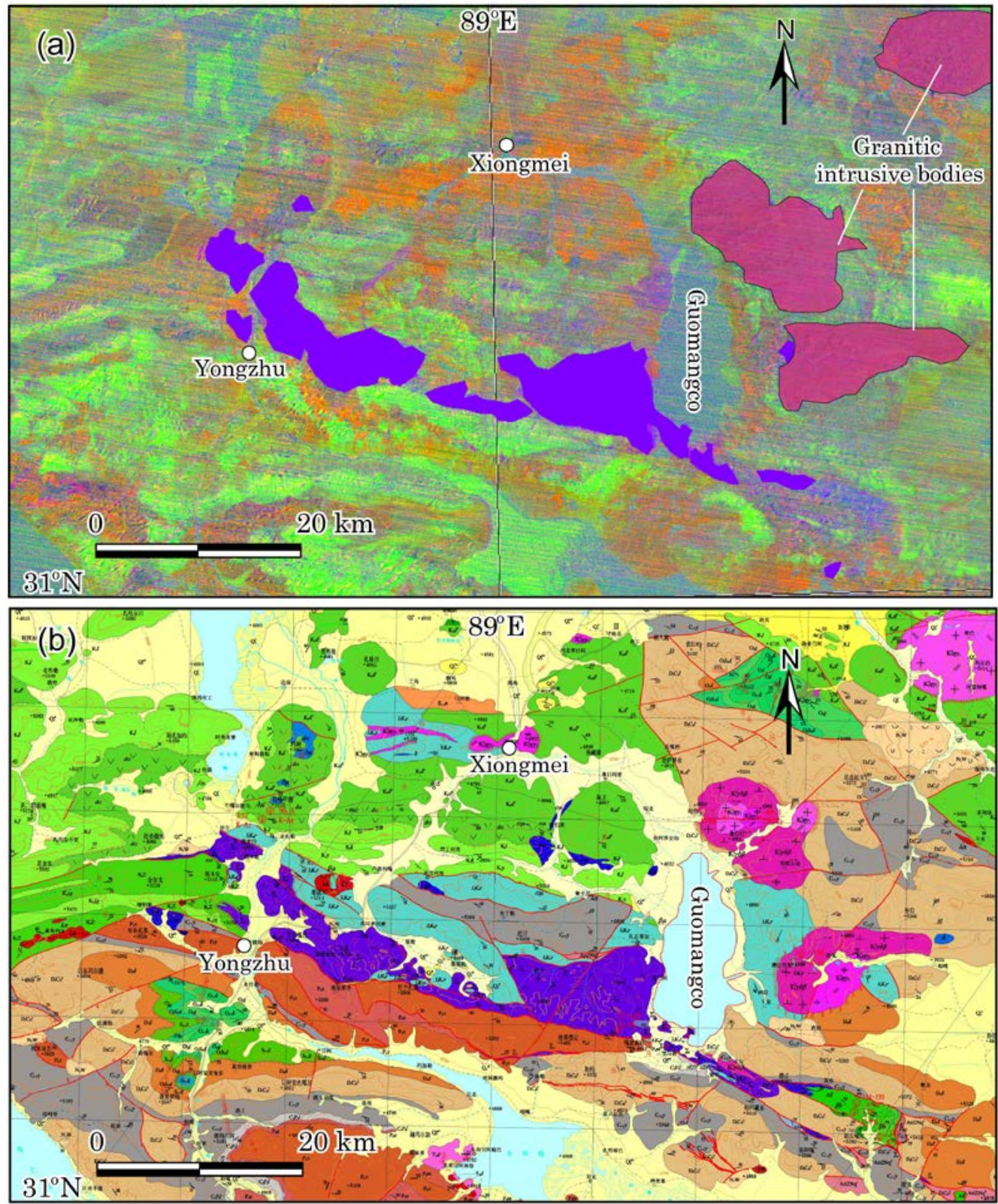

Figure 9. Comparison of (a) the Yongzhu-Guomangco ophiolite map (the polygons colored purple; enlarged from Figure 8) and the map of the granitic intrusive bodies (the polygons colored reddish purple) derived in this study using ASTER TIR data superimposed on the color composite image of the indices (Figure 4) with (b) the published geological map based on the field investigations (e.g., [39,40]). The coverage of this figure is shown as the red rectangle in Figure 8.

Figure 8 also maps the rock bodies related to the north Himalayan metamorphic domes [21,36-38] intruded during the Cenozoic Era to the accretionany wedges of the south Tibetan detachment system, located in the E-W direction in the Himalaya terrane at the southern part of the Indus-Tsangbo Suture. According to the compiled map by Burrell et al. [36] with the published 1:1,500,000 scale geological map [44], granite and granitic gneiss at the core of the domes are accompanied with high-grade metamorphosed gneissose sediments around the core and low-grade metamorphosed sediments around the gneiss in the eastern half of the region (in longitude $87^{\circ} \mathrm{E}$ and further eastern). On the other hand, it is not so well accompanied by those high-grade and low-grade metamorphosed rocks in the western half of the region (in longitude $87^{\circ} \mathrm{E}$ and further western). 
As discussed in Section 4.1, the characteristics of the indices for the types of granitic rocks are not so distinct at the individual pixels; however, it can be mapped considered together with the unique shape and paternal textures recognized in the images of the indices (Figures 4 and 5). As summarized in Table 1, granitic rocks with relatively high feldspar content appear as dark bluish-green color in the index image (Figure 4). On the other hand, the dominant granitic rocks distributed related to the domes look dark pinkish-purple (Figure 4). This color is probably reflecting less feldspar content. The relatively feldspar-rich granitic rocks of the dark bluish-green color (Figure 4) are also widely distributed in this region related to the domes.

Comparing the colors of the targets (i.e., the rocks associated with the domes) in the image of the indices (Figure 4) with the previous studies [21,36-38] and the geological map [44], we assume that the dark pinkish-purple bodies correspond to the cored and the high-grade metamorphosed granitic rocks. Likewise, we assume the correspondences of the dark bluish-green bodies to the feldspar-rich granitic rocks, the pinkish-red bodies to the high-grade metamorphosed sediments and the pure reddish bodies to the low-grade metamorphosed sediments, respectively. The mapped granitic bodies in Figure 8 are only for the ones with a dark pinkish-purple color, because they are the most prominent target characterizing the metamorphic domes. The similar types of bodies in the Himalaya Mountains and the Gandise Mountains are omitted from the mapping (Figure 8). However, the body at the southern part of Mt. Loinbo Kangri (indicated in Figure 2), which was not mapped previously [36-38,45] for being recognized as a part of the Gandise granitic rock group, is included in this map (Figure 8) because it is located just south of the Gandise Mountains within the Tethyan quartzose and carbonate sediments related to the south Tibetan detachment system, as suggested in Figure 4. As this study is the first case to attempt detecting these kinds of rock types with these indices, the generality of which has not yet been confirmed (Table 1), the mapping result of the metamorphic domes shown in Figure 8 presents a preliminary case.

The Kangmar dome and the western portion of the Malashan dome, the locations of which are indicated in Figure 8, are the best-investigated ones from the previous studies [37,38]. They are dominated by the dark bluish-green (Figure 4) bodies assumed here as the feldspar-rich granitic rocks. On the other hand, most of the other domes are dominated with the dark pinkish-purple bodies which are assumed here as the relatively feldspar-poor granites and high-grade metamorphosed ones. As the target of the mapping in this study (Figure 8) is the latter, very small bodies are mapped for the Kangmar and the western Malashan units compared to the published maps [36,45].

Several domes are newly mapped in Figure 8 in addition to the known ones mapped so far [36,45], typically the one just west of the Kangmar dome (Figure 8). Further advancements are necessary in the field for the validity of the new mapping.

According to Figures 4 and 6, most of the domes are accompanied by the Tethyan quartzose sediments of the pinkish-red bodies (Figure 4), assumed here as high-grade metamorphosed sediments, and reddish bodies (Figure 4), assumed here as low-grade metamorphosed sediments. Figure 4 suggests that the association is more obvious for the domes in the eastern half of the region compared to the ones in the western half, as indicated by Burrell et al. [36]. Probably, the reason for the difference is because the domes in the eastern half of the region are intruded into the accretionary wedges dominated with quartzose sediments; on the other hand, the ones in the western half are intruded into the ones dominated with carbonate sediments as inferred from the index map (Figure 4).

Figure 10 shows the comparison of the lithological mapping using the color index image (Figure 4) with the geological summary map investigated by Aoya et al. [37] around the western Malashan dome located in the western shore region of Paiku Lake. This figure indicates good agreement between our result and Aoya's result. The spatial extents for some of the geological bodies are more closely mapped in this study, as expected with the strong points of remote sensing described earlier in this section. On the other hand, it is difficult to distinguish between two-mica granites and leucogranites with the approach of this study, which is inferred as the difference of the chemical or mineral composition in the two types of granite is not as significantly detectable with ASTER-TIR. Some high-QI bodies 
detected as quartzose sediments in the map of this study (Figure 10a), for example the one just west of the Paiku leucogranite body, are classified as calc schist in Aoya's map (Figure 10b). The units mapped as pelitic schist in Aoya's map correspond well to the high-QI/relatively low-CI bodies with a pure reddish color in the map of this study (Figure 10a), assumed here as low-grade metamorphosed quartzose sediments.

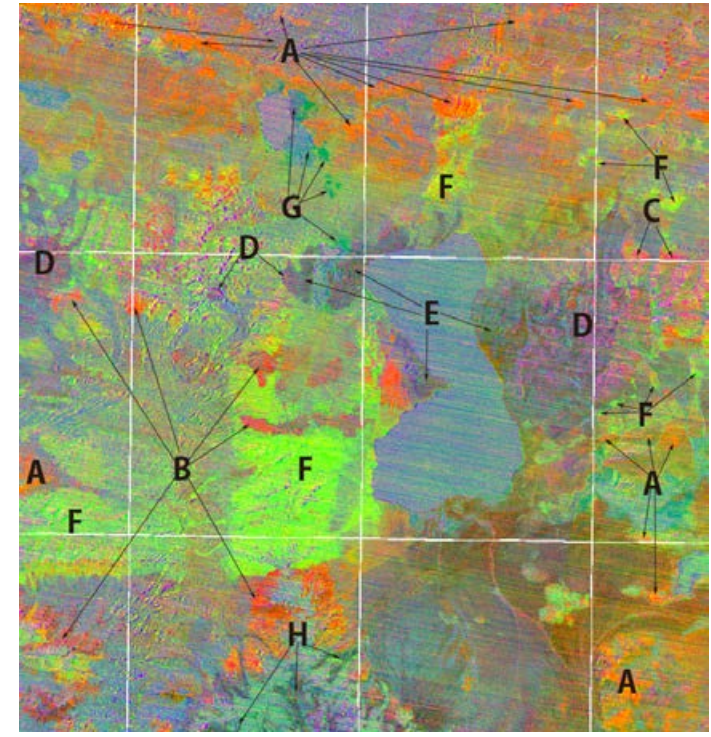

(a)

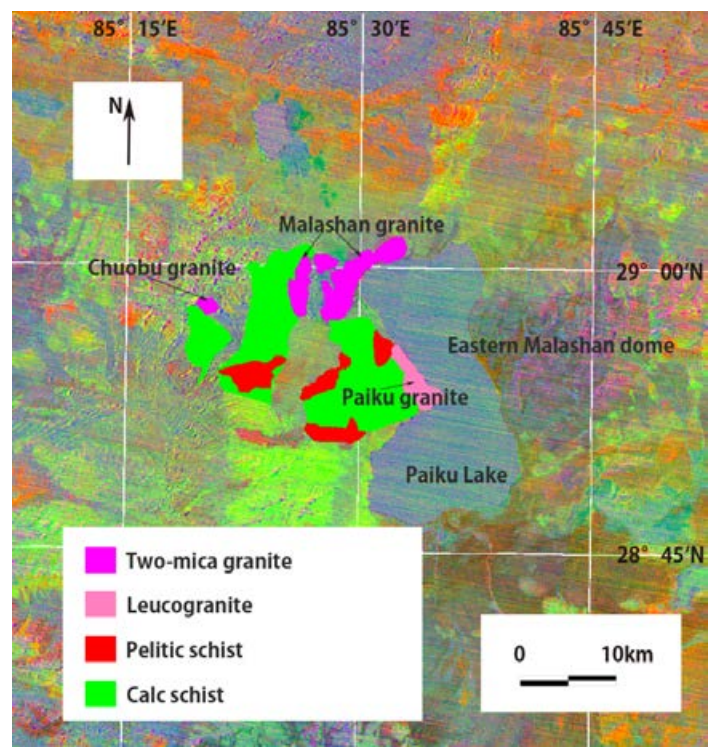

(b)

Figure 10. (a) Lithological mapping with the mosaic color composite image of QI, CI and MI around the Malashan domes. The coverage of this image is indicated in Figure 8. The interpreted rock types with this image are A: Quartzose sedimentary layers related to the Tethys, colored yellowish-red; B: Low-grade metamorphic quartzose Tethyan sediments related to the intrusion, colored pure red; C: High-grade metamorphic quartzose Tethyan sediments around metamorphic domes, colored pinkish-red; D: Relatively feldspar-poor granitic rocks related to the domes, colored dark pinkish-purple; E: Feldspar-rich granitic rocks around the domes, colored dark bluish-green; F: Carbonate layers related to the Tethys, colored light green; G: Sulfate deposits, colored deep green; H: Feldspar-rich granitic rocks at the glacier valleys in the north slope of the Himalaya Mountains; (b) Geological map around the western Malashan metamorphic dome area investigated by Aoya et al. [37] embedded in the color composite image of the indices.

Apart from the geological units mapped by Aoya et al. [37], there are many lithological features that are mappable with the color index image (Figure 10a) where alphabetic symbols are annotated in the figure to indicate the targets. As described in Section 4.1 and summarized in Table 1, quartz-rich/feldspar-poor layers, carbonate layers and sulfate deposits are distinctively detected as " $\mathrm{A}$ " to " $\mathrm{C}$ ", " $\mathrm{F}$ " and " $\mathrm{G}$ ", respectively, according to the colors based on the features in the indices. Feldspar-rich granitic rocks detected at " $\mathrm{E}$ " and " $\mathrm{H}$ " are discriminated with another type of granitic rock detected around " $\mathrm{D}$ ", which are mapped as the metamorphic dome in Figure 8, as the color for the former is dark bluish-green whereas that for the latter is dark pinkish-purple. This is the first study of the latter granitic rocks with reference to the indices for ASTER-TIR data. Also, this study attempts classifying the high-QI layers into three classes, i.e., relatively high-CI/low-MI layers assumed here as non-metamorphosed quartzose sediments, relatively low-CI/low-MI layers assumed here as low-grade metamorphic quartzose sediments, and relatively high-MI layers assumed here as high-grade metamorphic quartzose sediments. In Figure 10a, these rock types are distributed at " $\mathrm{A}$ ", " $\mathrm{B}$ " and " $\mathrm{C}$ ", respectively. The materials detected with the features in the indices given in this study for the first time are determined under assumptions, which should be confirmed with the field investigations. 
As a summary, although much of the information needed for geological mapping is acquired only with the field investigations, the complementary use of this approach will improve the quality of mapping in detecting the exact spatial extent of the target materials of this study.

\section{Conclusions}

ASTER TIR mineralogical indices, i.e., QI, CI, and MI, were defined on the basis of the spectral properties of typical geological materials and applied to a large central region of the Tibetan Plateau. The advantages of using the ortho-rectified radiance registered at the sensor data (e.g., Level-3A products) were discussed in addition to sensor geometrical and radiometric performances. The maps were interpreted to accomplish more detailed mapping of ultramafic rock bodies and north Himalayan metamorphic granite bodies. This study sought to differentiate granitic rock types according to the abundance of feldspars, as well as the classification of the quartzose sedimentary layers according to the content of carbonates and mafic minerals. Results indicate that lithological mapping using TIR spectral indices was successful in detecting quartzose sedimentary, carbonate, and sulphatic layers, in addition to ultramafic bodies, which had been confirmed from previous remote sensing investigations. The results from the detailed mapping were compared to prior field-based geological mapping studies and it was found that they also agreed well. The advantage of using remote sensing to detect the spatial extent of the target materials, i.e., its superiority over conventional geological mapping, has been well established. However, the geological materials detected using these described techniques need to be confirmed through a vigorous campaign of ground-based field investigations. A further survey is planned where regional lithological mapping will be applied to the entire Tibetan Plateau, as well as to areas in northwestern China, such as the Tarim Basin and the surrounding area.

Supplementary Materials: The following are available online at www.mdpi.com/2076-3263/6/3/39. Figure S1. Mosaic color composite image of QI, CI and MI with a linear contrast stretch of 0.97-1.055 (QI; Red), 1.005-1.055 (CI; Green) and 0.79-0.95 (MI; Blue), produced with ASTER Level-3A products covering the entire study area. The pixel is re-sampled every $9 \mathrm{~s}$, and the image is compressed with jpeg format. This KMZ file is converted from Figure 4 without annotations. Figure S2. Mosaic color composite image of QI, CI and MI with a linear contrast stretch of 0.97-1.055 (QI; Red), 1.005-1.055 (CI; Green) and 0.79-0.95 (MI; Blue), produced with ASTER Level-3A products covering the north western part of Mt. Everest bounded by latitude $28^{\circ} \mathrm{N}$ to $29^{\circ} \mathrm{N}$ and longitude $86^{\circ} \mathrm{E}$ to $87^{\circ} \mathrm{E}$. The pixel is re-sampled every $3 \mathrm{~s}$, and the image is not compressed. This $\mathrm{KMZ}$ file is converted from Figure 7c.

Acknowledgments: The ASTER data used in this study are supplied by Japan Space Systems. ASTER data are credited to NASA/METI/AIST/Japan Space Systems, and U.S./Japan ASTER Science Team. Comments of Robert Corrie, The Queen's College, University of Oxford and Koki Iwao, AIST, as well as of the four anonymous reviewers and the academic editors, have substantially improved the manuscript. This work was supported by the Strategic Priority Research Program of the Chinese Academy of Sciences (Grant No. XDB03020200).

Author Contributions: Yoshiki Ninomiya performed the ASTER data processing. Bihong Fu prepared the description of the geological setting of the study area. Yoshiki Ninomiya and Bihong Fu collaboratively discussed the results. Bihong Fu prepared Figure 1, Bihong Fu and Yoshiki Ninomiya cooperatively prepared Figure 9, and Yoshiki Ninomiya prepared the other figures.

Conflicts of Interest: The authors declare no conflict of interest.

\section{Abbreviations}

The following abbreviations are used in this manuscript:

ASTER Advanced Spaceborne Thermal Emission and Reflection Radiometer

VNIR Visible and Near Infrared

TIR Thermal Infrared

QI Quartz Index

CI Carbonate Index

MI Mafic Index

JSS Japan Space Systems 


\section{Appendix}

Table A1. The list of the ASTER products composing the produced regional maps (Figures 4 and 5).

\begin{tabular}{|c|c|c|c|c|c|}
\hline $\begin{array}{l}\mathbf{1}^{\circ} \times \mathbf{1}^{\circ} \text { Tile's } \\
\text { South-Western Corner } \\
\text { (Latitude, Longitude) }\end{array}$ & $\begin{array}{l}\text { JSS Granule ID }{ }^{1,2} \text { of ASTER Product Used for } \\
\text { Mapping, Listed in the Order of Priority }\end{array}$ & $\begin{array}{l}\text { Observation Date } \\
\text { (yyyymmdd) }\end{array}$ & $\begin{array}{l}\text { Latitude at the } \\
\text { Scene Center }\left({ }^{\circ} \mathrm{N}\right)\end{array}$ & $\begin{array}{l}\text { Longitude at the } \\
\text { Scene Center }\left({ }^{\circ} \mathrm{E}\right)\end{array}$ & $\begin{array}{l}\text { Number of Products } \\
\text { (Number Redundant) } \\
\text { for Level-3A, Level-1B }\end{array}$ \\
\hline \multirow{10}{*}{$\left(37^{\circ} \mathrm{N}, 84^{\circ} \mathrm{E}\right)$} & AST3A1 0309030508571206150053 & 20030903 & 35.9 & 84.91 & \multirow{10}{*}{$10(0), 0(0)$} \\
\hline & AST3A1 0111160513301206150006 & 20011116 & 36.98 & 85.07 & \\
\hline & AST3A1 0111160513391206150010 & 20011116 & 36.45 & 84.92 & \\
\hline & AST3A1 0111160513471206150055 & 20011116 & 35.91 & 84.78 & \\
\hline & AST3A1 0711150521311206150007 & 20071115 & 36.09 & 84.26 & \\
\hline & AST3A1 0611210514581206150011 & 20061121 & 36.8 & 84.75 & \\
\hline & AST3A1 0711150521221206150012 & 20071115 & 36.62 & 84.42 & \\
\hline & AST3A1 0803060521291206150015 & 20080306 & 37.21 & 84.19 & \\
\hline & AST3A1 0803060521381206150017 & 20080306 & 36.68 & 84.03 & \\
\hline & AST3A1 0802030521581206150021 & 20080203 & 36.10 & 84.20 & \\
\hline \multirow{12}{*}{$\left(37^{\circ} \mathrm{N}, 85^{\circ} \mathrm{E}\right)$} & AST3A1 0310280515391206150051 & 20031028 & 36.16 & 85.38 & \multirow{12}{*}{$12(1), 0(0)$} \\
\hline & AST3A1 0609180514551507170001 & 20060918 & 37.15 & 86.11 & \\
\hline & AST3A1 0107020523241507170001 & 20010702 & 37.22 & 85.68 & \\
\hline & AST3A1 0309030508481206150009 & 20030903 & 36.42 & 85.05 & \\
\hline & *AST3A1 0309030508571206150053 & 20030903 & 35.9 & 84.91 & \\
\hline & AST3A1 0310280515301507170001 & 20031028 & 36.69 & 85.54 & \\
\hline & AST3A1 0309030508391507170001 & 20030903 & 36.96 & 85.2 & \\
\hline & AST3A1 0308020508371507170001 & 20030802 & 36.26 & 86.21 & \\
\hline & AST3A1 0308020508461507170001 & 20030802 & 35.73 & 86.05 & \\
\hline & AST3A1 0011290522221507170001 & 20001129 & 36.28 & 86.13 & \\
\hline & AST3A1 0209230516581507170001 & 20020923 & 36.64 & 85.84 & \\
\hline & AST3A1 0011040529001503130001 & 20001104 & 36.10 & 85.74 & \\
\hline \multirow{9}{*}{$\left(37^{\circ} \mathrm{N}, 86^{\circ} \mathrm{E}\right)$} & AST3A1 0107110517171507170001 & 20010711 & 37.23 & 87.14 & \multirow{9}{*}{$9(3), 0(0)$} \\
\hline & AST3A1 0107110517261507170001 & 20010711 & 36.70 & 86.98 & \\
\hline & AST3A1 0107110517351507140001 & 20010711 & 36.17 & 86.82 & \\
\hline & AST3A1 0209160510511507170001 & 20020916 & 36.76 & 86.59 & \\
\hline & *AST3A1 0609180514551507170001 & 20060918 & 37.15 & 86.11 & \\
\hline & AST3A1 0308020508281507170001 & 20030802 & 36.79 & 86.36 & \\
\hline & *AST3A1 0308020508371507170001 & 20030802 & 36.26 & 86.21 & \\
\hline & *AST3A1 0308020508461507170001 & 20030802 & 35.73 & 86.05 & \\
\hline & AST3A1 0011290522131507170001 & 20001129 & 36.81 & 86.28 & \\
\hline
\end{tabular}


Table A1. Cont.

\begin{tabular}{|c|c|c|c|c|c|}
\hline $\begin{array}{l}\quad \mathbf{1}^{\circ} \times \mathbf{1}^{\circ} \text { Tile's }^{\prime} \\
\text { South-Western Corner } \\
\text { (Latitude, Longitude) }\end{array}$ & $\begin{array}{l}\text { JSS Granule ID }{ }^{1,2} \text { of ASTER Product Used for } \\
\text { Mapping, Listed in the Order of Priority }\end{array}$ & $\begin{array}{l}\text { Observation Date } \\
\text { (yyyymmdd) }\end{array}$ & $\begin{array}{l}\text { Latitude at the } \\
\text { Scene Center }\left({ }^{\circ} \mathrm{N}\right)\end{array}$ & $\begin{array}{l}\text { Longitude at the } \\
\text { Scene Center }\left({ }^{\circ} \mathrm{E}\right)\end{array}$ & $\begin{array}{l}\text { Number of Products } \\
\text { (Number Redundant) } \\
\text { for Level-3A, Level-1B }\end{array}$ \\
\hline \multirow{13}{*}{$\left(37^{\circ} \mathrm{N}, 87^{\circ} \mathrm{E}\right)$} & *AST3A1 0107110517351507140001 & 20010711 & 36.17 & 86.82 & \multirow{13}{*}{$13(3), 0(0)$} \\
\hline & *AST3A1 0107110517261507170001 & 20010711 & 36.70 & 86.98 & \\
\hline & *AST3A1 0107110517171507170001 & 20010711 & 37.23 & 87.14 & \\
\hline & AST3A1 0307190456141507160001 & 20030719 & 36.96 & 88.26 & \\
\hline & AST3A1 0307190456231507160001 & 20030719 & 36.43 & 88.11 & \\
\hline & AST3A1 0307190456311507140001 & 20030719 & 35.90 & 87.97 & \\
\hline & AST3A1 0110240508261507170001 & 20011024 & 36.82 & 87.70 & \\
\hline & AST3A1 0110240508431507140001 & 20011024 & 35.76 & 87.39 & \\
\hline & AST3A1 0010280522441507170001 & 20001028 & 37.16 & 87.59 & \\
\hline & AST3A1 0010280522531507170001 & 20001028 & 36.63 & 87.42 & \\
\hline & AST3A1 0010280523021507140001 & 20001028 & 36.11 & 87.26 & \\
\hline & AST3A1 0510280456161507160001 & 20051028 & 36.45 & 87.97 & \\
\hline & AST3A1 0510280456251507140001 & 20051028 & 35.92 & 87.82 & \\
\hline \multirow{9}{*}{$\left(37^{\circ} \mathrm{N}, 88^{\circ} \mathrm{E}\right)$} & AST3A1 0204110458101507160001 & 20020411 & 36.86 & 89.03 & \multirow{9}{*}{$9(3), 0(0)$} \\
\hline & AST3A1 0204110458191507160001 & 20020411 & 36.33 & 88.88 & \\
\hline & AST3A1 0204110458281507140001 & 20020411 & 35.80 & 88.73 & \\
\hline & AST3A1 0403310457161507140001 & 20040331 & 35.85 & 88.34 & \\
\hline & *AST3A1 0307190456141507160001 & 20030719 & 36.96 & 88.26 & \\
\hline & *AST3A1 0307190456231507160001 & 20030719 & 36.43 & 88.11 & \\
\hline & *AST3A1 0307190456311507140001 & 20030719 & 35.90 & 87.97 & \\
\hline & AST3A1 0709160457131507160001 & 20070916 & 36.93 & 88.49 & \\
\hline & AST3A1 0709160457221507160001 & 20070916 & 36.40 & 88.34 & \\
\hline \multirow{9}{*}{$\left(37^{\circ} \mathrm{N}, 89^{\circ} \mathrm{E}\right)$} & AST3A1 0009120512131507160001 & 20000912 & 35.78 & 88.85 & \multirow{9}{*}{$9(0), 0(0)$} \\
\hline & AST3A1 0009120512041507160001 & 20000912 & 36.31 & 89.00 & \\
\hline & AST3A1 0009120511551507160001 & 20000912 & 36.84 & 89.16 & \\
\hline & AST3A1 0610080450061507160001 & 20061008 & 36.91 & 90.21 & \\
\hline & AST3A1 0309210456331507160001 & 20030921 & 36.68 & 90.22 & \\
\hline & AST3A1 0309210456421507140001 & 20030921 & 36.15 & 90.06 & \\
\hline & AST3A1 0110100456491507140001 & 20011010 & 35.93 & 89.32 & \\
\hline & AST3A1 0712210457011507160001 & 20071221 & 36.75 & 89.76 & \\
\hline & AST3A1 0712210457101507160001 & 20071221 & 36.22 & 89.60 & \\
\hline
\end{tabular}


Table A1. Cont.

\begin{tabular}{|c|c|c|c|c|c|}
\hline $\begin{array}{l}\quad 1^{\circ} \times 1^{\circ} \text { Tile's } \\
\text { South-Western Corner } \\
\text { (Latitude, Longitude) }\end{array}$ & $\begin{array}{l}\text { JSS Granule ID }{ }^{1,2} \text { of ASTER Product Used for } \\
\text { Mapping, Listed in the Order of Priority }\end{array}$ & $\begin{array}{l}\text { Observation Date } \\
\text { (yyyymmdd) }\end{array}$ & $\begin{array}{l}\text { Latitude at the } \\
\text { Scene Center }\left({ }^{\circ} \mathrm{N}\right)\end{array}$ & $\begin{array}{l}\text { Longitude at the } \\
\text { Scene Center }\left({ }^{\circ} \mathrm{E}\right)\end{array}$ & $\begin{array}{l}\text { Number of Products } \\
\text { (Number Redundant) } \\
\text { for Level-3A, Level-1B }\end{array}$ \\
\hline \multirow{14}{*}{$\left(36^{\circ} \mathrm{N}, 84^{\circ} \mathrm{E}\right)$} & *AST3A1 0309030508571206150053 & 20030903 & 35.90 & 84.91 & \multirow{14}{*}{$12(3), 0(0)$} \\
\hline & AST3A1 0309030509061206150056 & 20030903 & 35.37 & 84.76 & \\
\hline & AST3A1 0309030509141206130024 & 20030903 & 34.83 & 84.62 & \\
\hline & *AST3A1 0111160513471206150055 & 20011116 & 35.91 & 84.78 & \\
\hline & AST3A1 0111160513561206150054 & 20011116 & 35.38 & 84.64 & \\
\hline & AST3A1 0111160514051206130022 & 20011116 & 34.85 & 84.49 & \\
\hline & AST3A1 0103280526261206150008 & 20010328 & 35.75 & 84.39 & \\
\hline & AST3A1 0103280526351507160001 & 20010328 & 35.22 & 84.24 & \\
\hline & *AST3A1 0711150521311206150007 & 20071115 & 36.09 & 84.26 & \\
\hline & AST3A1 0711150521401206150005 & 20071115 & 35.56 & 84.09 & \\
\hline & AST3A1 0711150521481507160001 & 20071115 & 35.03 & 83.93 & \\
\hline & AST3A1 0310280515571507150001 & 20031028 & 35.10 & 85.07 & \\
\hline & AST3A1 0704140516131206130029 & 20070414 & 35.22 & 84.25 & \\
\hline & AST3A1 0802280515581206130033 & 20080228 & 35.27 & 83.93 & \\
\hline \multirow{13}{*}{$\left(36^{\circ} \mathrm{N}, 85^{\circ} \mathrm{E}\right)$} & AST3A1 0209160511091507160001 & 20020916 & 35.70 & 86.27 & \multirow{13}{*}{$13(5), 0(0)$} \\
\hline & *AST3A1 0309030509061206150056 & 20030903 & 35.37 & 84.79 & \\
\hline & *AST3A1 0310280515391206150051 & 20031028 & 36.16 & 85.38 & \\
\hline & AST3A1 0310280515481206150003 & 20031028 & 35.63 & 85.22 & \\
\hline & *AST3A1 0309030508571206150053 & 20030903 & 35.90 & 84.91 & \\
\hline & AST3A1 0210020511091507160001 & 20021002 & 34.69 & 85.65 & \\
\hline & *AST3A1 0011040529001503130001 & 20001104 & 36.10 & 85.74 & \\
\hline & AST3A1 0011040529181507160001 & 20001104 & 35.04 & 85.42 & \\
\hline & AST3A1 0012150522071503130001 & 20001215 & 36.28 & 86.12 & \\
\hline & AST3A1 0012150522161503130001 & 20001215 & 35.75 & 85.96 & \\
\hline & AST3A1 0012150522251503130001 & 20001215 & 35.22 & 85.81 & \\
\hline & *AST3A1 0310280515571507150001 & 20031028 & 35.10 & 85.07 & \\
\hline & AST3A1 0712260515531507300001 & 20071226 & 35.57 & 85.58 & \\
\hline
\end{tabular}


Table A1. Cont.

\begin{tabular}{|c|c|c|c|c|c|}
\hline $\begin{array}{l}\mathbf{1}^{\circ} \times \mathbf{1}^{\circ} \text { Tile's }^{\prime} \\
\text { South-Western Corner } \\
\text { (Latitude, Longitude) }\end{array}$ & $\begin{array}{l}\text { JSS Granule ID }{ }^{1,2} \text { of ASTER Product Used for } \\
\text { Mapping, Listed in the Order of Priority }\end{array}$ & $\begin{array}{l}\text { Observation Date } \\
\text { (yyyymmdd) }\end{array}$ & $\begin{array}{l}\text { Latitude at the } \\
\text { Scene Center }\left({ }^{\circ} \mathrm{N}\right)\end{array}$ & $\begin{array}{l}\text { Longitude at the } \\
\text { Scene Center }\left({ }^{\circ} \mathrm{E}\right)\end{array}$ & $\begin{array}{l}\text { Number of Products } \\
\text { (Number Redundant) } \\
\text { for Level-3A, Level-1B }\end{array}$ \\
\hline \multirow{11}{*}{$\left(36^{\circ} \mathrm{N}, 86^{\circ} \mathrm{E}\right)$} & *AST3A1 0010280523021507140001 & 20001028 & 36.11 & 87.26 & \multirow{11}{*}{$11(5), 0(0)$} \\
\hline & AST3A1 0010280523111507140001 & 20001028 & 35.58 & 87.10 & \\
\hline & AST3A1 0010280523201507140001 & 20001028 & 35.05 & 86.94 & \\
\hline & AST3A1 0107110517441507140001 & 20010711 & 35.64 & 86.66 & \\
\hline & *AST3A1 0209160511091507160001 & 20020916 & 35.70 & 86.27 & \\
\hline & *AST3A1 0308020508371507170001 & 20030802 & 36.26 & 86.21 & \\
\hline & *AST3A1 0012150522161503130001 & 20001215 & 35.75 & 85.96 & \\
\hline & *AST3A1 0012150522251503130001 & 20001215 & 35.22 & 85.81 & \\
\hline & AST3A1 0410230508261507170001 & 20041023 & 36.17 & 86.82 & \\
\hline & AST3A1 0410230508441503130001 & 20041023 & 35.11 & 86.51 & \\
\hline & AST3A1 0703060510091503130001 & 20070306 & 35.17 & 86.15 & \\
\hline \multirow{12}{*}{$\left(36^{\circ} \mathrm{N}, 87^{\circ} \mathrm{E}\right)$} & AST3A1 0110240508341507170001 & 20011024 & 36.29 & 87.55 & \multirow{12}{*}{$12(6), 0(0)$} \\
\hline & *AST3A1 0110240508431507140001 & 20011024 & 35.76 & 87.39 & \\
\hline & AST3A1 0110240508521507140001 & 20011024 & 35.23 & 87.24 & \\
\hline & *AST3A1 0010280523021507140001 & 20001028 & 36.11 & 87.26 & \\
\hline & *AST3A1 0010280523111507140001 & 20001028 & 35.58 & 87.10 & \\
\hline & *AST3A1 0010280523201507140001 & 20001028 & 35.05 & 86.94 & \\
\hline & *AST3A1 0403310457161507140001 & 20040331 & 35.85 & 88.34 & \\
\hline & AST3A1 0709160457391507140001 & 20070916 & 35.34 & 88.04 & \\
\hline & AST3A1 0709160457481504130001 & 20070916 & 34.81 & 87.90 & \\
\hline & *AST3A1 0510280456251507140001 & 20051028 & 35.92 & 87.82 & \\
\hline & AST3A1 0510280456341507140001 & 20051028 & 35.39 & 87.68 & \\
\hline & AST3A1 0510280456431504130001 & 20051028 & 34.86 & 87.53 & \\
\hline \multirow{10}{*}{$\left(36^{\circ} \mathrm{N}, 88^{\circ} \mathrm{E}\right)$} & *AST3A1 0403310457161507140001 & 20040331 & 35.85 & 88.34 & \multirow{10}{*}{$10(4), 0(0)$} \\
\hline & AST3A1 0403310457251507140001 & 20040331 & 35.32 & 88.20 & \\
\hline & AST3A1 0403310457341507140001 & 20040331 & 34.79 & 88.05 & \\
\hline & *AST3A1 0204110458281507140001 & 20020411 & 35.80 & 88.73 & \\
\hline & AST3A1 0204110458361507140001 & 20020411 & 35.26 & 88.58 & \\
\hline & AST3A1 0204110458451507140001 & 20020411 & 34.73 & 88.43 & \\
\hline & *AST3A1 0110100456491507140001 & 20011010 & 35.93 & 89.32 & \\
\hline & AST3A1 0110100456581507140001 & 20011010 & 35.40 & 89.18 & \\
\hline & AST3A1 0110100457061507140001 & 20011010 & 34.86 & 89.03 & \\
\hline & *AST3A1 0307190456311507140001 & 20030719 & 35.90 & 87.97 & \\
\hline
\end{tabular}


Table A1. Cont.

\begin{tabular}{|c|c|c|c|c|c|}
\hline $\begin{array}{l}1^{\circ} \times 1^{\circ} \text { Tile's } \\
\text { South-Western Corner } \\
\text { (Latitude, Longitude) }\end{array}$ & $\begin{array}{l}\text { JSS Granule ID }{ }^{1,2} \text { of ASTER Product Used for } \\
\text { Mapping, Listed in the Order of Priority }\end{array}$ & $\begin{array}{l}\text { Observation Date } \\
\text { (yyyymmdd) }\end{array}$ & $\begin{array}{l}\text { Latitude at the } \\
\text { Scene Center }\left({ }^{\circ} \mathrm{N}\right)\end{array}$ & $\begin{array}{l}\text { Longitude at the } \\
\text { Scene Center }\left({ }^{\circ} \mathrm{E}\right)\end{array}$ & $\begin{array}{l}\text { Number of Products } \\
\text { (Number Redundant) } \\
\text { for Level-3A, Level-1B }\end{array}$ \\
\hline \multirow{10}{*}{$\left(36^{\circ} \mathrm{N}, 89^{\circ} \mathrm{E}\right)$} & *AST3A1 0309210456421507140001 & 20030921 & 36.15 & 90.06 & \multirow{10}{*}{$8(5), 2(0)$} \\
\hline & AST3A1 0309210457001507140001 & 20030921 & 35.09 & 89.75 & \\
\hline & AST3A1 0205130458481507140001 & 20020513 & 35.58 & 90.19 & \\
\hline & AST3A1 0309210456511507140001 & 20030921 & 35.62 & 89.90 & \\
\hline & *AST3A1 0110100456491507140001 & 20011010 & 35.93 & 89.32 & \\
\hline & ${ }^{*}$ AST3A1 0110100456581507140001 & 20011010 & 35.40 & 89.18 & \\
\hline & *AST3A1 0110100457061507140001 & 20011010 & 34.86 & 89.03 & \\
\hline & *AST3A1 0204110458281507140001 & 20020411 & 35.80 & 88.73 & \\
\hline & ASTL1B 0110100456490804080030 & 20011010 & 35.93 & 89.32 & \\
\hline & ASTL1B 0110100456580804230769 & 20011010 & 35.40 & 89.18 & \\
\hline \multirow{16}{*}{$\left(35^{\circ} \mathrm{N}, 84^{\circ} \mathrm{E}\right)$} & AST3A1 0011040529271206130018 & 20001104 & 34.52 & 85.26 & \multirow{16}{*}{$16(4), 0(0)$} \\
\hline & AST3A1 0011040529351206130050 & 20001104 & 33.99 & 85.10 & \\
\hline & *AST3A1 0111160514051206130022 & 20011116 & 34.85 & 84.49 & \\
\hline & AST3A1 0111160514141206130052 & 20011116 & 34.32 & 84.35 & \\
\hline & AST3A1 0111160514231206130053 & 20011116 & 33.79 & 84.28 & \\
\hline & AST3A1 0611210515251206130056 & 20061121 & 35.21 & 84.29 & \\
\hline & AST3A1 0611210515341206130023 & 20061121 & 34.68 & 84.14 & \\
\hline & AST3A1 0611210515421206130003 & 20061121 & 34.15 & 83.99 & \\
\hline & *AST3A1 0309030509141206130024 & 20030903 & 34.83 & 84.62 & \\
\hline & AST3A1 0309030509231206130027 & 20030903 & 34.30 & 84.48 & \\
\hline & AST3A1 0706100510041206130026 & 20070610 & 34.26 & 84.79 & \\
\hline & AST3A1 0706100510131206130011 & 20070610 & 33.73 & 84.65 & \\
\hline & *AST3A1 0310280515571507150001 & 20031028 & 35.10 & 85.07 & \\
\hline & AST3A1 0310280516061206130025 & 20031028 & 34.57 & 84.91 & \\
\hline & AST3A1 0612230515581206130007 & 20061223 & 34.13 & 84.18 & \\
\hline & *AST3A1 0103280526351507160001 & 20010328 & 35.22 & 84.24 & \\
\hline
\end{tabular}


Table A1. Cont.

\begin{tabular}{|c|c|c|c|c|c|}
\hline $\begin{array}{l}\quad 1^{\circ} \times 1^{\circ} \text { Tile's } \\
\text { South-Western Corner } \\
\text { (Latitude, Longitude) }\end{array}$ & $\begin{array}{l}\text { JSS Granule ID }{ }^{1,2} \text { of ASTER Product Used for } \\
\text { Mapping, Listed in the Order of Priority }\end{array}$ & $\begin{array}{l}\text { Observation Date } \\
\text { (yyyymmdd) }\end{array}$ & $\begin{array}{l}\text { Latitude at the } \\
\text { Scene Center }\left({ }^{\circ} \mathrm{N}\right)\end{array}$ & $\begin{array}{l}\text { Longitude at the } \\
\text { Scene Center }\left({ }^{\circ} \mathrm{E}\right)\end{array}$ & $\begin{array}{l}\text { Number of Products } \\
\text { (Number Redundant) } \\
\text { for Level-3A, Level-1B }\end{array}$ \\
\hline \multirow{11}{*}{$\left(35^{\circ} \mathrm{N}, 85^{\circ} \mathrm{E}\right)$} & AST3A1 0409050509261507150001 & 20040905 & 34.11 & 85.85 & \multirow{11}{*}{$11(5), 0(0)$} \\
\hline & AST3A1 0404050515481507150001 & 20040405 & 35.03 & 85.51 & \\
\hline & *AST3A1 0703060510091503130001 & 20070306 & 35.17 & 86.15 & \\
\hline & AST3A1 0703060510181503130001 & 20070306 & 34.64 & 86.00 & \\
\hline & *AST3A1 0011040529181507160001 & 20001104 & 35.04 & 85.42 & \\
\hline & *AST3A1 0011040529271206130018 & 20001104 & 34.52 & 85.26 & \\
\hline & *AST3A1 0011040529351206130050 & 20001104 & 33.99 & 85.10 & \\
\hline & AST3A1 0812050510281507150001 & 20081205 & 34.68 & 85.68 & \\
\hline & AST3A1 0812050510371507150001 & 20081205 & 34.15 & 85.53 & \\
\hline & *AST3A1 0310280515571507150001 & 20031028 & 35.10 & 85.07 & \\
\hline & AST3A1 0310280516061206130025 & 20031028 & 34.57 & 84.91 & \\
\hline \multirow{9}{*}{$\left(35^{\circ} \mathrm{N}, 86^{\circ} \mathrm{E}\right)$} & *AST3A1 0010280523201507140001 & 20001028 & 35.05 & 86.94 & \multirow{9}{*}{$9(4), 0(0)$} \\
\hline & AST3A1 0010280523281503130001 & 20001028 & 34.52 & 86.78 & \\
\hline & AST3A1 0010280523371503100001 & 20001028 & 33.99 & 86.63 & \\
\hline & AST3A1 0110240509101503100001 & 20011024 & 34.17 & 86.95 & \\
\hline & *AST3A1 0410230508441503130001 & 20041023 & 35.11 & 86.51 & \\
\hline & AST3A1 0410230508531503130001 & 20041023 & 34.58 & 86.35 & \\
\hline & AST3A1 0410230509021503130001 & 20041023 & 34.05 & 86.20 & \\
\hline & *AST3A1 0703060510091503130001 & 20070306 & 35.17 & 86.15 & \\
\hline & *AST3A1 0703060510181503130001 & 20070306 & 34.64 & 86.00 & \\
\hline \multirow{14}{*}{$\left(35^{\circ} \mathrm{N}, 87^{\circ} \mathrm{E}\right)$} & *AST3A1 0010280523201507140001 & 20001028 & 35.05 & 86.94 & \multirow{14}{*}{$14(5), 0(0)$} \\
\hline & *AST3A1 0010280523281503130001 & 20001028 & 34.52 & 86.78 & \\
\hline & *AST3A1 0010280523371503100001 & 20001028 & 33.99 & 86.63 & \\
\hline & *AST3A1 0510280456431504130001 & 20051028 & 34.86 & 87.53 & \\
\hline & AST3A1 0510280456521504130001 & 20051028 & 34.33 & 87.39 & \\
\hline & AST3A1 0510280457011504130001 & 20051028 & 33.79 & 87.25 & \\
\hline & AST3A1 0110080509281504130001 & 20011008 & 34.53 & 88.26 & \\
\hline & AST3A1 0110080509371504130001 & 20011008 & 34.00 & 88.10 & \\
\hline & AST3A1 0511200502481504130001 & 20051120 & 35.24 & 87.23 & \\
\hline & AST3A1 0511200502571504130001 & 20051120 & 34.71 & 87.08 & \\
\hline & AST3A1 0511200503061504130001 & 20051120 & 34.17 & 86.93 & \\
\hline & *AST3A1 0709160457481504130001 & 20070916 & 34.81 & 87.90 & \\
\hline & AST3A1 0709160457571504130001 & 20070916 & 34.28 & 87.75 & \\
\hline & AST3A1 0709160458061507200001 & 20070916 & 33.75 & 87.60 & \\
\hline
\end{tabular}


Table A1. Cont.

\begin{tabular}{|c|c|c|c|c|c|}
\hline $\begin{array}{l}1^{\circ} \times 1^{\circ} \text { Tile's }^{\prime} \\
\text { South-Western Corner } \\
\text { (Latitude, Longitude) }\end{array}$ & $\begin{array}{l}\text { JSS Granule ID }{ }^{1,2} \text { of ASTER Product Used for } \\
\text { Mapping, Listed in the Order of Priority }\end{array}$ & $\begin{array}{l}\text { Observation Date } \\
\text { (yyyymmdd) }\end{array}$ & $\begin{array}{l}\text { Latitude at the } \\
\text { Scene Center }\left({ }^{\circ} \mathrm{N}\right)\end{array}$ & $\begin{array}{l}\text { Longitude at the } \\
\text { Scene Center }\left({ }^{\circ} \mathrm{E}\right)\end{array}$ & $\begin{array}{l}\text { Number of Products } \\
\text { (Number Redundant) } \\
\text { for Level-3A, Level-1B }\end{array}$ \\
\hline \multirow{9}{*}{$\left(35^{\circ} \mathrm{N}, 88^{\circ} \mathrm{E}\right)$} & AST3A1 0110080509191504130001 & 20011008 & 35.06 & 88.41 & \multirow{9}{*}{$9(4), 0(0)$} \\
\hline & *AST3A1 0110080509281504130001 & 20011008 & 34.52 & 86.78 & \\
\hline & *AST3A1 0110080509371504130001 & 20011008 & 33.99 & 86.63 & \\
\hline & AST3A1 0010300511001507140001 & 20001030 & 34.69 & 88.74 & \\
\hline & AST3A1 0010300511091507140001 & 20001030 & 34.16 & 88.59 & \\
\hline & *AST3A1 0110100457061507140001 & 20011010 & 34.86 & 89.03 & \\
\hline & AST3A1 0110100457151507140001 & 20011010 & 34.33 & 88.89 & \\
\hline & AST3A1 0110100457241507140001 & 20011010 & 33.80 & 88.75 & \\
\hline & *AST3A1 0403310457341507140001 & 20040331 & 34.79 & 88.05 & \\
\hline \multirow{9}{*}{$\left(35^{\circ} \mathrm{N}, 89^{\circ} \mathrm{E}\right)$} & *AST3A1 0309210457001507140001 & 20030921 & 35.09 & 89.75 & \multirow{9}{*}{$9(4), 0(0)$} \\
\hline & AST3A1 0309210457091507140001 & 20030921 & 34.56 & 89.59 & \\
\hline & AST3A1 0205130458571507140001 & 20020513 & 35.05 & 90.03 & \\
\hline & AST3A1 0205130459061507140001 & 20020513 & 34.52 & 89.87 & \\
\hline & *AST3A1 0110100457061507140001 & 20011010 & 34.86 & 89.03 & \\
\hline & *AST3A1 0110100457151507140001 & 20011010 & 34.33 & 88.89 & \\
\hline & *AST3A1 0110100457241507140001 & 20011010 & 33.80 & 88.75 & \\
\hline & AST3A1 0010070505311507200001 & 20001007 & 34.17 & 90.09 & \\
\hline & AST3A1 0309210457171507200001 & 20030921 & 34.03 & 89.43 & \\
\hline \multirow{9}{*}{$\left(34^{\circ} \mathrm{N}, 84^{\circ} \mathrm{E}\right)$} & AST3A1 0405070516211206130005 & 20040507 & 34.05 & 84.71 & \multirow{9}{*}{$9(2), 0(0)$} \\
\hline & AST3A1 0405070516301206130004 & 20040507 & 33.52 & 84.56 & \\
\hline & AST3A1 0405070516391206120016 & 20040507 & 32.99 & 84.40 & \\
\hline & *AST3A1 0011040529351206130050 & 20001104 & 33.99 & 85.10 & \\
\hline & AST3A1 0011040529441206130051 & 20001104 & 33.46 & 84.95 & \\
\hline & AST3A1 0011040529531504240001 & 20001104 & 32.93 & 84.80 & \\
\hline & *AST3A1 0111160514231206130053 & 20011116 & 33.79 & 84.21 & \\
\hline & AST3A1 0111160514321206120049 & 20011116 & 33.26 & 84.07 & \\
\hline & AST3A1 0111160514401206120015 & 20011116 & 32.72 & 83.94 & \\
\hline
\end{tabular}


Table A1. Cont.

\begin{tabular}{|c|c|c|c|c|c|}
\hline $\begin{array}{l}\mathbf{1}^{\circ} \times \mathbf{1}^{\circ} \text { Tile's }^{\prime} \\
\text { South-Western Corner } \\
\text { (Latitude, Longitude) }\end{array}$ & $\begin{array}{l}\text { JSS Granule ID }{ }^{1,2} \text { of ASTER Product Used for } \\
\text { Mapping, Listed in the Order of Priority }\end{array}$ & $\begin{array}{l}\text { Observation Date } \\
\text { (yyyymmdd) }\end{array}$ & $\begin{array}{c}\text { Latitude at the } \\
\text { Scene Center }\left({ }^{\circ} \mathrm{N}\right)\end{array}$ & $\begin{array}{l}\text { Longitude at the } \\
\text { Scene Center }\left({ }^{\circ} \mathrm{E}\right)\end{array}$ & $\begin{array}{l}\text { Number of Products } \\
\text { (Number Redundant) } \\
\text { for Level-3A, Level-1B }\end{array}$ \\
\hline \multirow{10}{*}{$\left(34^{\circ} \mathrm{N}, 85^{\circ} \mathrm{E}\right)$} & *AST3A1 0409050509261507150001 & 20040905 & 34.11 & 85.85 & \multirow{10}{*}{$10(4), 0(0)$} \\
\hline & AST3A1 0409050509351507150001 & 20040905 & 33.58 & 85.70 & \\
\hline & AST3A1 0409050509441503090001 & 20040905 & 33.05 & 85.55 & \\
\hline & *AST3A1 0011040529351206130050 & 20001104 & 33.99 & 85.10 & \\
\hline & *AST3A1 0011040529441206130051 & 20001104 & 33.46 & 84.95 & \\
\hline & AST3A1 0410230509111507150001 & 20041023 & 33.52 & 86.04 & \\
\hline & AST3A1 0410230509191503090001 & 20041023 & 32.99 & 85.89 & \\
\hline & *AST3A1 0812050510371507150001 & 20081205 & 34.15 & 85.53 & \\
\hline & AST3A1 0812050510461206130014 & 20081205 & 33.62 & 85.38 & \\
\hline & AST3A1 0812050510551504240001 & 20081205 & 33.09 & 85.23 & \\
\hline \multirow{13}{*}{$\left(34^{\circ} \mathrm{N}, 86^{\circ} \mathrm{E}\right)$} & *AST3A1 0409050509261507150001 & 20040905 & 34.11 & 85.85 & \multirow{13}{*}{$13(7), 0(0)$} \\
\hline & *AST3A1 0409050509351507150001 & 20040905 & 33.58 & 85.70 & \\
\hline & *AST3A1 0410230509021503130001 & 20041023 & 34.05 & 86.20 & \\
\hline & *AST3A1 0410230509111507150001 & 20041023 & 33.52 & 86.04 & \\
\hline & *AST3A1 0410230509191503090001 & 20041023 & 32.99 & 85.89 & \\
\hline & *AST3A1 0010280523371503100001 & 20001028 & 33.99 & 86.63 & \\
\hline & AST3A1 0010280523461503100001 & 20001028 & 33.46 & 86.47 & \\
\hline & AST3A1 0010280523551503090001 & 20001028 & 32.93 & 86.32 & \\
\hline & *AST3A1 0110240509101503100001 & 20011024 & 34.17 & 86.95 & \\
\hline & AST3A1 0110240509191503100001 & 20011024 & 33.64 & 86.80 & \\
\hline & AST3A1 0110240509281503090001 & 20011024 & 33.11 & 86.65 & \\
\hline & AST3A1 0510280457101503090001 & 20051028 & 33.26 & 87.11 & \\
\hline & AST3A1 0510280457181503090001 & 20051028 & 32.73 & 86.97 & \\
\hline
\end{tabular}


Table A1. Cont.

\begin{tabular}{|c|c|c|c|c|c|}
\hline $\begin{array}{l}\quad 1^{\circ} \times 1^{\circ} \text { Tile's } \\
\text { South-Western Corner } \\
\text { (Latitude, Longitude) }\end{array}$ & $\begin{array}{l}\text { JSS Granule ID }{ }^{1,2} \text { of ASTER Product Used for } \\
\text { Mapping, Listed in the Order of Priority }\end{array}$ & $\begin{array}{l}\text { Observation Date } \\
\text { (yyyymmdd) }\end{array}$ & $\begin{array}{l}\text { Latitude at the } \\
\text { Scene Center }\left({ }^{\circ} \mathrm{N}\right)\end{array}$ & $\begin{array}{l}\text { Longitude at the } \\
\text { Scene Center }\left({ }^{\circ} \mathrm{E}\right)\end{array}$ & $\begin{array}{l}\text { Number of Products } \\
\text { (Number Redundant) } \\
\text { for Level-3A, Level-1B }\end{array}$ \\
\hline$\left(34^{\circ} \mathrm{N}, 87^{\circ} \mathrm{E}\right)$ & $\begin{array}{l}\text { *AST3A1 } 0110080509371504130001 \\
\text { *AST3A1 } 0110240509101503100001 \\
\text { *AST3A1 } 0110240509191503100001 \\
\text { *AST3A1 } 0110240509281503090001 \\
\text { AST3A1 0204110459121504150001 } \\
\text { *AST3A1 0510280457011504130001 } \\
\text { *AST3A1 0510280457101503090001 } \\
\text { *AST3A1 0510280457181503090001 } \\
\text { AST3A1 0110080509541507100001 } \\
\text { AST3A1 0703080458051507100001 } \\
\text { AST3A1 0703080458141507100001 } \\
\text { AST3A1 0703080458231504150001 } \\
\text { AST3A1 0709160458151504150001 } \\
\text { *AST3A1 0709160457571504130001 } \\
\text { AST3A1 0110080509451507100001 } \\
\text { *AST3A1 0709160458061507300001 }\end{array}$ & $\begin{array}{l}20011008 \\
20011024 \\
20011024 \\
20011024 \\
20020411 \\
20051028 \\
20051028 \\
20051028 \\
20011008 \\
20070308 \\
20070308 \\
20070308 \\
20070916 \\
20070916 \\
20011008 \\
20070916\end{array}$ & $\begin{array}{l}34.00 \\
34.17 \\
33.64 \\
33.11 \\
33.14 \\
33.79 \\
33.26 \\
32.73 \\
32.94 \\
34.22 \\
33.69 \\
33.15 \\
33.21 \\
34.28 \\
33.47 \\
33.75\end{array}$ & $\begin{array}{l}88.10 \\
86.95 \\
86.80 \\
86.65 \\
87.99 \\
87.25 \\
87.11 \\
86.97 \\
87.80 \\
88.18 \\
88.04 \\
87.89 \\
87.47 \\
87.75 \\
87.95 \\
87.60\end{array}$ & $16(9), 0(0)$ \\
\hline$\left(34^{\circ} \mathrm{N}, 88^{\circ} \mathrm{E}\right)$ & $\begin{array}{l}\text { *AST3A1 } 0703080458051507100001 \\
\text { *AST3A1 } 0703080458141507100001 \\
\text { *AST3A1 } 0703080458231504150001 \\
\text { AST3A1 0309210457261507100001 } \\
\text { AST3A1 0309210457351507100001 } \\
\text { *AST3A1 } 0110100457241507140001 \\
\text { AST3A1 } 0110100457331507010001 \\
\text { AST3A1 0110100457421507010001 } \\
\text { *AST3A1 } 0204110459121504150001 \\
\text { *AST3A1 } 0010300511091507140001 \\
\text { AST3A1 0010300511181507100001 }\end{array}$ & $\begin{array}{l}20070308 \\
20070308 \\
20070308 \\
20030921 \\
20030921 \\
20011010 \\
20011010 \\
20011010 \\
20020411 \\
20001030 \\
20001030\end{array}$ & $\begin{array}{l}34.22 \\
33.69 \\
33.15 \\
33.50 \\
32.97 \\
33.80 \\
33.27 \\
32.74 \\
33.14 \\
34.16 \\
33.63\end{array}$ & $\begin{array}{l}88.18 \\
88.04 \\
87.89 \\
89.28 \\
89.13 \\
88.75 \\
88.61 \\
88.48 \\
87.99 \\
88.59 \\
88.44\end{array}$ & $11(6), 0(0)$ \\
\hline
\end{tabular}


Table A1. Cont.

\begin{tabular}{|c|c|c|c|c|c|}
\hline $\begin{array}{l}1^{\circ} \times 1^{\circ} \text { Tile's }^{\prime} \\
\text { South-Western Corner } \\
\text { (Latitude, Longitude) }\end{array}$ & $\begin{array}{l}\text { JSS Granule ID }{ }^{1,2} \text { of ASTER Product Used for } \\
\text { Mapping, Listed in the Order of Priority }\end{array}$ & $\begin{array}{l}\text { Observation Date } \\
\text { (yyyymmdd) }\end{array}$ & $\begin{array}{l}\text { Latitude at the } \\
\text { Scene Center }\left({ }^{\circ} \mathrm{N}\right)\end{array}$ & $\begin{array}{l}\text { Longitude at the } \\
\text { Scene Center }\left({ }^{\circ} \mathrm{E}\right)\end{array}$ & $\begin{array}{l}\text { Number of Products } \\
\text { (Number Redundant) } \\
\text { for Level-3A, Level-1B }\end{array}$ \\
\hline \multirow{9}{*}{$\left(34^{\circ} \mathrm{N}, 89^{\circ} \mathrm{E}\right)$} & *AST3A1 0309210457261507100001 & 20030921 & 33.50 & 89.28 & \multirow{9}{*}{$9(6), 0(0)$} \\
\hline & *AST3A1 0309210457351507100001 & 20030921 & 32.97 & 89.13 & \\
\hline & *AST3A1 0110100457241507140001 & 20011010 & 33.80 & 88.75 & \\
\hline & *AST3A1 0110100457331507010001 & 20011010 & 33.27 & 88.61 & \\
\hline & AST3A1 0010070505481507070001 & 20001007 & 33.10 & 89.80 & \\
\hline & AST3A1 0108140505431507070001 & 20010814 & 32.96 & 89.24 & \\
\hline & *AST3A1 0010070505311507300001 & 20001007 & 34.17 & 90.09 & \\
\hline & AST3A1 0010070505401507300001 & 20001007 & 33.63 & 89.95 & \\
\hline & *AST3A1 0309210457171507300001 & 20030921 & 34.03 & 89.43 & \\
\hline \multirow{10}{*}{$\left(33^{\circ} \mathrm{N}, 84^{\circ} \mathrm{E}\right)$} & *AST3A1 0405070516391206120016 & 20040507 & 32.99 & 84.40 & \multirow{10}{*}{$10(4), 0(0)$} \\
\hline & AST3A1 0405070516471206120018 & 20040507 & 32.46 & 84.26 & \\
\hline & AST3A1 0405070516561206120019 & 20040507 & 31.93 & 84.11 & \\
\hline & *AST3A1 0011040529531504240001 & 20001104 & 32.93 & 84.80 & \\
\hline & AST3A1 0011040530021206120046 & 20001104 & 32.40 & 84.64 & \\
\hline & AST3A1 0011040530111206120041 & 20001104 & 31.87 & 84.49 & \\
\hline & *AST3A1 0111160514321206120049 & 20011116 & 33.26 & 84.07 & \\
\hline & *AST3A1 0111160514401206120015 & 20011116 & 32.72 & 83.94 & \\
\hline & AST3A1 0210020511441504240001 & 20021002 & 32.57 & 85.06 & \\
\hline & AST3A1 0210020511531504240001 & 20021002 & 32.04 & 84.91 & \\
\hline \multirow{11}{*}{$\left(33^{\circ} \mathrm{N}, 85^{\circ} \mathrm{E}\right)$} & *AST3A1 0409050509441503090001 & 20040905 & 33.05 & 85.55 & \multirow{11}{*}{$11(4), 0(0)$} \\
\hline & AST3A1 0409050509531504240001 & 20040905 & 32.52 & 85.40 & \\
\hline & AST3A1 0409050510021504240001 & 20040905 & 31.98 & 85.26 & \\
\hline & *AST3A1 0011040529531504240001 & 20001104 & 32.93 & 84.80 & \\
\hline & *AST3A1 0011040530021206120046 & 20001104 & 32.40 & 84.64 & \\
\hline & AST3A1 0310140504091503090001 & 20031014 & 33.20 & 86.04 & \\
\hline & AST3A1 0310140504181503090001 & 20031014 & 32.67 & 85.89 & \\
\hline & AST3A1 0310140504271504240001 & 20031014 & 32.14 & 85.75 & \\
\hline & AST3A1 0210020511351504240001 & 20021002 & 33.10 & 85.20 & \\
\hline & AST3A1 0812050511031504240001 & 20081205 & 32.56 & 85.09 & \\
\hline & *AST3A1 0210020511531504240001 & 20021002 & 32.04 & 84.91 & \\
\hline
\end{tabular}


Table A1. Cont.

\begin{tabular}{|c|c|c|c|c|c|}
\hline $\begin{array}{l}\mathbf{1}^{\circ} \times \mathbf{1}^{\circ} \text { Tile's }^{\prime} \\
\text { South-Western Corner } \\
\text { (Latitude, Longitude) }\end{array}$ & $\begin{array}{l}\text { JSS Granule ID }{ }^{1,2} \text { of ASTER Product Used for } \\
\text { Mapping, Listed in the Order of Priority }\end{array}$ & $\begin{array}{l}\text { Observation Date } \\
\text { (yyyymmdd) }\end{array}$ & $\begin{array}{l}\text { Latitude at the } \\
\text { Scene Center }\left({ }^{\circ} \mathrm{N}\right)\end{array}$ & $\begin{array}{l}\text { Longitude at the } \\
\text { Scene Center }\left({ }^{\circ} \mathrm{E}\right)\end{array}$ & $\begin{array}{l}\text { Number of Products } \\
\text { (Number Redundant) } \\
\text { for Level-3A, Level-1B }\end{array}$ \\
\hline \multirow{10}{*}{$\left(33^{\circ} \mathrm{N}, 86^{\circ} \mathrm{E}\right)$} & *AST3A1 0110240509281503090001 & 20011024 & 33.11 & 86.65 & \multirow{10}{*}{$10(4), 0(0)$} \\
\hline & AST3A1 0110240509451502060001 & 20011024 & 32.05 & 86.37 & \\
\hline & *AST3A1 0010280523551503090001 & 20001028 & 32.93 & 86.32 & \\
\hline & AST3A1 0010280524041503090001 & 20001028 & 32.40 & 86.17 & \\
\hline & AST3A1 0010280524131502060001 & 20001028 & 31.87 & 86.02 & \\
\hline & AST3A1 0610310457291503090001 & 20061031 & 32.71 & 87.10 & \\
\hline & AST3A1 0610310457371502060001 & 20061031 & 32.18 & 86.96 & \\
\hline & *AST3A1 0310140504091503090001 & 20031014 & 33.20 & 86.04 & \\
\hline & *AST3A1 0310140504181503090001 & 20031014 & 32.67 & 85.89 & \\
\hline & AST3A1 0110240509361507300001 & 20011024 & 32.58 & 86.51 & \\
\hline \multirow{18}{*}{$\left(33^{\circ} \mathrm{N}, 87^{\circ} \mathrm{E}\right)$} & AST3A1 0010300511271507010001 & 20001030 & 33.10 & 88.30 & \multirow{18}{*}{$14(5), 4(0)$} \\
\hline & AST3A1 0010300511361507010001 & 20001030 & 32.57 & 88.15 & \\
\hline & AST3A1 0010300511441507010001 & 20001030 & 32.03 & 88.01 & \\
\hline & *AST3A1 0204110459121504150001 & 20020411 & 33.14 & 87.99 & \\
\hline & AST3A1 0204110459211504150001 & 20020411 & 32.61 & 87.85 & \\
\hline & AST3A1 0204110459291504150001 & 20020411 & 32.08 & 87.71 & \\
\hline & *AST3A1 0610310457291503090001 & 20061031 & 32.71 & 87.10 & \\
\hline & *AST3A1 0610310457371502060001 & 20061031 & 32.18 & 86.96 & \\
\hline & *AST3A1 0703080458231504150001 & 20070308 & 33.15 & 87.89 & \\
\hline & AST3A1 0703080458321504150001 & 20070308 & 32.62 & 87.75 & \\
\hline & AST3A1 0703080458411504150001 & 20070308 & 32.09 & 87.61 & \\
\hline & *AST3A1 0510280457101503090001 & 20051028 & 33.26 & 87.11 & \\
\hline & AST3A1 0203100459251504150001 & 20020310 & 33.20 & 87.56 & \\
\hline & AST3A1 0802140504341502060001 & 20080214 & 31.92 & 87.23 & \\
\hline & ASTL1B 0610310457290805130011 & 20061031 & 32.71 & 87.10 & \\
\hline & ASTL1B 0610310457370710020037 & 20061031 & 32.18 & 86.96 & \\
\hline & ASTL1B 0703080458320710300069 & 20070308 & 32.62 & 87.75 & \\
\hline & ASTL1B 0703080458410710020025 & 20070308 & 32.09 & 87.61 & \\
\hline
\end{tabular}


Table A1. Cont.

\begin{tabular}{|c|c|c|c|c|c|}
\hline $\begin{array}{l}1^{\circ} \times 1^{\circ} \text { Tile's } \\
\text { South-Western Corner } \\
\text { (Latitude, Longitude) }\end{array}$ & $\begin{array}{l}\text { JSS Granule ID }{ }^{1,2} \text { of ASTER Product Used for } \\
\text { Mapping, Listed in the Order of Priority }\end{array}$ & $\begin{array}{l}\text { Observation Date } \\
\text { (yyyymmdd) }\end{array}$ & $\begin{array}{l}\text { Latitude at the } \\
\text { Scene Center }\left({ }^{\circ} \mathrm{N}\right)\end{array}$ & $\begin{array}{l}\text { Longitude at the } \\
\text { Scene Center }\left({ }^{\circ} \mathrm{E}\right)\end{array}$ & $\begin{array}{l}\text { Number of Products } \\
\text { (Number Redundant) } \\
\text { for Level-3A, Level-1B }\end{array}$ \\
\hline \multirow{10}{*}{$\left(33^{\circ} \mathrm{N}, 88^{\circ} \mathrm{E}\right)$} & *AST3A1 0108140505431507070001 & 20010814 & 32.96 & 89.24 & \multirow{10}{*}{$10(6), 0(0)$} \\
\hline & *AST3A1 0010300511271507010001 & 20001030 & 33.10 & 88.30 & \\
\hline & *AST3A1 0010300511361507010001 & 20001030 & 32.57 & 88.15 & \\
\hline & *AST3A1 0010300511441507010001 & 20001030 & 32.03 & 88.01 & \\
\hline & AST3A1 0610080451081507010001 & 20061008 & 33.19 & 89.19 & \\
\hline & AST3A1 0610080451171507010001 & 20061008 & 32.66 & 89.05 & \\
\hline & AST3A1 0610080451261507010001 & 20061008 & 32.13 & 88.91 & \\
\hline & *AST3A1 0110100457331507010001 & 20011010 & 33.27 & 88.61 & \\
\hline & *AST3A1 0110100457421507010001 & 20011010 & 32.74 & 88.48 & \\
\hline & AST3A1 0110100457511507010001 & 20011010 & 32.20 & 88.34 & \\
\hline \multirow{8}{*}{$\left(33^{\circ} \mathrm{N}, 89^{\circ} \mathrm{E}\right)$} & *AST3A1 0010070505481507070001 & 20001007 & 33.10 & 89.80 & \multirow{8}{*}{$8(2), 0(0)$} \\
\hline & AST3A1 0010070505571507070001 & 20001007 & 32.57 & 89.65 & \\
\hline & AST3A1 0010070506061507070001 & 20001007 & 32.04 & 89.51 & \\
\hline & AST3A1 0011010459061507070001 & 20001101 & 32.75 & 90.14 & \\
\hline & AST3A1 0011010459151507070001 & 20001101 & 32.19 & 90.01 & \\
\hline & *AST3A1 0108140505431507070001 & 20010814 & 32.96 & 89.24 & \\
\hline & AST3A1 0108140505521507070001 & 20010814 & 32.43 & 89.09 & \\
\hline & AST3A1 0108140506011507070001 & 20010814 & 31.90 & 88.94 & \\
\hline \multirow{10}{*}{$\left(32^{\circ} \mathrm{N}, 84^{\circ} \mathrm{E}\right)$} & *AST3A1 0210020511531504240001 & 20021002 & 32.04 & 84.91 & \multirow{10}{*}{$10(3), 0(0)$} \\
\hline & AST3A1 0210020512021206180059 & 20021002 & 31.50 & 84.77 & \\
\hline & AST3A1 0210020512101507100001 & 20021002 & 30.97 & 84.63 & \\
\hline & *AST3A1 0011040530111206120041 & 20001104 & 31.87 & 84.49 & \\
\hline & AST3A1 0011040530201206180060 & 20001104 & 31.34 & 84.35 & \\
\hline & AST3A1 0011040530280907220502 & 20001104 & 30.81 & 84.20 & \\
\hline & *AST3A1 0405070516561206120019 & 20040507 & 31.93 & 84.11 & \\
\hline & AST3A1 0405070517051206180056 & 20040507 & 31.39 & 83.95 & \\
\hline & AST3A1 0801040511041507130001 & 20080104 & 30.92 & 85.01 & \\
\hline & AST3A1 0801040510551507130001 & 20080104 & 31.45 & 85.15 & \\
\hline
\end{tabular}


Table A1. Cont.

\begin{tabular}{|c|c|c|c|c|c|}
\hline $\begin{array}{l}\quad \mathbf{1}^{\circ} \times \mathbf{1}^{\circ} \text { Tile's }^{\prime} \\
\text { South-Western Corner } \\
\text { (Latitude, Longitude) }\end{array}$ & $\begin{array}{l}\text { JSS Granule ID }{ }^{1,2} \text { of ASTER Product Used for } \\
\text { Mapping, Listed in the Order of Priority }\end{array}$ & $\begin{array}{l}\text { Observation Date } \\
\text { (yyyymmdd) }\end{array}$ & $\begin{array}{l}\text { Latitude at the } \\
\text { Scene Center }\left({ }^{\circ} \mathrm{N}\right)\end{array}$ & $\begin{array}{l}\text { Longitude at the } \\
\text { Scene Center }\left({ }^{\circ} \mathrm{E}\right)\end{array}$ & $\begin{array}{l}\text { Number of Products } \\
\text { (Number Redundant) } \\
\text { for Level-3A, Level-1B }\end{array}$ \\
\hline \multirow{13}{*}{$\left(32^{\circ} \mathrm{N}, 85^{\circ} \mathrm{E}\right)$} & *AST3A1 0110240509451502060001 & 20011024 & 32.05 & 86.37 & \multirow{13}{*}{$13(4), 0(0)$} \\
\hline & AST3A1 0110240509541502060001 & 20011024 & 31.52 & 86.22 & \\
\hline & *AST3A1 0210020511531504240001 & 20021002 & 32.04 & 84.91 & \\
\hline & AST3A1 0303040505241507090001 & 20030304 & 30.96 & 86.24 & \\
\hline & AST3A1 0711010510231502060001 & 20071101 & 31.92 & 85.70 & \\
\hline & AST3A1 0711010510411206180010 & 20071101 & 30.86 & 85.40 & \\
\hline & AST3A1 0803010504371502060001 & 20080301 & 31.55 & 86.01 & \\
\hline & AST3A1 1111280510151502060001 & 20111128 & 31.32 & 85.97 & \\
\hline & AST3A1 1111280510241502060001 & 20111128 & 30.79 & 85.82 & \\
\hline & AST3A1 0703060511021504240001 & 20070306 & 31.99 & 85.25 & \\
\hline & *AST3A1 0801040511041507130001 & 20080104 & 30.92 & 85.01 & \\
\hline & *AST3A1 0801040510551507130001 & 20080104 & 31.45 & 85.15 & \\
\hline & AST3A1 0403130511131507130001 & 20040313 & 31.40 & 85.50 & \\
\hline \multirow{9}{*}{$\left(32^{\circ} \mathrm{N}, 86^{\circ} \mathrm{E}\right)$} & *AST3A1 0711010510231502060001 & 20071101 & 31.92 & 85.70 & \multirow{9}{*}{$9(3), 0(0)$} \\
\hline & AST3A1 0202220459591502060001 & 20020222 & 32.20 & 86.86 & \\
\hline & AST3A1 0202220500081502060001 & 20020222 & 31.66 & 86.73 & \\
\hline & AST3A1 0202220500171502060001 & 20020222 & 31.13 & 86.59 & \\
\hline & *AST3A1 0110240509451502060001 & 20011024 & 32.05 & 86.37 & \\
\hline & *AST3A1 0110240509541502060001 & 20011024 & 31.52 & 86.22 & \\
\hline & AST3A1 0110240510031502060001 & 20011024 & 30.99 & 86.08 & \\
\hline & AST3A1 0203100459511502060001 & 20020310 & 31.61 & 87.15 & \\
\hline & AST3A1 0203100500001502060001 & 20020310 & 31.07 & 87.01 & \\
\hline
\end{tabular}


Table A1. Cont.

\begin{tabular}{|c|c|c|c|c|c|}
\hline $\begin{array}{l}\mathbf{1}^{\circ} \times \mathbf{1}^{\circ} \text { Tile's }^{\prime} \\
\text { South-Western Corner } \\
\text { (Latitude, Longitude) }\end{array}$ & $\begin{array}{l}\text { JSS Granule ID }{ }^{1,2} \text { of ASTER Product Used for } \\
\text { Mapping, Listed in the Order of Priority }\end{array}$ & $\begin{array}{l}\text { Observation Date } \\
\text { (yyyymmdd) }\end{array}$ & $\begin{array}{l}\text { Latitude at the } \\
\text { Scene Center }\left({ }^{\circ} \mathrm{N}\right)\end{array}$ & $\begin{array}{l}\text { Longitude at the } \\
\text { Scene Center }\left({ }^{\circ} \mathrm{E}\right)\end{array}$ & $\begin{array}{l}\text { Number of Products } \\
\text { (Number Redundant) } \\
\text { for Level-3A, Level-1B }\end{array}$ \\
\hline \multirow{13}{*}{$\left(32^{\circ} \mathrm{N}, 87^{\circ} \mathrm{E}\right)$} & *AST3A1 0010300511441507010001 & 20001030 & 32.03 & 88.01 & \multirow{13}{*}{$13(3), 0(0)$} \\
\hline & *AST3A1 0204110459291504150001 & 20020411 & 32.08 & 87.71 & \\
\hline & AST3A1 0602240503491502060001 & 20060224 & 30.85 & 86.98 & \\
\hline & AST3A1 0203100459431502060001 & 20020310 & 32.14 & 87.28 & \\
\hline & AST3A1 0803100458201502060001 & 20080310 & 31.60 & 87.22 & \\
\hline & AST3A1 0803100458291502060001 & 20080310 & 31.06 & 87.08 & \\
\hline & *AST3A1 0802140504341502060001 & 20080214 & 31.92 & 87.23 & \\
\hline & AST3A1 0210040459451507080001 & 20021004 & 31.02 & 87.37 & \\
\hline & AST3A1 0110100458001507080001 & 20011010 & 31.67 & 88.20 & \\
\hline & AST3A1 0110100458081507080001 & 20011010 & 31.14 & 88.07 & \\
\hline & AST3A1 0010300512021507300001 & 20001030 & 30.97 & 87.73 & \\
\hline & AST3A1 0010300511531507300001 & 20001030 & 31.50 & 87.87 & \\
\hline & AST3A1 0802070458341507300001 & 20080207 & 31.55 & 87.52 & \\
\hline \multirow{9}{*}{$\left(32^{\circ} \mathrm{N}, 88^{\circ} \mathrm{E}\right)$} & *AST3A1 0110100457511507010001 & 20011010 & 32.20 & 88.34 & \multirow{9}{*}{$9(3), 0(0)$} \\
\hline & *AST3A1 0110100458001507080001 & 20011010 & 31.67 & 88.20 & \\
\hline & *AST3A1 0110100458081507080001 & 20011010 & 31.14 & 88.07 & \\
\hline & AST3A1 0711030457591507080001 & 20071103 & 31.92 & 88.80 & \\
\hline & AST3A1 0711030458081507080001 & 20071103 & 31.39 & 88.65 & \\
\hline & AST3A1 0711030458171507080001 & 20071103 & 30.86 & 88.51 & \\
\hline & AST3A1 0201050501061507080001 & 20020105 & 31.87 & 89.10 & \\
\hline & AST3A1 0201050501141507080001 & 20020105 & 31.34 & 88.95 & \\
\hline & AST3A1 0201050501231507080001 & 20020105 & 30.81 & 88.80 & \\
\hline \multirow{10}{*}{$\left(32^{\circ} \mathrm{N}, 89^{\circ} \mathrm{E}\right)$} & *AST3A1 0711030457591507080001 & 20071103 & 31.92 & 88.80 & \multirow{10}{*}{$10(3), 0(0)$} \\
\hline & *AST3A1 0711030458081507080001 & 20071103 & 31.39 & 88.65 & \\
\hline & *AST3A1 0011010459151507070001 & 20001101 & 32.19 & 90.01 & \\
\hline & AST3A1 0011010459241507090001 & 20001101 & 31.66 & 89.87 & \\
\hline & AST3A1 0403010446481507080001 & 20040301 & 31.08 & 90.04 & \\
\hline & AST3A1 0202150453501507090001 & 20020215 & 31.44 & 89.81 & \\
\hline & AST3A1 0202150453591507080001 & 20020215 & 30.91 & 89.67 & \\
\hline & AST3A1 0111270456181507090001 & 20011127 & 32.05 & 89.46 & \\
\hline & AST3A1 0111270456271507090001 & 20011127 & 31.52 & 89.32 & \\
\hline & AST3A1 0111270456361507090001 & 20011127 & 30.99 & 89.18 & \\
\hline
\end{tabular}


Table A1. Cont.

\begin{tabular}{|c|c|c|c|c|c|}
\hline $\begin{array}{l}\mathbf{1}^{\circ} \times \mathbf{1}^{\circ} \text { Tile's }^{\prime} \\
\text { South-Western Corner } \\
\text { (Latitude, Longitude) }\end{array}$ & $\begin{array}{l}\text { JSS Granule ID }{ }^{1,2} \text { of ASTER Product Used for } \\
\text { Mapping, Listed in the Order of Priority }\end{array}$ & $\begin{array}{l}\text { Observation Date } \\
\text { (yyyymmdd) }\end{array}$ & $\begin{array}{c}\text { Latitude at the } \\
\text { Scene Center }\left({ }^{\circ} \mathrm{N}\right)\end{array}$ & $\begin{array}{l}\text { Longitude at the } \\
\text { Scene Center }\left({ }^{\circ} \mathrm{E}\right)\end{array}$ & $\begin{array}{l}\text { Number of Products } \\
\text { (Number Redundant) } \\
\text { for Level-3A, Level-1B }\end{array}$ \\
\hline \multirow{12}{*}{$\left(31^{\circ} \mathrm{N}, 84^{\circ} \mathrm{E}\right)$} & AST3A1 0711010510491204260040 & 20071101 & 30.33 & 85.26 & \multirow{12}{*}{$12(2), 0(0)$} \\
\hline & AST3A1 0711010510581204260045 & 20071101 & 29.80 & 85.12 & \\
\hline & *AST3A1 0801040511041507130001 & 20080104 & 30.92 & 85.01 & \\
\hline & AST3A1 0012150523351206150026 & 20001215 & 30.97 & 84.65 & \\
\hline & AST3A1 0701170511021507100001 & 20070117 & 30.92 & 85.00 & \\
\hline & AST3A1 0701170511101507100001 & 20070117 & 30.39 & 84.85 & \\
\hline & AST3A1 0701170511191004160020 & 20070117 & 29.86 & 84.71 & \\
\hline & AST3A1 0210020512191507100001 & 20021002 & 30.44 & 84.49 & \\
\hline & AST3A1 0210020512281004140507 & 20021002 & 29.91 & 84.35 & \\
\hline & *AST3A1 0011040530280907220502 & 20001104 & 30.81 & 84.20 & \\
\hline & AST3A1 0011040530370907220503 & 20001104 & 30.27 & 84.05 & \\
\hline & AST3A1 0011040530460907220504 & 20001104 & 29.74 & 83.91 & \\
\hline \multirow{11}{*}{$\left(31^{\circ} \mathrm{N}, 85^{\circ} \mathrm{E}\right)$} & *AST3A1 0303040505241507090001 & 20030304 & 30.96 & 86.24 & \multirow{11}{*}{$11(6), 0(0)$} \\
\hline & AST3A1 0303040505331507090001 & 20030304 & 30.43 & 86.10 & \\
\hline & AST3A1 0303040505421205010024 & 20030304 & 29.90 & 85.96 & \\
\hline & *AST3A1 0711010510411206180010 & 20071101 & 30.86 & 85.40 & \\
\hline & *AST3A1 0711010510491204260040 & 20071101 & 30.33 & 85.26 & \\
\hline & *AST3A1 0711010510581204260045 & 20071101 & 29.80 & 85.12 & \\
\hline & AST3A1 0403130511301206150029 & 20040313 & 30.33 & 85.21 & \\
\hline & AST3A1 0803010504551507090001 & 20080301 & 30.48 & 85.75 & \\
\hline & AST3A1 0803010505031204260054 & 20080301 & 29.95 & 85.59 & \\
\hline & *AST3A1 1111280510241502060001 & 20111128 & 30.79 & 85.82 & \\
\hline & *AST3A1 0801040511041507130001 & 20080104 & 30.92 & 85.01 & \\
\hline \multirow{10}{*}{$\left(31^{\circ} \mathrm{N}, 86^{\circ} \mathrm{E}\right)$} & AST3A1 0409230457551502060001 & 20040923 & 31.07 & 87.02 & \multirow{10}{*}{$10(4), 0(0)$} \\
\hline & AST3A1 0409230458041504140001 & 20040923 & 30.54 & 86.88 & \\
\hline & *AST3A1 0202220500171502060001 & 20020222 & 31.13 & 86.59 & \\
\hline & AST3A1 0202220500261504140001 & 20020222 & 30.60 & 86.46 & \\
\hline & AST3A1 0202220500351204260041 & 20020222 & 30.07 & 86.32 & \\
\hline & *AST3A1 0303040505241507090001 & 20030304 & 30.96 & 86.24 & \\
\hline & *AST3A1 0303040505331507090001 & 20030304 & 30.43 & 86.10 & \\
\hline & *AST3A1 0303040505421205010024 & 20030304 & 29.90 & 85.96 & \\
\hline & AST3A1 0011150512141205020002 & 20001115 & 30.02 & 86.69 & \\
\hline & AST3A1 0210040500021507080001 & 20021004 & 29.96 & 87.10 & \\
\hline
\end{tabular}


Table A1. Cont.

\begin{tabular}{|c|c|c|c|c|c|}
\hline $\begin{array}{l}\quad \mathbf{1}^{\circ} \times \mathbf{1}^{\circ} \text { Tile's }^{\prime} \\
\text { South-Western Corner } \\
\text { (Latitude, Longitude) }\end{array}$ & $\begin{array}{l}\text { JSS Granule ID }{ }^{1,2} \text { of ASTER Product Used for } \\
\text { Mapping, Listed in the Order of Priority }\end{array}$ & $\begin{array}{l}\text { Observation Date } \\
\text { (yyyymmdd) }\end{array}$ & $\begin{array}{l}\text { Latitude at the } \\
\text { Scene Center }\left({ }^{\circ} \mathrm{N}\right)\end{array}$ & $\begin{array}{l}\text { Longitude at the } \\
\text { Scene Center }\left({ }^{\circ} \mathrm{E}\right)\end{array}$ & $\begin{array}{l}\text { Number of Products } \\
\text { (Number Redundant) } \\
\text { for Level-3A, Level-1B }\end{array}$ \\
\hline \multirow{10}{*}{$\left(31^{\circ} \mathrm{N}, 87^{\circ} \mathrm{E}\right)$} & *AST3A1 0110100458081507080001 & 20011010 & 31.14 & 88.07 & \multirow{10}{*}{$10(5), 0(0)$} \\
\hline & AST3A1 0110100458171507080001 & 20011010 & 30.61 & 87.94 & \\
\hline & AST3A1 0110100458261205080027 & 20011010 & 30.08 & 87.80 & \\
\hline & AST3A1 0010300512111507080001 & 20001030 & 30.44 & 87.59 & \\
\hline & AST3A1 0010300512201205080019 & 20001030 & 29.91 & 87.45 & \\
\hline & *AST3A1 0409230457551502060001 & 20040923 & 31.07 & 87.02 & \\
\hline & *AST3A1 0210040459451507080001 & 20021004 & 31.02 & 87.37 & \\
\hline & AST3A1 0210040459531507080001 & 20021004 & 30.49 & 87.23 & \\
\hline & *AST3A1 0210040500021507080001 & 20021004 & 29.96 & 87.10 & \\
\hline & *AST3A1 0010300512021507200001 & 20001030 & 30.97 & 87.73 & \\
\hline \multirow{12}{*}{$\left(31^{\circ} \mathrm{N}, 88^{\circ} \mathrm{E}\right)$} & AST3A1 0112130455491507080001 & 20011213 & 30.98 & 89.24 & \multirow{12}{*}{$12(4), 0(0)$} \\
\hline & AST3A1 0112130455581507080001 & 20011213 & 30.44 & 89.10 & \\
\hline & AST3A1 0112130456071205090002 & 20011213 & 29.91 & 88.96 & \\
\hline & AST3A1 0910160452251507080001 & 20091016 & 31.07 & 88.58 & \\
\hline & AST3A1 0910160452341507080001 & 20091016 & 30.54 & 88.44 & \\
\hline & AST3A1 0910160452431205080040 & 20091016 & 30.01 & 88.30 & \\
\hline & *AST3A1 0110100458081507080001 & 20011010 & 31.14 & 88.07 & \\
\hline & *AST3A1 0110100458171507080001 & 20011010 & 30.61 & 87.94 & \\
\hline & *AST3A1 0110100458261507080001 & 20011010 & 30.08 & 87.80 & \\
\hline & *AST3A1 0201050501231507080001 & 20020105 & 30.81 & 88.80 & \\
\hline & AST3A1 0201050501321205090002 & 20020105 & 30.28 & 88.66 & \\
\hline & AST3A1 0201050501410303021091 & 20020105 & 29.75 & 88.51 & \\
\hline \multirow{9}{*}{$\left(31^{\circ} \mathrm{N}, 89^{\circ} \mathrm{E}\right)$} & *AST3A1 0112130455491507080001 & 20011213 & 30.98 & 89.24 & \multirow{9}{*}{$9(5), 0(0)$} \\
\hline & *AST3A1 0112130455581507080001 & 20011213 & 30.44 & 89.10 & \\
\hline & *AST3A1 0112130456071205090002 & 20011213 & 29.91 & 88.96 & \\
\hline & *AST3A1 0202150453591507080001 & 20020215 & 30.91 & 89.67 & \\
\hline & AST3A1 0202150454081507080001 & 20020215 & 30.38 & 89.53 & \\
\hline & AST3A1 0202150454171205110016 & 20020215 & 29.85 & 89.39 & \\
\hline & *AST3A1 0403010446481507080001 & 20040301 & 31.08 & 90.04 & \\
\hline & AST3A1 0403010446571507080001 & 20040301 & 30.55 & 89.90 & \\
\hline & AST3A1 0403010447061205110002 & 20040301 & 30.02 & 89.77 & \\
\hline
\end{tabular}


Table A1. Cont.

\begin{tabular}{|c|c|c|c|c|c|}
\hline $\begin{array}{l}\quad \mathbf{1}^{\circ} \times \mathbf{1}^{\circ} \text { Tile's }^{\prime} \\
\text { South-Western Corner } \\
\text { (Latitude, Longitude) }\end{array}$ & $\begin{array}{l}\text { JSS Granule ID }{ }^{1,2} \text { of ASTER Product Used for } \\
\text { Mapping, Listed in the Order of Priority }\end{array}$ & $\begin{array}{l}\text { Observation Date } \\
\text { (yyyymmdd) }\end{array}$ & $\begin{array}{l}\text { Latitude at the } \\
\text { Scene Center }\left({ }^{\circ} \mathrm{N}\right)\end{array}$ & $\begin{array}{l}\text { Longitude at the } \\
\text { Scene Center }\left({ }^{\circ} \mathrm{E}\right)\end{array}$ & $\begin{array}{l}\text { Number of Products } \\
\text { (Number Redundant) } \\
\text { for Level-3A, Level-1B }\end{array}$ \\
\hline \multirow{11}{*}{$\left(30^{\circ} \mathrm{N}, 84^{\circ} \mathrm{E}\right)$} & AST3A1 0011290524081206050064 & 20001129 & 29.91 & 84.38 & \multirow{11}{*}{$11(2), 0(0)$} \\
\hline & AST3A1 0210020512371004140508 & 20021002 & 29.38 & 84.21 & \\
\hline & *AST3A1 0011040530460907220504 & 20001104 & 29.74 & 83.91 & \\
\hline & AST3A1 0411170503471206050025 & 20041117 & 30.00 & 85.22 & \\
\hline & *AST3A1 0411170503561206050032 & 20041117 & 29.47 & 85.09 & \\
\hline & AST3A1 0701170511191004160020 & 20070117 & 29.86 & 84.71 & \\
\hline & AST3A1 0701170511281004160021 & 20070117 & 29.32 & 84.57 & \\
\hline & AST3A1 0410230510301206050004 & 20041023 & 28.75 & 84.74 & \\
\hline & AST3A1 0411010504151206050005 & 20041101 & 28.95 & 84.87 & \\
\hline & AST3A1 0310050511251004140516 & 20031005 & 28.84 & 84.12 & \\
\hline & AST3A1 1110110511041204270015 & 20111011 & 28.78 & 84.49 & \\
\hline \multirow{8}{*}{$\left(30^{\circ} \mathrm{N}, 85^{\circ} \mathrm{E}\right)$} & *AST3A1 0411170503561206050032 & 20041117 & 29.47 & 85.09 & \multirow{8}{*}{$8(2), 0(0)$} \\
\hline & *AST3A1 0411170503471206050025 & 20041117 & 30.00 & 85.22 & \\
\hline & AST3A1 0010280524570907220501 & 20001028 & 29.22 & 85.29 & \\
\hline & AST3A1 0310300505021204260003 & 20031030 & 29.90 & 85.95 & \\
\hline & AST3A1 0310300505111204260004 & 20031030 & 29.37 & 85.81 & \\
\hline & AST3A1 0310300505201204200035 & 20031030 & 28.84 & 85.67 & \\
\hline & AST3A1 0202040513121204260038 & 20020204 & 30.28 & 85.54 & \\
\hline & AST3A1 0010280524481206050027 & 20001028 & 29.75 & 85.43 & \\
\hline \multirow{12}{*}{$\left(30^{\circ} \mathrm{N}, 86^{\circ} \mathrm{E}\right)$} & *AST3A1 0310300505201204200035 & 20031030 & 28.84 & 85.67 & \multirow{12}{*}{$12(4), 0(0)$} \\
\hline & *AST3A1 0310300505111204260004 & 20031030 & 29.37 & 85.81 & \\
\hline & *AST3A1 0310300505021204260003 & 20031030 & 29.90 & 85.95 & \\
\hline & AST3A1 0411100458011204200007 & 20041110 & 28.87 & 86.99 & \\
\hline & AST3A1 0411100457521205020002 & 20041110 & 29.40 & 87.12 & \\
\hline & AST3A1 0411100457431205020002 & 20041110 & 29.93 & 87.26 & \\
\hline & *AST3A1 0011150512141205020002 & 20001115 & 30.02 & 86.69 & \\
\hline & AST3A1 0011150512231205020003 & 20001115 & 28.95 & 86.42 & \\
\hline & AST3A1 0011150512321204200002 & 20001115 & 29.48 & 86.55 & \\
\hline & AST3A1 0405020458581204260004 & 20040502 & 30.06 & 86.37 & \\
\hline & AST3A1 0405020459071204260003 & 20040502 & 29.53 & 86.23 & \\
\hline & AST3A1 0405020459161204200032 & 20040502 & 29.00 & 86.10 & \\
\hline
\end{tabular}


Table A1. Cont.

\begin{tabular}{|c|c|c|c|c|c|}
\hline $\begin{array}{l}\mathbf{1}^{\circ} \times \mathbf{1}^{\circ} \text { Tile's }^{\prime} \\
\text { South-Western Corner } \\
\text { (Latitude, Longitude) }\end{array}$ & $\begin{array}{l}\text { JSS Granule ID }{ }^{1,2} \text { of ASTER Product Used for } \\
\text { Mapping, Listed in the Order of Priority }\end{array}$ & $\begin{array}{l}\text { Observation Date } \\
\text { (yyyymmdd) }\end{array}$ & $\begin{array}{c}\text { Latitude at the } \\
\text { Scene Center }\left({ }^{\circ} \mathrm{N}\right)\end{array}$ & $\begin{array}{l}\text { Longitude at the } \\
\text { Scene Center }\left({ }^{\circ} \mathrm{E}\right)\end{array}$ & $\begin{array}{l}\text { Number of Products } \\
\text { (Number Redundant) } \\
\text { for Level-3A, Level-1B }\end{array}$ \\
\hline \multirow{12}{*}{$\left(30^{\circ} \mathrm{N}, 87^{\circ} \mathrm{E}\right)$} & *AST3A1 0411100457521205020002 & 20041110 & 29.40 & 87.12 & \multirow{12}{*}{$12(4), 0(0)$} \\
\hline & *AST3A1 0411100457431205020002 & 20041110 & 29.93 & 87.26 & \\
\hline & AST3A1 0310230459111204200011 & 20031023 & 28.84 & 87.21 & \\
\hline & AST3A1 0310230459021205020008 & 20031023 & 29.37 & 87.34 & \\
\hline & *AST3A1 0010300512201205080019 & 20001030 & 29.91 & 87.45 & \\
\hline & AST3A1 0711030458521205080020 & 20071103 & 28.73 & 87.94 & \\
\hline & AST3A1 0711030458431205080021 & 20071103 & 29.26 & 88.08 & \\
\hline & AST3A1 0711030458341205080025 & 20071103 & 29.79 & 88.22 & \\
\hline & *AST3A1 0110100458261205080027 & 20011010 & 30.08 & 87.80 & \\
\hline & AST3A1 0911080459051205080026 & 20091108 & 29.85 & 87.81 & \\
\hline & AST3A1 0911080459131205080023 & 20091108 & 29.32 & 87.67 & \\
\hline & AST3A1 0911080459221205080022 & 20091108 & 28.79 & 87.53 & \\
\hline \multirow{11}{*}{$\left(30^{\circ} \mathrm{N}, 88^{\circ} \mathrm{E}\right)$} & AST3A1 0111270457121507270001 & 20011127 & 28.86 & 88.62 & \multirow{11}{*}{$11(3), 0(0)$} \\
\hline & AST3A1 0111270457031507270001 & 20011127 & 29.39 & 88.76 & \\
\hline & AST3A1 0111270456541205090002 & 20011127 & 29.92 & 88.90 & \\
\hline & AST3A1 0210290454101507270001 & 20021029 & 28.90 & 88.35 & \\
\hline & AST3A1 0210290454011507270001 & 20021029 & 29.43 & 88.48 & \\
\hline & AST3A1 0012010511391507270001 & 20001201 & 29.74 & 88.58 & \\
\hline & AST3A1 0111110457261507270001 & 20011111 & 28.95 & 87.98 & \\
\hline & *AST3A1 0110100458261205080027 & 20011010 & 30.08 & 87.80 & \\
\hline & *AST3A1 0711030458431205080021 & 20071103 & 29.26 & 88.08 & \\
\hline & *AST3A1 0711030458341205080025 & 20071103 & 29.79 & 88.22 & \\
\hline & AST3A1 0011010500081507270001 & 20001101 & 28.99 & 89.21 & \\
\hline \multirow{10}{*}{$\left(30^{\circ} \mathrm{N}, 89^{\circ} \mathrm{E}\right)$} & *AST3A1 0011010500081507270001 & 20001101 & 28.99 & 89.21 & \multirow{10}{*}{$10(3), 0(0)$} \\
\hline & AST3A1 0403010447241507270001 & 20040301 & 28.95 & 89.50 & \\
\hline & AST3A1 0512080451591205110009 & 20051208 & 29.23 & 89.81 & \\
\hline & AST3A1 0512240451471205110002 & 20051224 & 29.22 & 89.90 & \\
\hline & AST3A1 0512080451501205110002 & 20051208 & 29.77 & 89.95 & \\
\hline & *AST3A1 0403010447061205110002 & 20040301 & 30.02 & 89.77 & \\
\hline & AST3A1 0403010447151507270001 & 20040301 & 29.48 & 89.63 & \\
\hline & AST3A1 0311100447031507270001 & 20031110 & 29.53 & 89.28 & \\
\hline & AST3A1 0311100446541205110002 & 20031110 & 30.07 & 89.41 & \\
\hline & *AST3A1 0111270456541205090002 & 20011127 & 29.92 & 88.90 & \\
\hline
\end{tabular}


Table A1. Cont.

\begin{tabular}{|c|c|c|c|c|c|}
\hline $\begin{array}{l}1^{\circ} \times 1^{\circ} \text { Tile's } \\
\text { South-Western Corner } \\
\text { (Latitude, Longitude) }\end{array}$ & $\begin{array}{l}\text { JSS Granule ID }{ }^{1,2} \text { of ASTER Product Used for } \\
\text { Mapping, Listed in the Order of Priority }\end{array}$ & $\begin{array}{l}\text { Observation Date } \\
\text { (yyyymmdd) }\end{array}$ & $\begin{array}{l}\text { Latitude at the } \\
\text { Scene Center }\left({ }^{\circ} \mathrm{N}\right)\end{array}$ & $\begin{array}{l}\text { Longitude at the } \\
\text { Scene Center }\left({ }^{\circ} \mathrm{E}\right)\end{array}$ & $\begin{array}{l}\text { Number of Products } \\
\text { (Number Redundant) } \\
\text { for Level-3A, Level-1B }\end{array}$ \\
\hline \multirow{15}{*}{$\left(29^{\circ} \mathrm{N}, 84^{\circ} \mathrm{E}\right)$} & AST3A1 1203030511501205100017 & 20120303 & 27.68 & 84.50 & \multirow{15}{*}{$15(1), 0(0)$} \\
\hline & AST3A1 0010280525060907210629 & 20001028 & 28.69 & 85.14 & \\
\hline & AST3A1 0012150524111004140500 & 20001215 & 28.84 & 84.09 & \\
\hline & *AST3A1 1110110511041204270015 & 20111011 & 28.78 & 84.49 & \\
\hline & AST3A1 0410230510211205010018 & 20041023 & 29.28 & 84.88 & \\
\hline & AST3A1 0711010511161204260046 & 20071101 & 28.73 & 84.83 & \\
\hline & AST3A1 0411010504331205100009 & 20041101 & 27.89 & 84.61 & \\
\hline & AST3A1 0511040504511205100028 & 20051104 & 27.89 & 84.57 & \\
\hline & AST3A1 0311220512301205100011 & 20031122 & 28.17 & 84.88 & \\
\hline & AST3A1 0411010504241205100016 & 20041101 & 28.42 & 84.74 & \\
\hline & AST3A1 0402100512331205100014 & 20040210 & 27.79 & 83.74 & \\
\hline & AST3A1 0402100512241205100010 & 20040210 & 28.32 & 83.87 & \\
\hline & AST3A1 0804090511461205100039 & 20080409 & 27.77 & 83.91 & \\
\hline & AST3A1 0801040511481205100011 & 20080104 & 28.26 & 84.31 & \\
\hline & AST3A1 0103050523021205100025 & 20010305 & 27.73 & 84.15 & \\
\hline \multirow{11}{*}{$\left(29^{\circ} \mathrm{N}, 85^{\circ} \mathrm{E}\right)$} & *AST3A1 0010280525060907210629 & 20001028 & 28.69 & 85.14 & \multirow{11}{*}{$11(4), 0(0)$} \\
\hline & *AST3A1 0010280524570907220501 & 20001028 & 29.22 & 85.29 & \\
\hline & AST3A1 0412030504281205100021 & 20041203 & 27.87 & 84.70 & \\
\hline & AST3A1 0412280458411204200002 & 20041228 & 27.93 & 85.84 & \\
\hline & AST3A1 0412280458321204200002 & 20041228 & 28.46 & 85.97 & \\
\hline & AST3A1 0412280458231204200004 & 20041228 & 29.00 & 86.10 & \\
\hline & *AST3A1 0311220512301205100011 & 20031122 & 28.17 & 84.88 & \\
\hline & *AST3A1 0310300505201204200035 & 20031030 & 28.84 & 85.67 & \\
\hline & AST3A1 0502210504451205110076 & 20050221 & 27.76 & 85.46 & \\
\hline & AST3A1 0711170511231205100013 & 20071117 & 28.14 & 85.08 & \\
\hline & AST3A1 0310300505291205110074 & 20031030 & 28.31 & 85.54 & \\
\hline
\end{tabular}


Table A1. Cont.

\begin{tabular}{|c|c|c|c|c|c|}
\hline $\begin{array}{l}\mathbf{1}^{\circ} \times \mathbf{1}^{\circ} \text { Tile's }^{\prime} \\
\text { South-Western Corner } \\
\text { (Latitude, Longitude) }\end{array}$ & $\begin{array}{l}\text { JSS Granule ID }{ }^{1,2} \text { of ASTER Product Used for } \\
\text { Mapping, Listed in the Order of Priority }\end{array}$ & $\begin{array}{l}\text { Observation Date } \\
\text { (yyyymmdd) }\end{array}$ & $\begin{array}{l}\text { Latitude at the } \\
\text { Scene Center }\left({ }^{\circ} \mathrm{N}\right)\end{array}$ & $\begin{array}{l}\text { Longitude at the } \\
\text { Scene Center }\left({ }^{\circ} \mathrm{E}\right)\end{array}$ & $\begin{array}{l}\text { Number of Products } \\
\text { (Number Redundant) } \\
\text { for Level-3A, Level-1B }\end{array}$ \\
\hline \multirow{10}{*}{$\left(29^{\circ} \mathrm{N}, 86^{\circ} \mathrm{E}\right)$} & AST3A1 0511130458411204200002 & 20051113 & 27.79 & 86.80 & \multirow{10}{*}{$10(5), 0(0)$} \\
\hline & *AST3A1 0011150512321204200002 & 20001115 & 28.95 & 86.42 & \\
\hline & AST3A1 0011150512411204200002 & 20001115 & 28.42 & 86.29 & \\
\hline & *AST3A1 0412280458411204200002 & 20041228 & 27.93 & 85.84 & \\
\hline & *AST3A1 0412280458321204200002 & 20041228 & 28.46 & 85.97 & \\
\hline & *AST3A1 0412280458231204200004 & 20041228 & 29.00 & 86.10 & \\
\hline & AST3A1 0411100458191204200008 & 20041110 & 27.81 & 86.72 & \\
\hline & AST3A1 0411100458101204200005 & 20041110 & 28.34 & 86.85 & \\
\hline & *AST3A1 0411100458011204200007 & 20041110 & 28.87 & 86.99 & \\
\hline & AST3A1 0512060504391204200002 & 20051206 & 28.17 & 86.42 & \\
\hline \multirow{10}{*}{$\left(29^{\circ} \mathrm{N}, 87^{\circ} \mathrm{E}\right)$} & AST3A1 0310230459291204200003 & 20031023 & 27.77 & 86.93 & \multirow{10}{*}{$10(1), 0(0)$} \\
\hline & AST3A1 0112200502111204200042 & 20011220 & 28.84 & 87.21 & \\
\hline & AST3A1 0112200502201204200045 & 20011220 & 29.37 & 87.34 & \\
\hline & AST3A1 0201050501591507270001 & 20020105 & 28.69 & 88.23 & \\
\hline & AST3A1 0201050502071205140002 & 20020105 & 28.16 & 88.09 & \\
\hline & AST3A1 0011240506261205140002 & 20001124 & 27.93 & 87.36 & \\
\hline & *AST3A1 0711030458521205080020 & 20071103 & 28.73 & 87.94 & \\
\hline & AST3A1 0711030459011205140002 & 20071103 & 28.20 & 87.80 & \\
\hline & AST3A1 0712210459141205080048 & 20071221 & 28.79 & 87.54 & \\
\hline & AST3A1 0712210459221204230014 & 20071221 & 28.26 & 87.41 & \\
\hline \multirow{9}{*}{$\left(29^{\circ} \mathrm{N}, 88^{\circ} \mathrm{E}\right)$} & *AST3A1 0111270457121507270001 & 20011127 & 28.86 & 88.62 & \multirow{9}{*}{$9(4), 0(0)$} \\
\hline & AST3A1 0201050501501507270001 & 20020105 & 29.22 & 88.37 & \\
\hline & *AST3A1 0201050501591507270001 & 20020105 & 28.69 & 88.23 & \\
\hline & AST3A1 0112130456331205150009 & 20011213 & 28.32 & 88.55 & \\
\hline & AST3A1 0112130456421205140009 & 20011213 & 27.78 & 88.42 & \\
\hline & *AST3A1 0011010500081507270001 & 20001101 & 28.99 & 89.21 & \\
\hline & AST3A1 0011010500171205150010 & 20001101 & 28.46 & 89.08 & \\
\hline & AST3A1 0011010500261205150003 & 20001101 & 27.93 & 88.95 & \\
\hline & *AST3A1 0201050502071205140002 & 20020105 & 28.16 & 88.09 & \\
\hline
\end{tabular}


Table A1. Cont.

\begin{tabular}{|c|c|c|c|c|c|}
\hline $\begin{array}{l}\mathbf{1}^{\circ} \times \mathbf{1}^{\circ} \text { Tile's }^{\prime} \\
\text { South-Western Corner } \\
\text { (Latitude, Longitude) }\end{array}$ & $\begin{array}{l}\text { JSS Granule ID }{ }^{1,2} \text { of ASTER Product Used for } \\
\text { Mapping, Listed in the Order of Priority }\end{array}$ & $\begin{array}{l}\text { Observation Date } \\
\text { (yyyymmdd) }\end{array}$ & $\begin{array}{c}\text { Latitude at the } \\
\text { Scene Center }\left({ }^{\circ} \mathrm{N}\right)\end{array}$ & $\begin{array}{l}\text { Longitude at the } \\
\text { Scene Center }\left({ }^{\circ} \mathrm{E}\right)\end{array}$ & $\begin{array}{l}\text { Number of Products } \\
\text { (Number Redundant) } \\
\text { for Level-3A, Level-1B }\end{array}$ \\
\hline \multirow{14}{*}{$\left(29^{\circ} \mathrm{N}, 89^{\circ} \mathrm{E}\right)$} & AST3A1 0111200451211205150047 & 20011120 & 27.79 & 89.94 & \multirow{13}{*}{$13(6), 0(0)$} \\
\hline & *AST3A1 0512080451591205110009 & 20051208 & 29.23 & 89.81 & \\
\hline & *AST3A1 0512240451471205110002 & 20051224 & 29.22 & 89.90 & \\
\hline & AST3A1 0411030451541205110041 & 20041103 & 28.69 & 89.76 & \\
\hline & AST3A1 0111200451121205150046 & 20011120 & 28.32 & 90.07 & \\
\hline & *AST3A1 0011010500081507270001 & 20001101 & 28.99 & 89.21 & \\
\hline & *AST3A1 0011010500171205150010 & 20001101 & 28.46 & 89.08 & \\
\hline & *AST3A1 0011010500261205150003 & 20001101 & 27.93 & 88.95 & \\
\hline & AST3A1 0301100447491205150031 & 20030110 & 28.36 & 89.83 & \\
\hline & AST3A1 0301100447581205150030 & 20030110 & 27.82 & 89.70 & \\
\hline & *AST3A1 0403010447241507270001 & 20040301 & 28.95 & 89.50 & \\
\hline & AST3A1 0403010447331205150033 & 20040301 & 28.42 & 89.37 & \\
\hline & AST3A1 0403010447411205150004 & 20040301 & 27.89 & 89.24 & \\
\hline & & & & & $\begin{array}{c}\text { In total, } 380 \text { (Level-3A) } \\
6 \text { (Level-1B) products }\end{array}$ \\
\hline
\end{tabular}




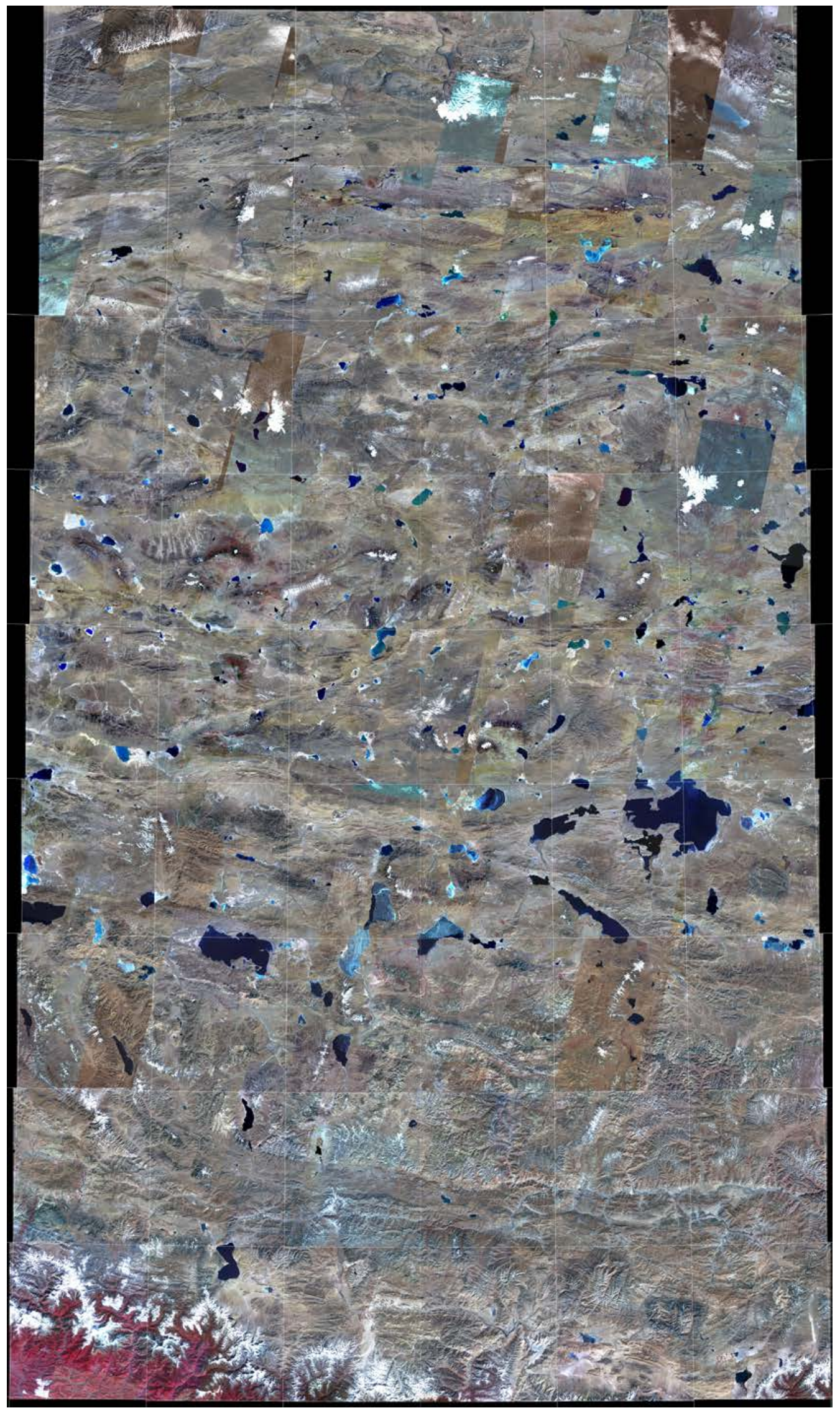

Figure A1. High resolution version of Figure 2 without annotated information. 


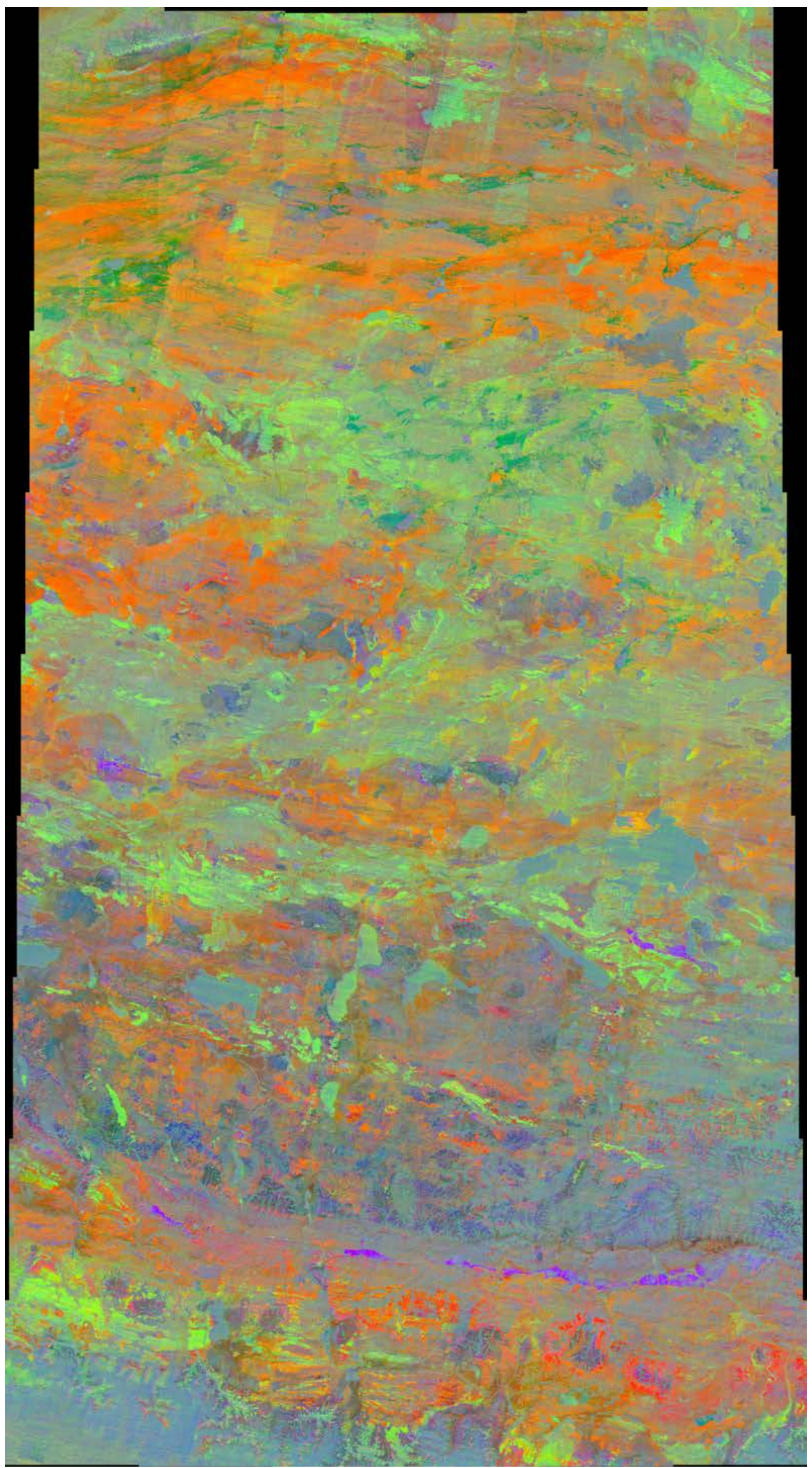

Figure A2. High resolution version of Figure 4 without annotated information. 


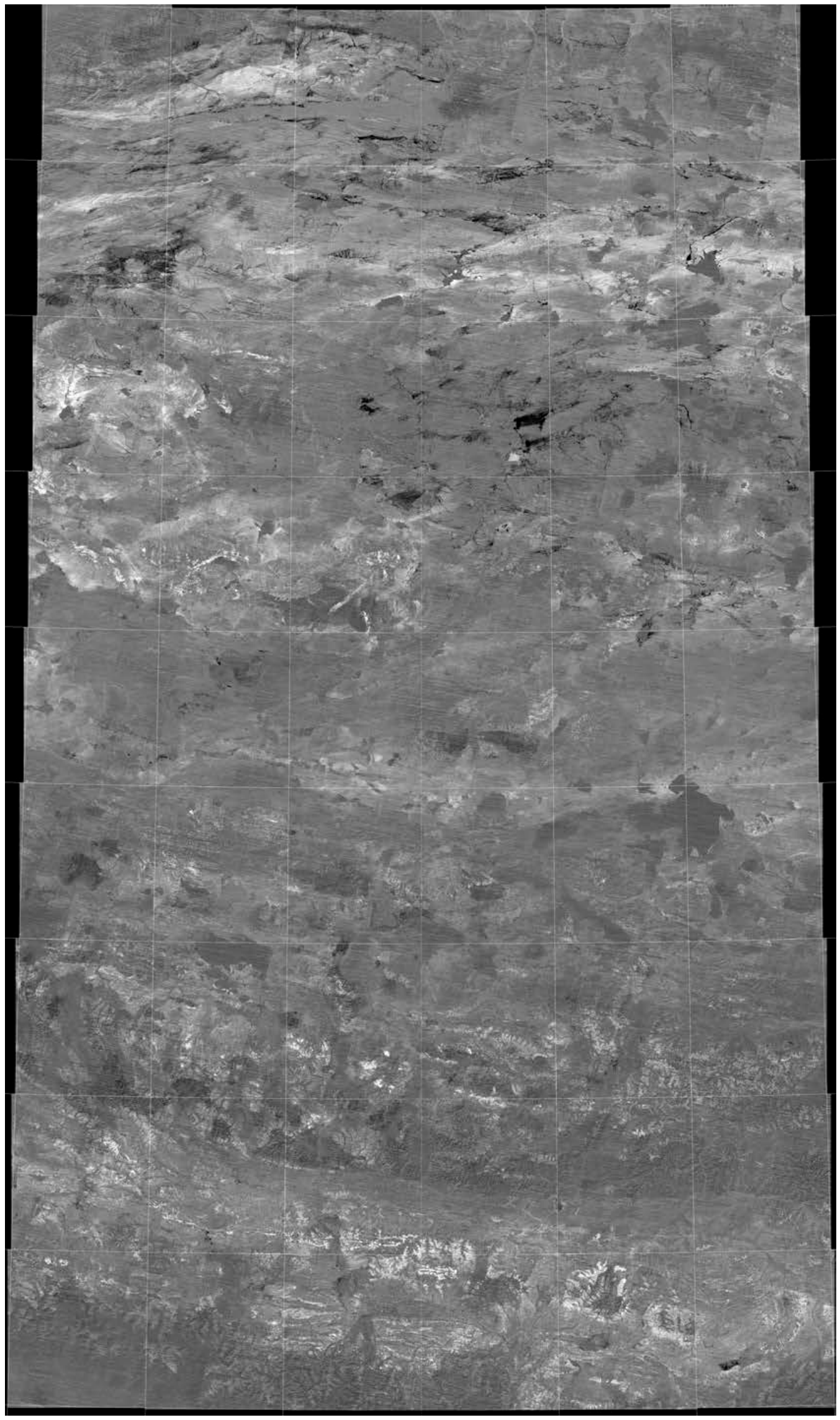

Figure A3. High resolution version of Figure 5a without annotated information. 


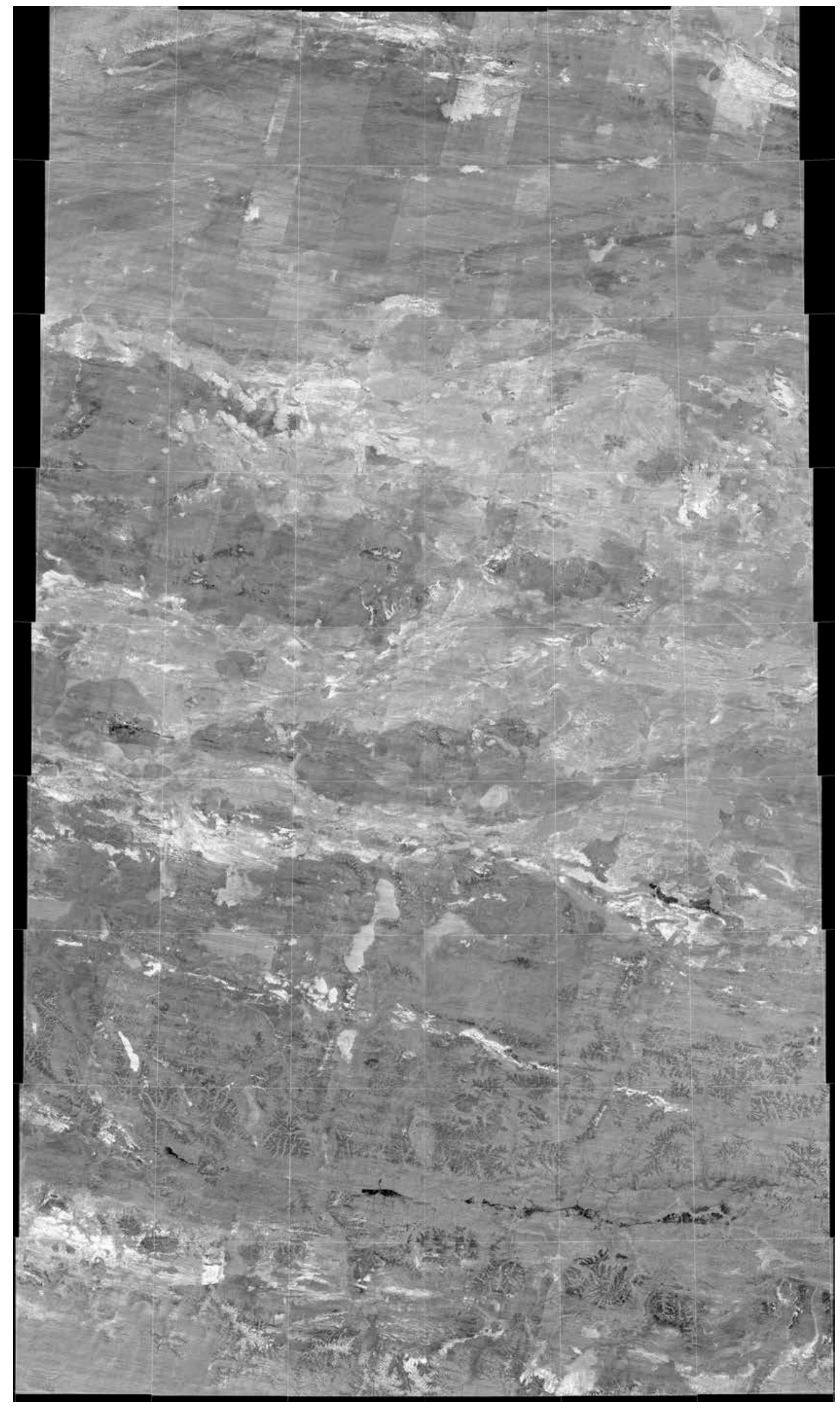

Figure A4. High resolution version of Figure $5 \mathrm{~b}$ without annotated information. 


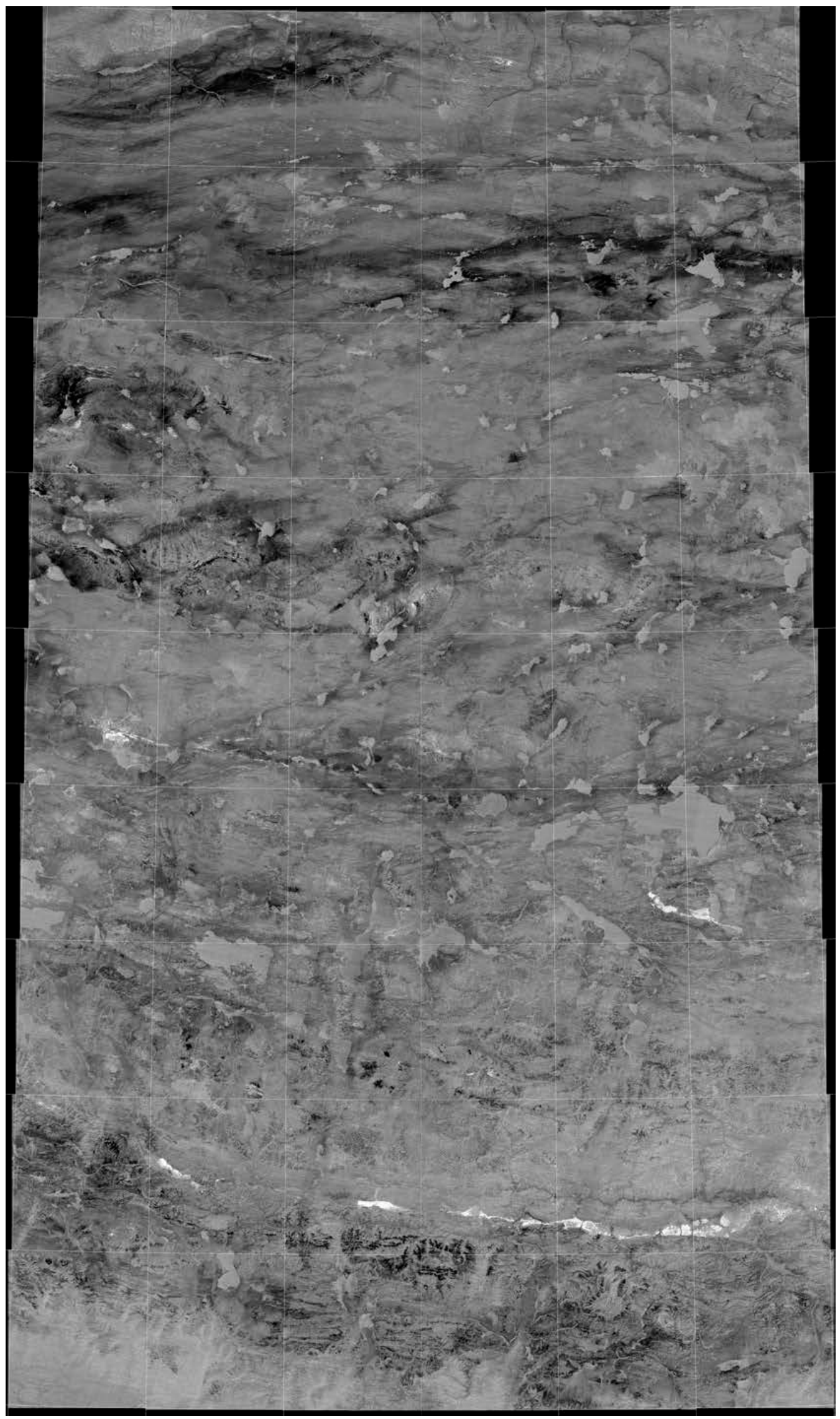

Figure A5. High resolution version of Figure $5 c$ without annotated information. 


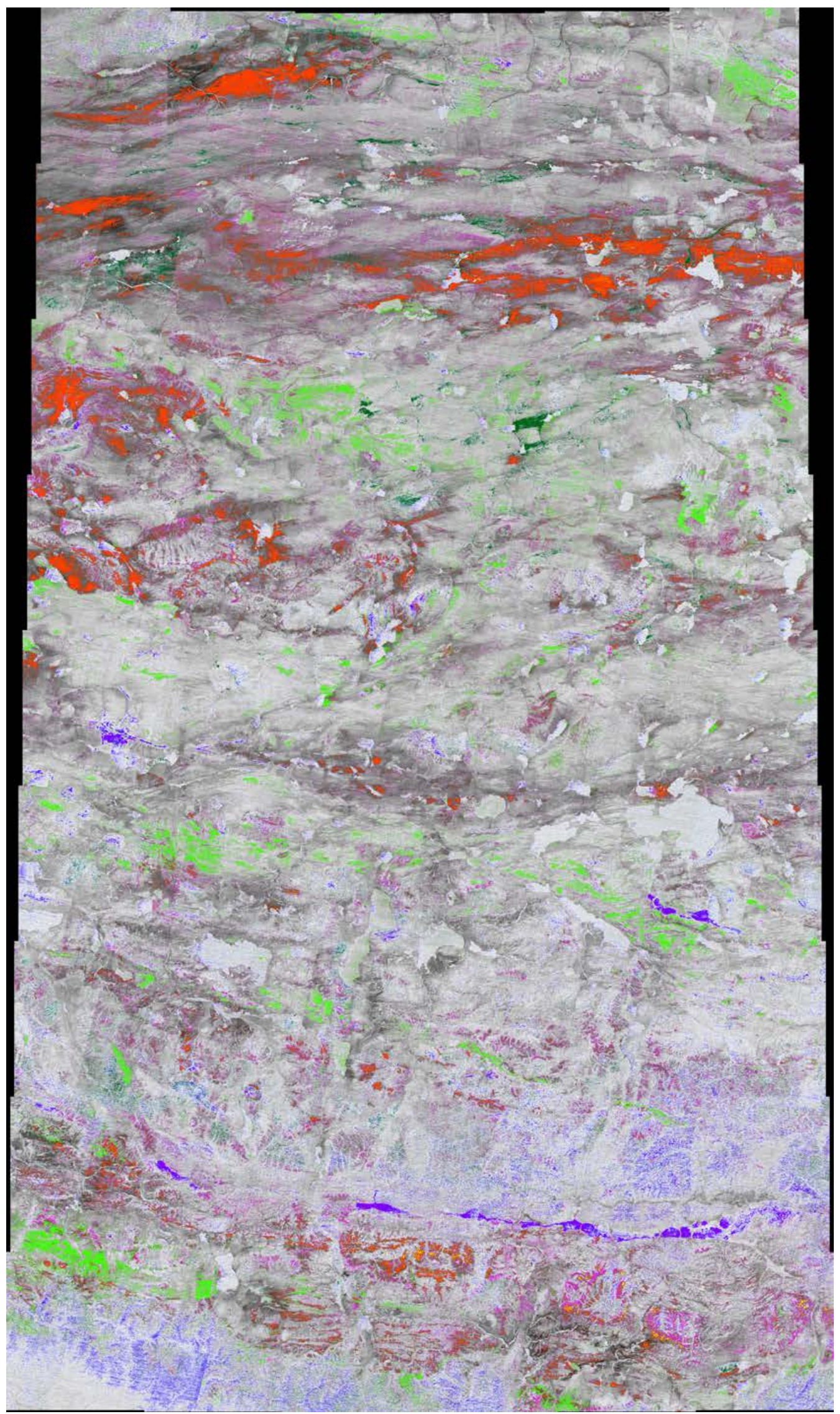

Figure A6. High resolution version of Figure 6 without annotated information. 


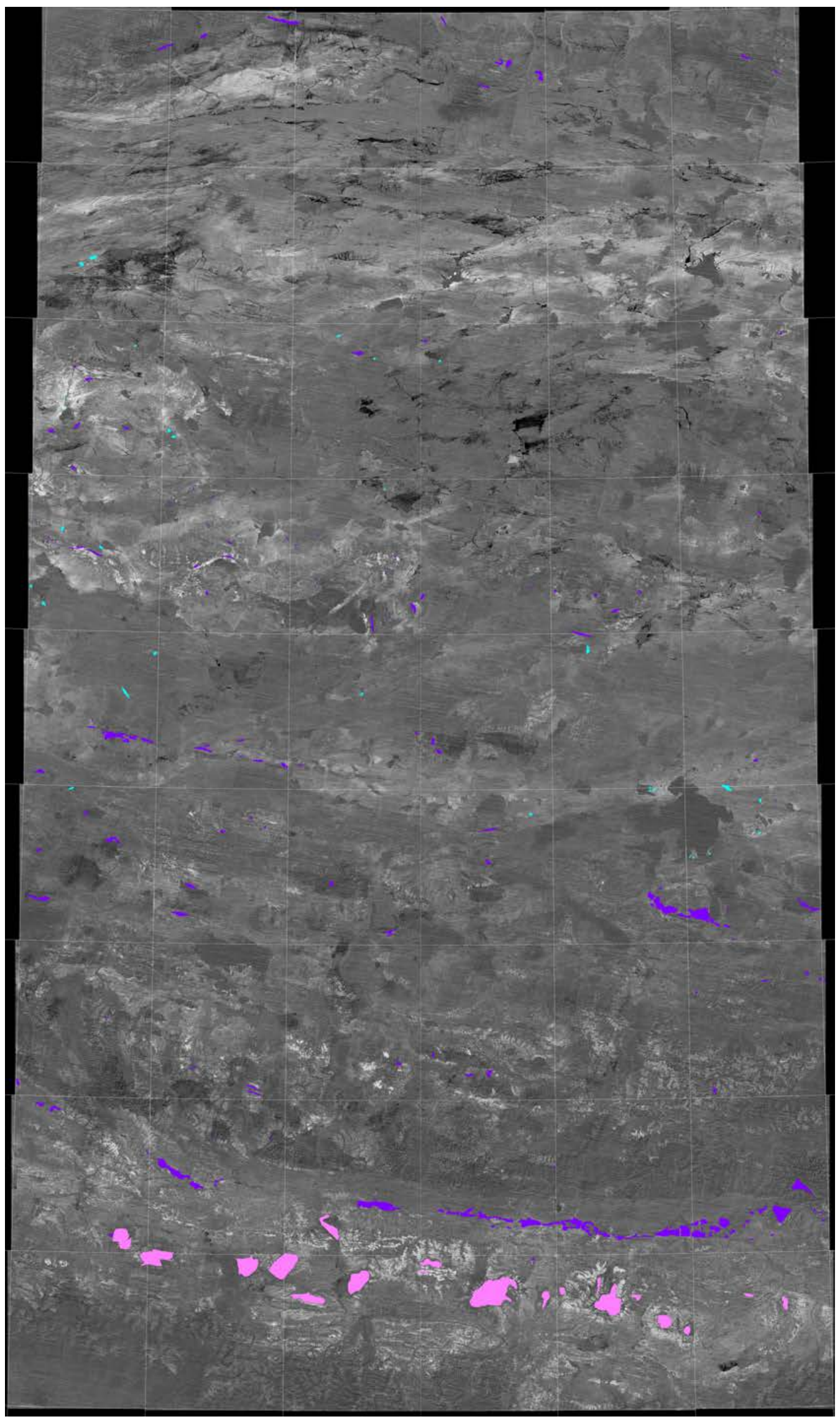

Figure A7. High resolution version of Figure 8 without annotated information. 


\section{References}

1. Hunt, J.M.; Wisherd, M.P.; Bonham, L.C. Infrared Absorption Spectra of Minerals and Other Inorganic Compounds. Anal. Chem. 1950, 22, 1478-1497.

2. Miller, F.A.; Wilkins, C.H. Infrared Spectra and Characteristic Frequencies of Inorganic Ions. Anal. Chem. 1952, 24, 1253-1294. [CrossRef]

3. Hunt, G.R. Spectral signatures of particulate minerals in visible and near infrared. Geophysics 1977, 42, 501-513. [CrossRef]

4. Logan, L.M.; Hunt, G.R.; Salisbury, J.W.; Salvatore, R.B. Compositional implications of Christiansen frequency maximums for infrared remote sensing applications. J. Geophys. Res. 1973, 78, 4983-5003. [CrossRef]

5. Stubican, V.; Roy, R. Infrared Spectra of Layer-Structure Silicates. J. Am. Ceram. Soc. 1961, 44, $625-627$. [CrossRef]

6. Lyon, R.J.P. Evaluation of Infrared Spectrophotometry for Compositional Analysis of Lunar and Planetary Soils; Final Report PSU-3943; SRI: Menlo Park, CA, USA, 1964; p. 278.

7. Vincent, R.K.; Thomson, F.J. Rock-Type Discrimination from Ratioed Infrared Scanner Images of Pisgah Crater, California. Science 1972, 175, 986-988. [CrossRef] [PubMed]

8. Prabhakara, C.; Dalu, G. Remote sensing of the surface emissivity at $9 \mu$ m over the globe. J. Geophys. Res. 1976, 81, 3719-3724. [CrossRef]

9. Kahle, A.B.; Rowan, L.C. Evaluation of multispectral middle infrared aircraft images for lithologic mapping in the East Tintic Mountains, Utah. Geology 1980, 8, 234-239. [CrossRef]

10. Kahle, A.B. Surface emittance, temperature, and thermal inertia derived from Thermal Infrared Multispectral Scanner (TIMS) data for Death Valley, California. Geophysics 1987, 52, 858-874. [CrossRef]

11. Fu, B.; Chou, X. Thermal infrared spectra and TIMS imagery features of sedimentary rocks in the Kalpin Uplift, Tarim Basin, China. Geocarto Int. 1998, 13, 69-73.

12. Yamaguchi, Y.; Kahle, A.B.; Tsu, H.; Kawakami, T.; Pniel, M. Overview of Advanced Spaceborne Thermal Emission and Reflection Radiometer (ASTER). IEEE Trans. Geosci. Remote Sens. 1998, 36, 1062-1071. [CrossRef]

13. Ninomiya, Y.; Fu, B. Quartz index, carbonate index and $\mathrm{SiO}_{2}$ content index defined for ASTER TIR data. J. Remote Sens. Soc. Jpn. 2002, 22, 50-61.

14. Ninomiya, Y. Mapping quartz, carbonate minerals and mafic-ultramafic rocks using remotely sensed multispectral thermal infrared ASTER data. Proc. SPIE 2002, 4710, 191-202.

15. Ninomiya, Y. Rock type mapping with indices defined for multispectral thermal infrared ASTER data: Case studies. Proc. SPIE 2003, 4886, 123-132.

16. Ninomiya, Y. Lithologic mapping with multispectral ASTER TIR and SWIR data. Proc. SPIE 2004, 5234, 180-190.

17. Ninomiya, Y.; Fu, B.; Cudahy, T.J. Detecting lithology with Advanced Spaceborne Thermal Emission and Reflection Radiometer (ASTER) multispectral thermal infrared "radiance-at-sensor" data. Remote Sens. Environ. 2005, 99, 127-139. [CrossRef]

18. Corrie, R.K.; Ninomiya, Y.; Aitchison, J.C. Applying Advanced Spaceborne Thermal Emission and Reflection Radiometer (ASTER) spectral indices for geological mapping and mineral identification on the Tibetan Plateau. Int. Arch. Photogramm. Remote Sens. Spat. Inf. Sci. 2010, XXXVIII, 464-469.

19. Aboelkhair, H.; Ninomiya, Y.; Watanabe, Y.; Sato, I. Processing and interpretation of ASTER TIR data for mapping of rare-metal-enriched albite granitoids in the Central Eastern Desert of Egypt. J. Afr. Earth Sci. 2010, 58, 141-151. [CrossRef]

20. Khan, S.D.; Mahmood, K. The application of remote sensing techniques to the study of ophiolites. Earth-Sci. Rev. 2008, 89, 135-143. [CrossRef]

21. Mitsuishi, M.; Wallis, S.R.; Aoya, M.; Lee, J.; Wang, Y. E-W extension at 19 Ma in the Kung Co area, S. Tibet: Evidence for contemporaneous E-W and N-S extension in the Himalayan orogen. Earth Planet. Sci. Lett. 2012, 325-326, 10-20. [CrossRef]

22. Guha, A.; Kumar, V. New ASTER derived thermal indices to delineate mineralogy of different granitoids of an Archaean Craton and analysis of their potentials with reference to Ninomiya's indices for delineating quartz and mafic minerals of granitoids-An analysis in Dharwar Craton, India. Ore Geol. Rev. 2016, 74, 76-87. 
23. Tommaso, I.D.; Rubinstein, N. Hydrothermal alteration mapping using ASTER data in the Infiernillo porphyry deposit, Argentina. Ore Geol. Rev. 2007, 32, 275-290. [CrossRef]

24. Rockwell, B.W.; Hofstra, A.H. Identification of quartz and carbonate minerals across northern Nevada using ASTER thermal infrared emissivity data-Implications for geologic mapping and mineral resource investigations in well-studied and frontier areas. Geosphere 2008, 4, 218-246. [CrossRef]

25. Rajendran, S.; Hersi, O.S.; Al-Harthy, A.; Al-Wardi, M.; El-Ghali, M.A.; Al-Abri, A.H. Capability of advanced spaceborne thermal emission and reflection radiometer (ASTER) on discrimination of carbonates and associated rocks and mineral identification of eastern mountain region (Saih Hatat window) of Sultanate of Oman. Carbonates Evaporites 2011, 26, 351-364. [CrossRef]

26. Ding, C.; Liu, X.; Liu, W.; Liu, M.; Li, Y. Mafic-ultramafic and quartz-rich rock indices deduced from ASTER thermal infrared data using a linear approximation to the Planck function. Ore Geol. Rev. 2014, 60, 161-173. [CrossRef]

27. Pournamdari, M.; Hashim, M. Detection of chromite bearing mineralized zones in Abdasht ophiolite complex using ASTER and $\mathrm{ETM}^{+}$remote sensing data. Arab. J. Geosci. 2014, 7, 1973-1983. [CrossRef]

28. Emam, A.; Zoheir, B.; Johnson, P. ASTER-based mapping of ophiolitic rocks: examples from the Allaqi-Heiani suture, SE Egypt. Int. Geol. Rev. 2016, 58, 525-539. [CrossRef]

29. Rajendran, S. Mapping of Neoproterozoic source rocks of the Huqf Supergroup in the Sultanate of Oman using remote sensing. Ore Geol. Rev. 2016, 78, 281-299. [CrossRef]

30. Ninomiya, Y.; Fu, B. Regional scale lithologic mapping in western Tibet using ASTER thermal infrared multispectral data. Int. Arch. Photogram. Remote Sens. Spat. Inf. Sci. 2010, XXXVIII, 454-458.

31. Molnar, P.; Tapponnier, P. Cenozoic Tectonics of Asia. Science 1975, 189, 419-426. [CrossRef] [PubMed]

32. Dewey, J.F.; Shackleton, R.M.; Chengfa, C.; Yiyin, S. Cenozoic Tectonics of Asia. Philo. Trans. R. Soc. Lond. A 1988, 327, 379-413. [CrossRef]

33. Fu, B.; Walker, R.; Sandiford, M. The 2008 Wenchuan earthquake and active tectonics of Asia. J. Asian Earth Sci. 2011, 40, 797-805. [CrossRef]

34. Pan, G.; Wang, G.; Li, R.; Yuan, S.; Ji, W.; Yin, F.; Zhan, W. Tectonic evolution of the Qinghai-Tibet Plateau. J. Asian Earth Sci. 2012, 54, 3-14. [CrossRef]

35. Xu, Z.; Dilek, Y.; Cao, H.; Yang, J.; Robinson, P.; Ma, C.; Li, H.; Jolivetf, M.; Rogerg, F.; Chena, X. Paleo-Tethyan evolution of Tibet as recorded in the East Cimmerides and West Cathaysides. J. Asian Earth Sci. 2015, 105, 320-334. [CrossRef]

36. Burchfiel, B.C.; Chen, Z.; Hodges, K.V.; Liu, Y.; Royden, L.H.; Deng, C.; Xu, J. The South Tibetan Detachment System, Himalayan Orogen: Extension contemporaneous with and parallel to shortening in a collisional mountain belt. Geol. Soc. Am. Spec. Papers 1992, 269, 1-41.

37. Aoya, M.; Wallis, S.R.; Terada, K.; Lee, J.; Kawakami, T.; Wang, Y.; Heizler, M. North-south extension in the Tibetan crust triggered by granite emplacement. Geology 2005, 33, 853-856. [CrossRef]

38. Burg, J.P.; Guiraud, M.; Chen, G.M.; Li, G.C. Himalayan metamorphism and deformations in the North Himalayan Belt (Southern Tibet, China). Earth Planet. Sci. Lett. 1984, 69, 391-400. [CrossRef]

39. Girardeau, J.; Marcoux, J.; Foucade, E.; Bassoullet, J.P.; Tang, Y. Xainxa ultramafic rocks, central Tibet, China: Tectonic environment and geodynamic significance. Geology 1985, 13, 330-333. [CrossRef]

40. Qu, W.G.; Wang, Y.S.; Zhang, S.Q.; Wang, Z.H.; Lu, P.; Duan, J.X. New results and major progress in regional geological survey of the Toiba district sheet (1:250,000). Geol. Bull. China 2004, 23, 492-497.

41. Wang, W.L.; Aitchison, J.C.; Lo, C.H.; Zeng, Q.G. Geochemistry and geochronology of the amphibolite blocks in ophiolitic mélanges along Bangong-Nujiang suture, central Tibet. J. Asian Earth Sci. 2008, 33, 122-138. [CrossRef]

42. Baxter, A.T.; Aitchison, J.C.; Zyabrev, S.V. Radiolarian age constraints on Mesotethyan ocean evolution, and their implications for development of the Bangong-Nujiang suture, Tibet. J. Geol. Soc. 2009, 166, 689-694. [CrossRef]

43. Zhai, Q.; Jahn, B.; Wang, J.; Su, L.; Mo, X.; Wang, K.; Tang, S.; Lee, H. The Carboniferous ophiolite in the middle of the Qiangtang terrane, Northern Tibet: SHRIMP U-Pb dating, geochemical and Sr-Nd-Hf isotopic characteristics. Lithos 2013, 168-169, 186-199. [CrossRef]

44. Chengdu Institute of Geology and Mineral Resources, Chinese Academy of Geological Sciences. Geological Map of Qinghai-Tibetan Plateau; Geological Publishing House: Beijing, China, 1988. 
45. Wang, X.; Xiao, X.; Cao, Y.; Zheng, H. Geological Map of the Ophiolite Zone along the Middle Yarlung Zangbo (Tsangpo) River, Xizang (Tibet); Publishing House of Surveying and Mapping: Beijing, China, 1984.

46. ASTER Global Digital Elevation Model (GDEM). Available online: http://www.jspacesystems.or.jp/ersdac/ GDEM/E/index.html (accessed on 30 April 2016).

47. NASA. Japan Make ASTER Earth Data Available at No Cost. Available online: http://www.nasa.gov/ feature/jpl/nasa-japan-make-aster-earth-data-available-at-no-cost (accessed on 30 April 2016).

48. Earth Remote Sensing Data Analysis Center. ASTER Reference Guide, Version 1.0; 2003, p. 47. Available online: https://unit.aist.go.jp/igg/rs-rg/ASTERSciWeb_AIST/en/documnts/refernce.html (accessed on 30 April 2016).

49. Earth Remote Sensing Data Analysis Center. ASTER User's Guide Part I General, Version 4.0; 2005, p. 100. Available online: https://unit.aist.go.jp/igg/rs-rg/ASTERSciWeb_AIST/en/documnts/users_guide/index. html (accessed on 30 April 2016).

50. Earth Remote Sensing Data Analysis Center. ASTER User's Guide Part II Level 1 Data Products, Version 5.1; 2007, p. 66. Available online: https://unit.aist.go.jp/igg/rs-rg/ASTERSciWeb_AIST/en/documnts/users_ guide/index.html (accessed on 30 April 2016).

51. Level-1 Data Working Group, ASTER Science Team, Japan. Algorithm Theoretical Basis Document for ASTER Level-1 Data Processing, Version 3.0; 1996, p. 117. Available online: https://unit.aist.go.jp/igg/rs-rg/ ASTERSciWeb_AIST/en/documnts/atbd.html (accessed on 30 April 2016).

52. Thome, K.; Biggar, S.; Takashima, T. Algorithm Theoretical Basis Document for ASTER Level 2B1—Surface Radiance and ASTER Level 2B5—Surface Reflectance. 1999, p. 45. Available online: https:/ / unit.aist.go.jp/ igg/rs-rg/ASTERSciWeb_AIST/en/documnts/atbd.html (accessed on 30 April 2016).

53. Palluconi, F.; Hoover, G.; Alley, R.; Jentoft-Nilsen, M.; Thompson, T. An Atmospheric Correction Method for ASTER Thermal Radiometry over Land, Revision 3; 1999, p. 27. Available online: https:/ / unit.aist.go.jp/igg/rsrg/ASTERSciWeb_AIST/en/documnts/atbd.html (accessed on 30 April 2016).

54. Gillespie, A.R.; Rokugawa, S.; Hook, S.J.; Matsunaga, T.; Kahle, A.B. Temperature/Emissivity Separation Algorithm Theoretical Basis Document, Version 2.4; 1999, p. 64. Available online: https://unit.aist.go.jp/igg/rsrg/ASTERSciWeb_AIST/en/documnts/atbd.html (accessed on 30 April 2016).

55. Earth Remote Sensing Data Analysis Center. ASTER User's Guide Part III DEM Product (L4A01); Version 1.1; 2005, p. 19. Available online: https://unit.aist.go.jp/igg/rs-rg/ASTERSciWeb_AIST/en/documnts/users_ guide/index.html (accessed on 30 April 2016).

56. Earth Remote Sensing Data Analysis Center. ASTER User's Guide Part III 3D Ortho Product (L3A01), Version 1.1, 2004, p. 18. Available online: https://unit.aist.go.jp/igg/rs-rg/ASTERSciWeb_AIST/en/documnts/users_ guide/index.html (accessed on 30 April 2016).

57. METI AIST Data Archive System (MADAS). Available online: https://gbank.gsj.jp/madas/?lang=en\#top (accessed on 30 April 2016).

58. ASTER Overview. Land Processes Distributed Active Archive center (LP DAAC), USGS. Available online: https://lpdaac.usgs.gov/dataset_discovery/aster (accessed on 30 April 2016).

(C) 2016 by the authors; licensee MDPI, Basel, Switzerland. This article is an open access article distributed under the terms and conditions of the Creative Commons Attribution (CC-BY) license (http://creativecommons.org/licenses/by/4.0/). 